\title{
RUDOLF SCHLECHTER'S SOUTH-AMERICAN ORCHIDS V. SCHLECHTER'S “NETWORK”: ECUADOR AND PERU
}

\author{
Carlos Ossenbach ${ }^{1,2,4} \&$ Rudolf JenNy ${ }^{3}$ \\ ${ }^{1}$ Orquideario 25 de mayo, Sabanilla de Montes de Oca, San José, Costa Rica \\ ${ }^{2}$ Jardín Botánico Lankester, Universidad de Costa Rica, Cartago, Costa Rica \\ ${ }^{3}$ Jany Renz Herbarium, Swiss Orchid Foundation, Basel, Switzerland \\ ${ }^{4}$ Corresponding author: cossenbach@opbarquitectos.com
}

\begin{abstract}
The fifth chapter of the series about Rudolf Schlechter's South-American orchids introduces us to those botanists and orchid collectors who travelled and worked in Ecuador and Peru and supplied Schlechter with many of the new orchid species he described. As in previous chapters, the biographies and accomplishments of these travellers are preceded by brief geographical and historical outlines for each of these countries. It is worth mentioning that the lives and orchids of such prominent figures in the orchidology of South America as F.C. Lehmann, W. Hennis, E. Bungeroth and E. Ule, who collected in Ecuador and Peru, have already been mentioned in previous chapters and are therefore omitted here.
\end{abstract}

Keywords/Palabras Clave: biography, biografía, history of botany, historia de la botánica, Orchidaceae

ECuADOR. Ecuador is divided geographically into three continental regions: the lowlands along the Pacific coast known as 'Costa', the mountain ranges of the Andes, known as the 'Sierra', and the eastern lowlands or 'Oriente', which form part of the Amazon River basin.

The Costa consists of lowlands, coastal mountains, and rolling hills that separate river valleys (Fig. 1). The Coastal Mountain Range, or Cordillera Costanera, elevations up to $1000 \mathrm{~m}$, divides the region into the Costa Externa, along the coast, and the Costa Interna, along the Andes. Guayaquil, the most important centre in the region, is Ecuador's second-largest city.

The Sierra consists of two mountain chains of the Andes, the Cordillera Occidental and the Cordillera Oriental, with an intermontane plateau where the main cities of Quito, the capital of the country, and Cuenca, Ecuador's third-largest city, are located. The Sierra has dozens of peaks that rise over $4200 \mathrm{~m}$, mostly of volcanic origin, including Mount Chimborazo, Ecuador's highest point at $6267 \mathrm{~m}$ (Fig. 2). The intermontane plateau lies at an altitude between 2000 and $3000 \mathrm{~m}$.

The Oriente stretches from the piedmont of the Andes to the lowlands along the borders of Peru and Colombia. In Schlechter's time mostly unexplored, the lowlands are crossed by large rivers which flow into the Amazon, among them the Río Napo (Fig. 3), Río Pastaza, Río Tigre, and Río Morona. For this reason, the region is also known as 'Amazonía'.
Over $1000 \mathrm{~km}$ west of the coast of Ecuador, we find the archipelago of the Galapagos, of volcanic origin. The largest island is Isabela, which is $120 \mathrm{~km}$ long. Santo Tomás, located on Isabela Island, is the highest peak of the Galápagos at $1490 \mathrm{~m}$ of elevation.

At the end of September 1791, the expedition to the Pacific of Alessandro Malaspina (1754-1810), an Italian seaman sailing under the Spanish flag, after rounding Cape Horn and visiting Chile and Peru, disembarked in Guayaquil,Ecuador's main port on the Pacific coast (Fig. 4). The French botanist Louis Neé (1734-1807) was part of the expedition as a botanist. From his collections of plants, we have a species of Caularthron (= Diacrium), beautifully illustrated by one of Malaspina's draftsmen, José Guío. It is, to our knowledge, the first illustration in Ecuador's orchid history: it is now preserved in the archives of Madrid's Royal Botanical Garden (Fig. 5). Malaspina's expedition to the Pacific would open the way to numerous explorers and travellers who would visit Ecuador in the century before Rudolf Schlechter's appearance on the scene.

Eight years after the arrival of the Malaspina expedition, Juan José Tafalla (1755-1811), a member of Hipólito Ruiz and José Pavón's expedition to Peru and Chile, received the order to proceed from Lima to Guayaquil, on Ecuador's Pacific coast. Tafalla, in the company of his assistant Juan Agustín Manzanilla and a draftsman, arrived in Guayaquil on September 28 1799, where the party 


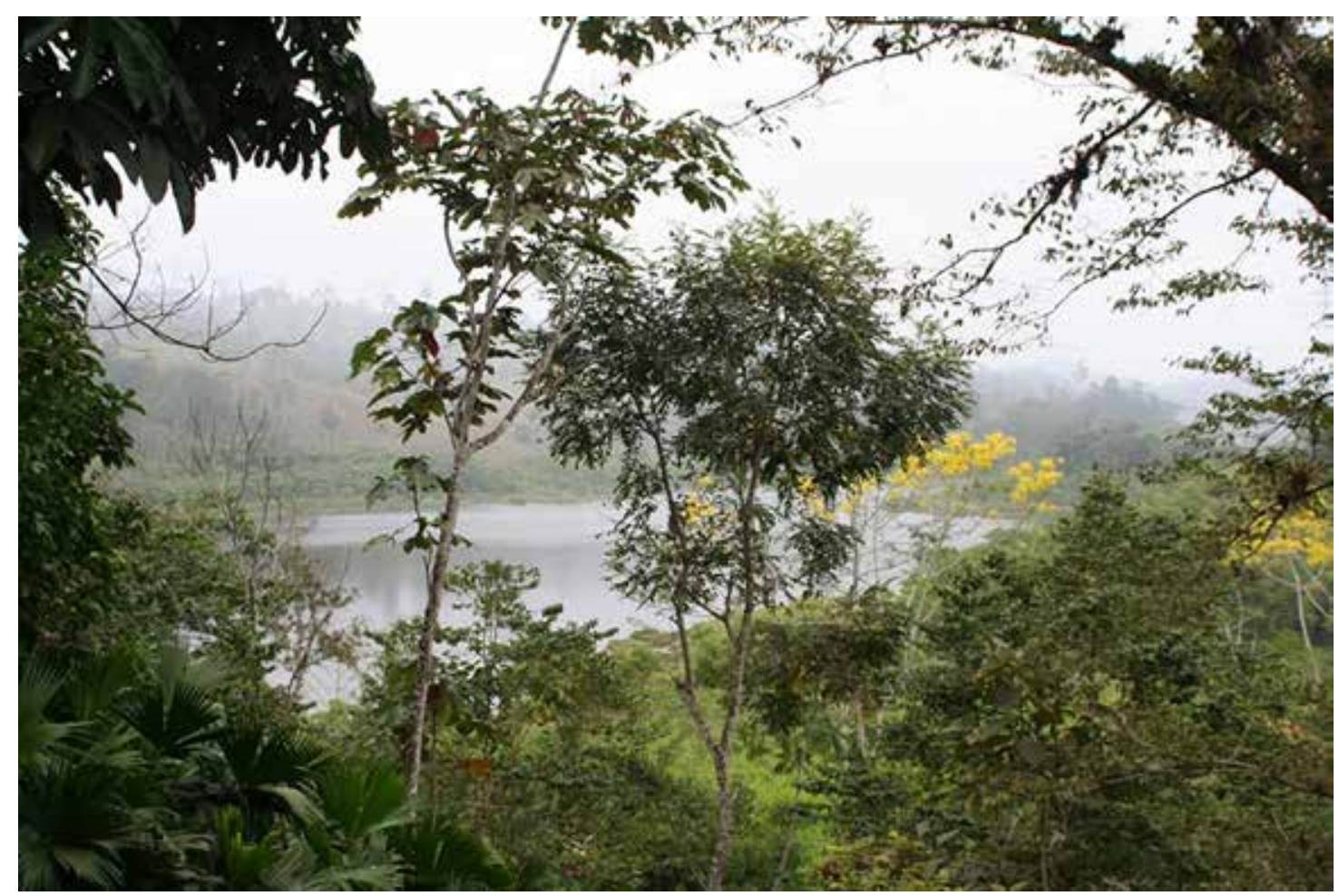

FIGURE 1. Lagoon of Cube, in the province of Esmeraldas - Ecuador's coastal region. Unknown photographer.

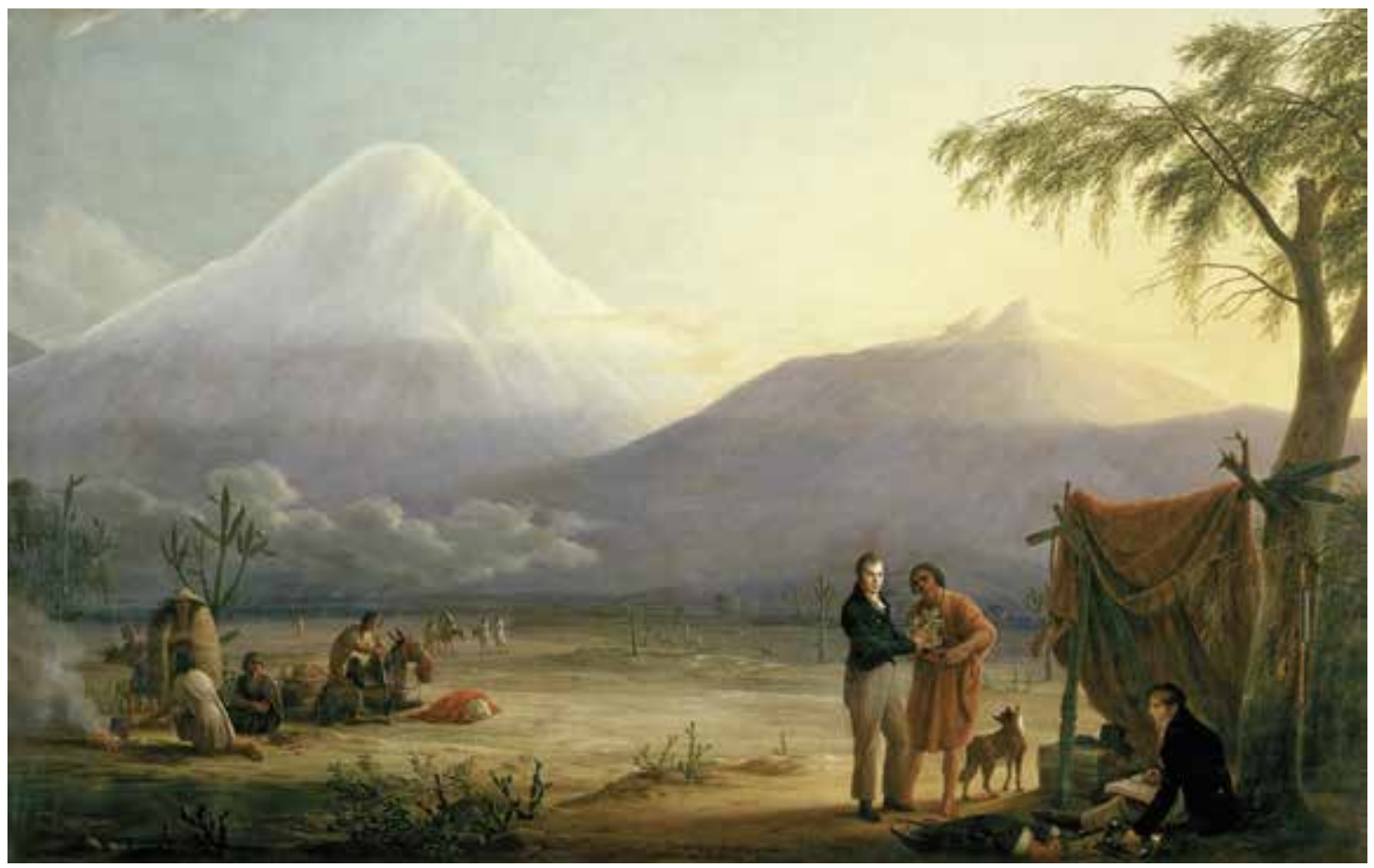

FigURE 2. Humboldt and Bonpland at the foot of mount Chimborazo. Oil on canvas by F.G. Weitsch. 


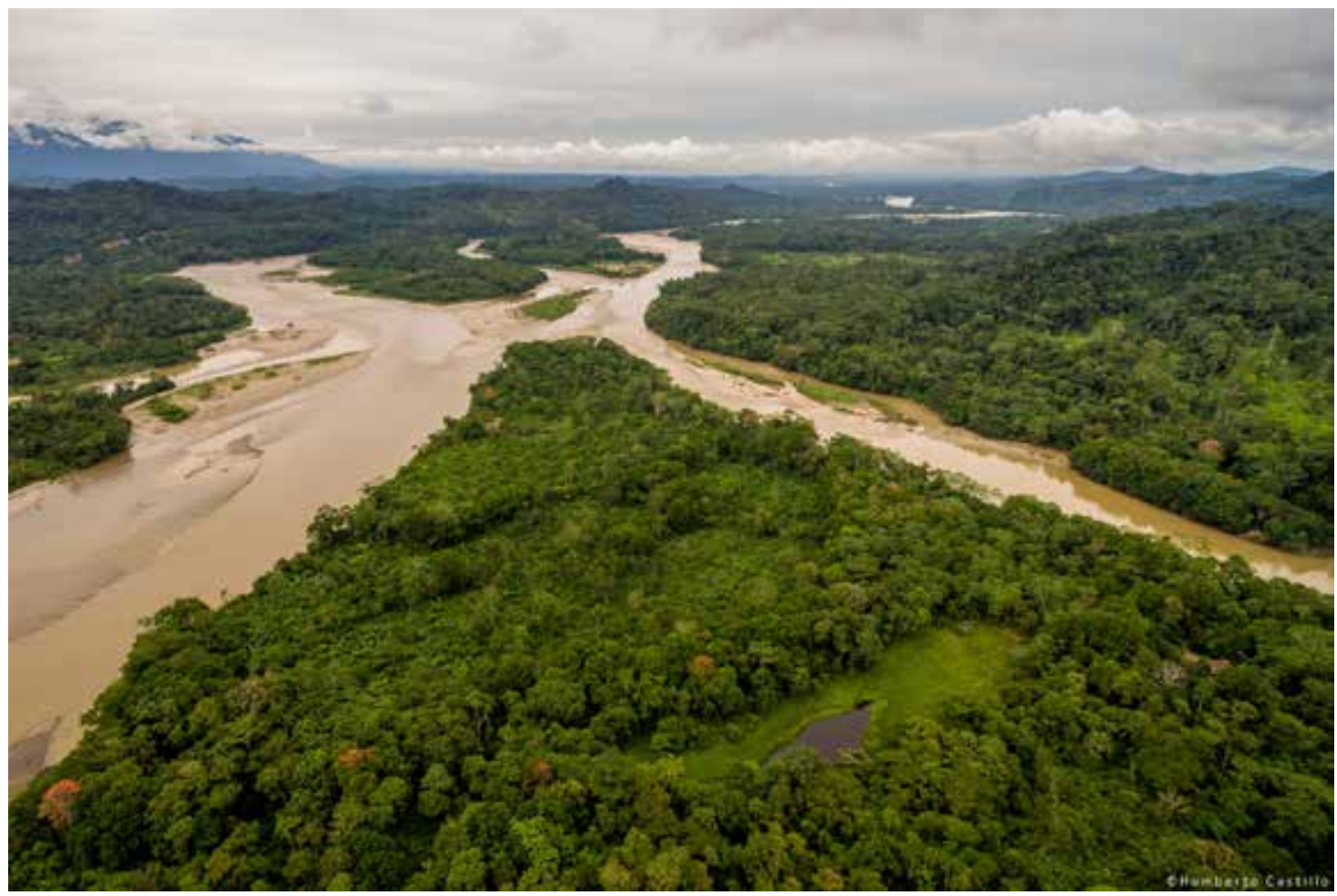

Figure 3. Confluence of rivers Napo and Arajuno, in Ecuador's eastern plains. Photograph by Humberto Castillo

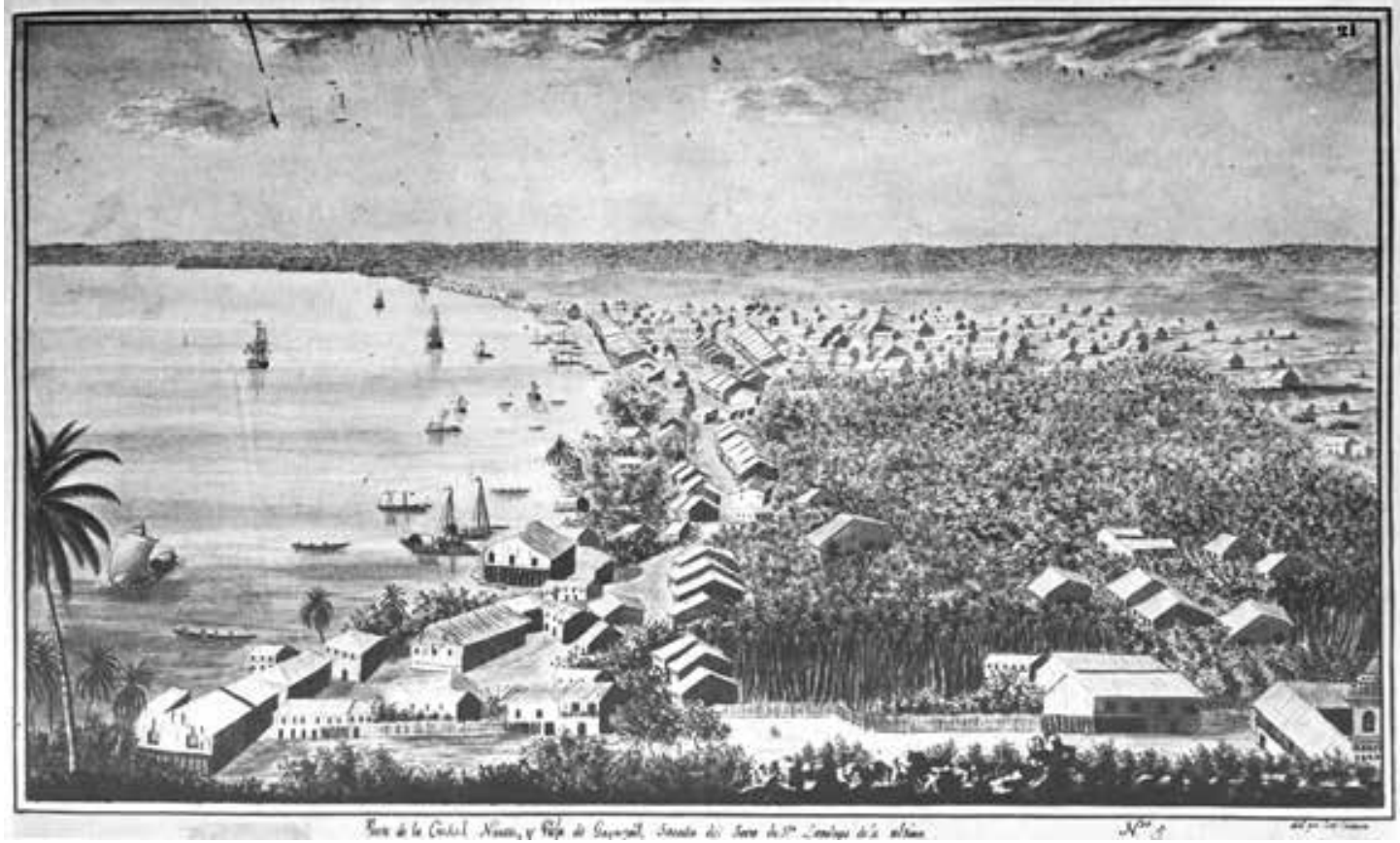

Figure 4. View of Guayaquil in 1791. By José Cardero, draftsman of Malaspina's expedition. Courtesy of the Royal Botanical Garden, Madrid. 


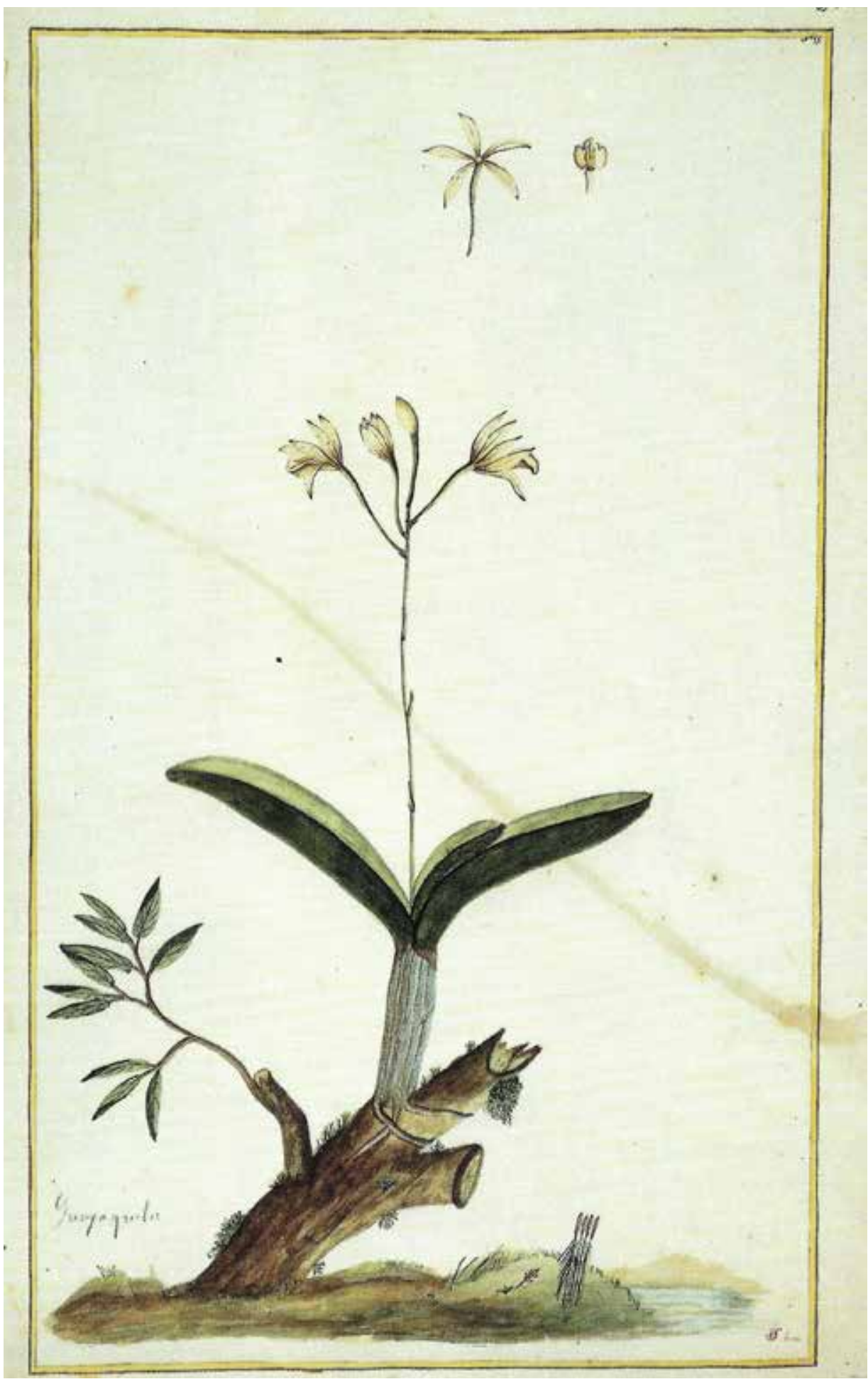

FIgUre 5. Caularthron sp. by José Guío. Collected by Louis Neé during Alessandro Malaspina's expedition. Courtesy of the Royal Botanical Garden, Madrid. 


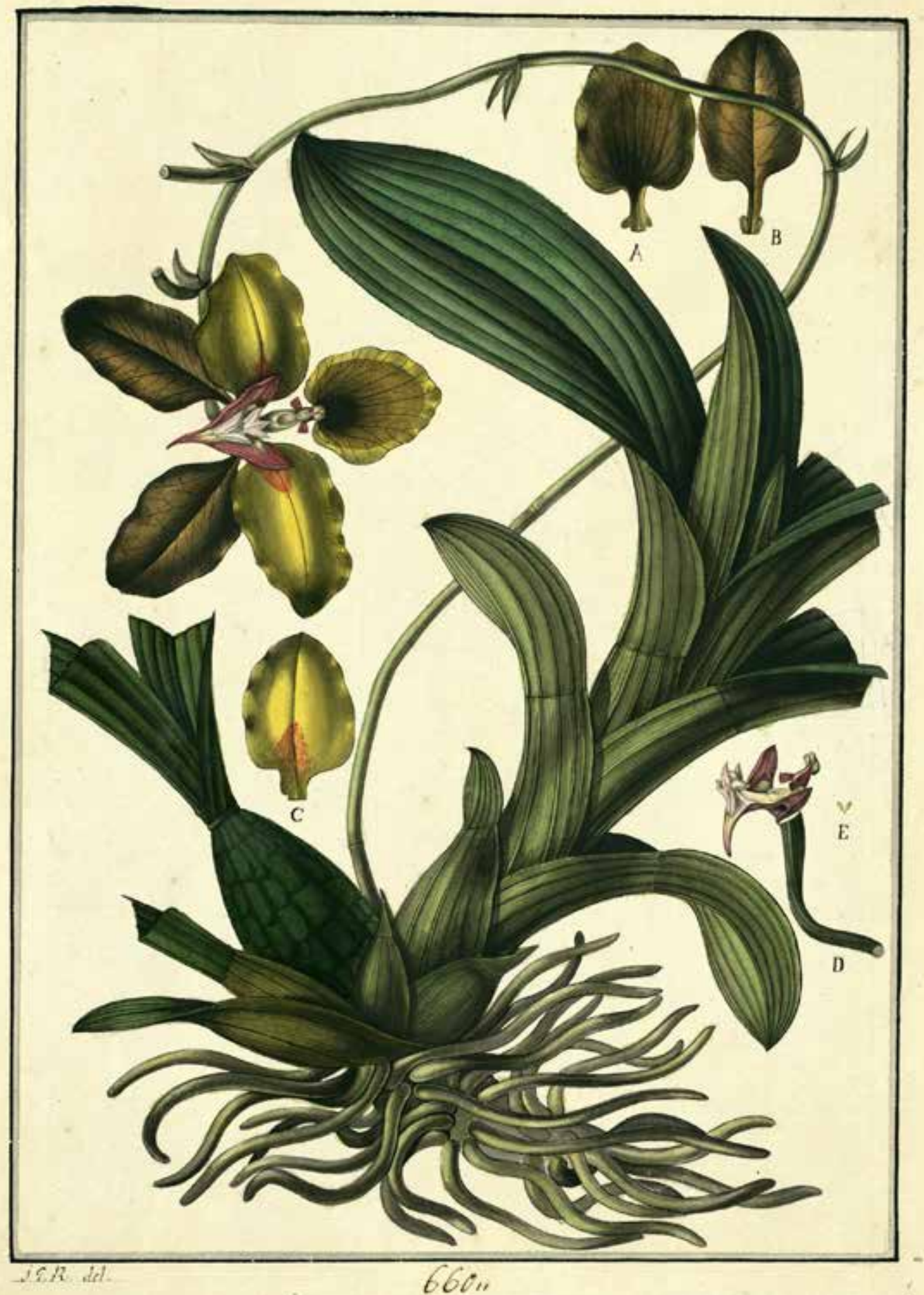

FIGURE 6. Cyrtochilum macranthum (Lindl.) Kränzl. Illustration by José Gabriel Rivera. Courtesy of the Royal Botanical Garden, Madrid. 


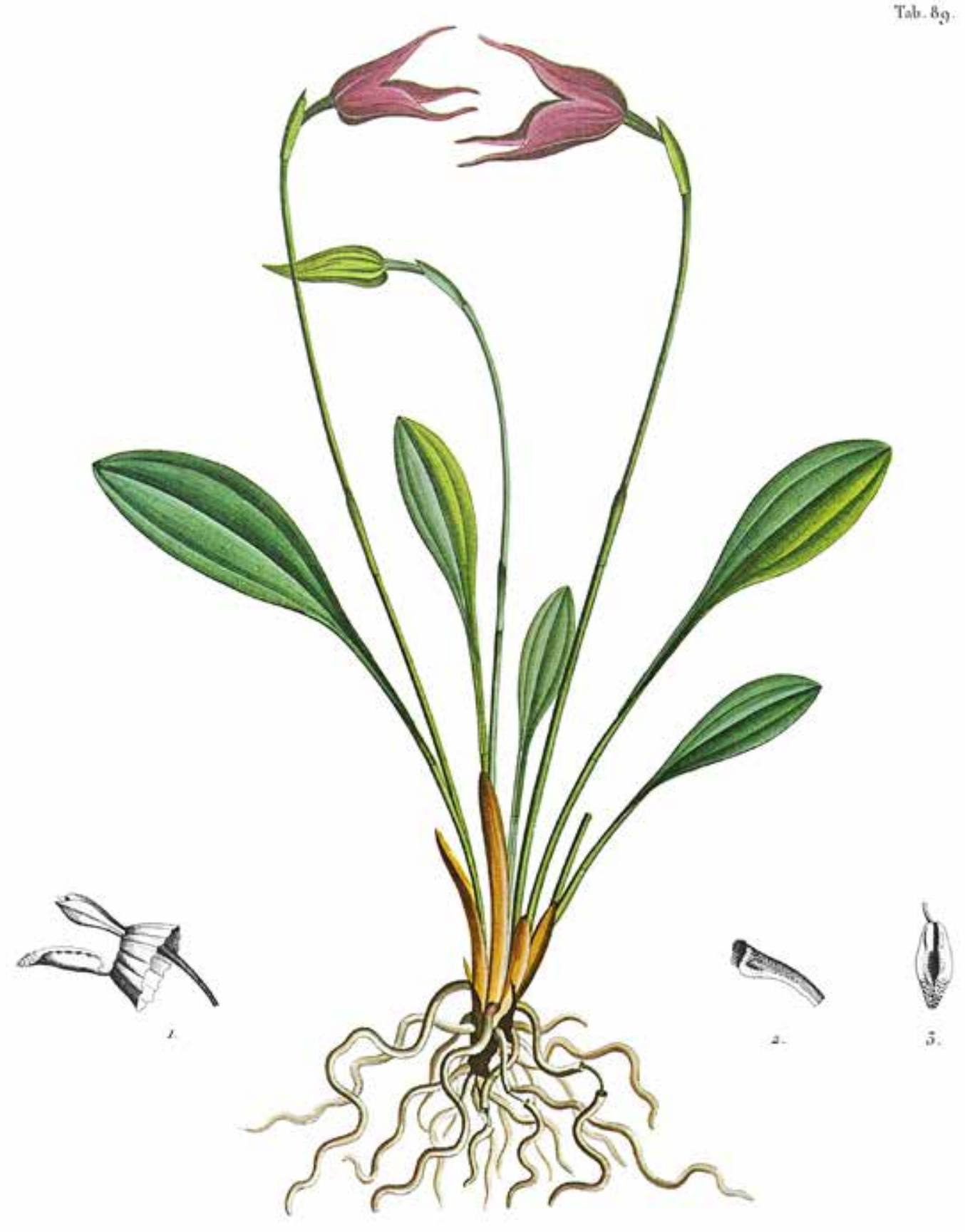

ropor anderet

MASDEVALIIA unitora.

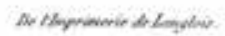

FIGURE 7. Masdevallia uniflora Kunth (= Masdevallia bonplandii Rchb.f.), collected by Humboldt and Bonpland in Ibarra, Ecuador. Nova Genera et Species Plantarum, vol. I, plate LXXXIX. 


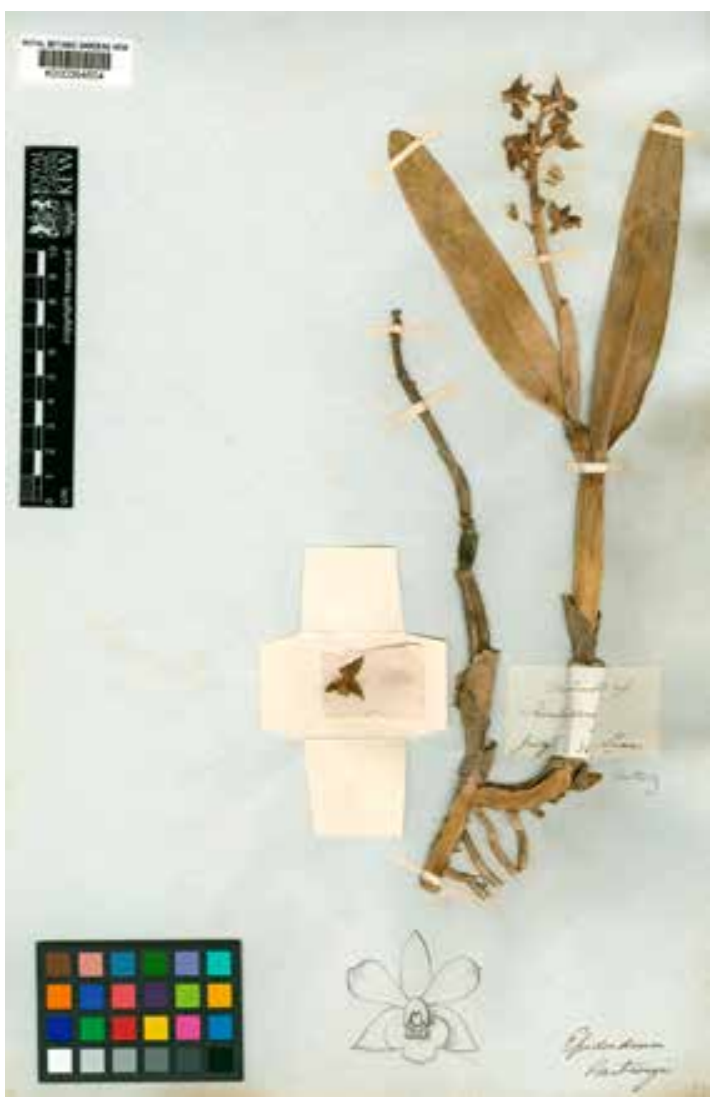

FIGURE 8. Holotype of Prosthechea hartwegii (Lindl.)

W.E.Higgins, collected near Loja, in the Cordillera. Courtesy of Kew Herbarium \# K000364654.

would botanize for the next four years. Tafalla was the author of the famous Flora huayaquilensis, a great work that would unfortunately not be published until 1989-1991 by the Royal Botanical Garden in Madrid (Ossenbach 2020: 244). It contained not less than 290 beautiful illustrations, of which five were of orchids (Fig. 6).

Alexander von Humboldt (1769-1859) and Aimé Bonpland (1773-1858), on their long journey across northern South America, crossed the border between Colombia and Ecuador in December 1801 and arrived in Quito in the following January; the city would be their headquarters until August 1802, when they continued their journey to Peru. From Quito, they organized numerous excursions, climbing to the heights of the Chimborazo and the Pichincha volcanoes. According to Schlechter, their botanical collections, especially those of Orchidaceae, will always be the basis for our knowledge of the Ecuadorian flora. Then, Humboldt

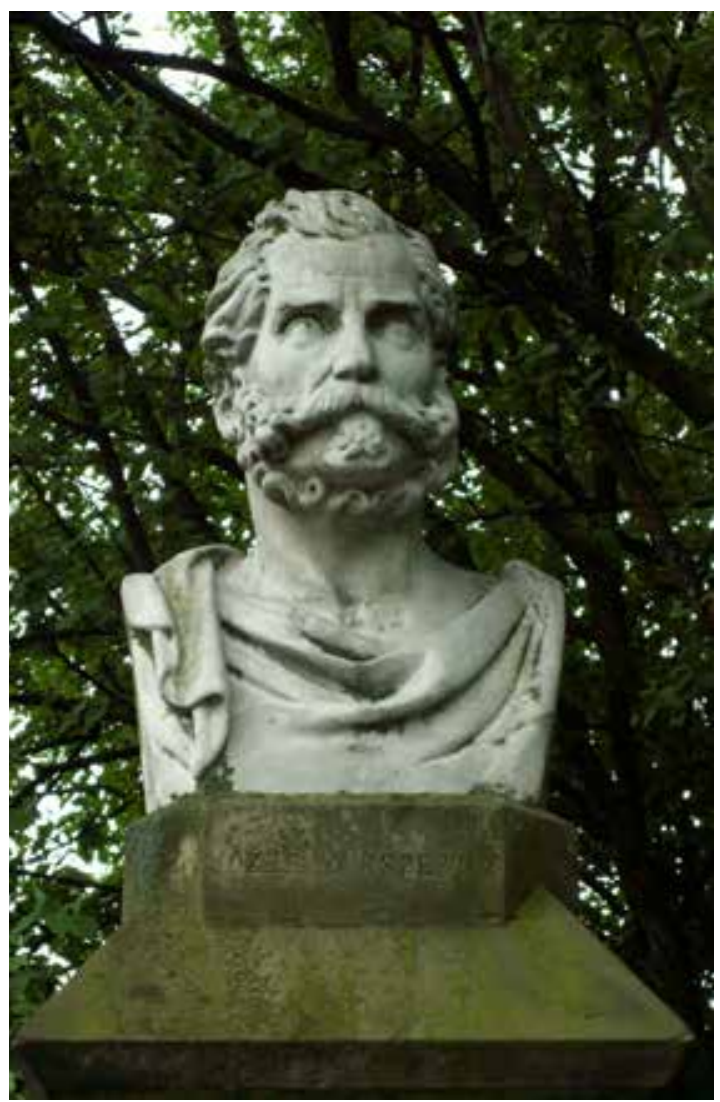

Figure 9. Bust of Josef Ritter von Rawiez Warscewicz (1812-1866) at the Cracow Botanic Garden. Unknown photographer.

and Bonpland travelled on to Peru and sailed from the port of Callao to Guayaquil. Here, they met Tafalla and went in his company on several botanical excursions. In Guayaquil, Humboldt wrote the manuscript of the first scientific document of his long expedition, Essai sur la géographie des plantes, which would be published upon his return to Europe (Humboldt \& Bonpland 1805).

The majority of the orchids collected during Humboldt and Bonpland's journey were published in 1815 in the first volume of their Nova Genera et Species Plantarum, a work they co-authored with Carl Sigismund Kunth. It contained a total of 24 illustrations of orchids, all by Pierre Jean François Turpin (1775-1849), considered one of the greatest floral and botanical illustrators of the Napoleonic era (Ossenbach 2020: 328) (Fig. 7).

William Jameson (1791-1873), a Scot by birth, arrived in Guayaquil in 1822 and lived in Ecuador for the rest of his life. He was appointed Professor of Chemistry 


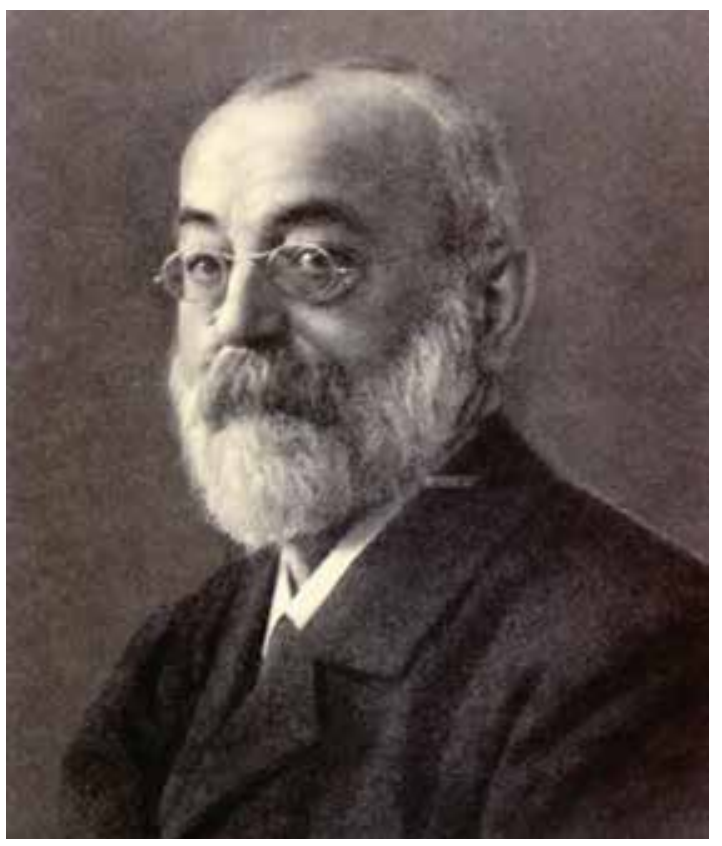

Figure 10. Franz Theodor Wolf (1841-1924). Archives of Rudolf Jenny.

and Botany at the Central University of Ecuador in Quito and was one of the most prolific orchid collectors of his time. Dozens of his orchid specimens were described as new to science, and a number of them named in his honor. Jameson -at different periods of his life- was acquainted with other important orchid collectors who worked in Ecuador. Years later, the famous plant collector and traveller Richard Spruce (1817-1893) was in Ecuador between 1857 and 1863 . He had only words of praise for Jameson: "one of the most amiable of men, an ardent collector [...] and a very fair botanist and mineralogist" (in a letter to Daniel Hanbury from 1866) (Spruce 1908: 342).

Francis Hall (1791-1833), a British officer who fought in Ecuador's war of independence against Spain, and was murdered in 1833, collected many new orchid species described mainly by Lindley. Jameson wrote of him as the "only person in this part of the world for whom I had formed a sincere attachment" (in a letter to William Hooker) (Hooker 1835: 79).

Carl Theodor Hartweg (1812-1871), a German collector for the Royal Horticultural Society, arrived in Guayaquil early in 1841, after collecting in Mexico and Guatemala between 1836 and 1840. Hartweg made his way from Guayaquil to Loja, near the Peruvian border, and then rode northwards to Cuenca and Quito until, at the end of the year, he crossed into Colombia to continue his botanical collections. Hartweg's Mexican and Central American orchids were described mainly by Lindley in Plantae hartwegianae (Bentham 1839) (Fig. 8).

Josef Ritter von Rawiez Warscewicz (1812-1866), a Pole who collected orchids mostly for Reichenbach, seems to have spent only a few months in Ecuador, traversing the country from Loja in the south to the border with Colombia in the north in 1851 and 1852. Many orchids were named after him, among them the new genus Warszewiczella Rchb.f. A recurrence of yellow fever in 1853 compelled Warscewicz to return to Poland, where he became supervisor of the Botanical Gardens in Cracow. He retained this position until his death (Fig. 9).

Moritz Wagner (1813-1887) visited Ecuador between 1858 and 1859. Although his main interest was geology, he also gathered an important botanical and zoological collection. His botanical specimens, among them many orchids, are kept at the Botanical Museum in Munich. Schlechter, however, complained because he did not find any novelties among Wagner's collections.

Franz Theodor Wolf (1841-1924; Geologist and botanist in Ecuador 1870-1891)

Franz Theodor Wolf (Fig. 10) was born in the German village of Barthlomä, the third of the seven children of a schoolteacher. As a young man of 16, he became a member of the Jesuit order and studied theology. From 1862 he took courses in natural sciences at the University of Bonn but interrupted his studies in 1864 when he was called to work as a teaching assistant at the Jesuit abbey of Maria Laach.

It was in 1866, while in Maria Laach, that Wolf occupied himself for the first time with orchids and published an article under the title Beitrage zur Enwicklungsgeschichte der Orchideen-Blüthe (=Contributions to the history of the evolution of the orchid flower), which has several interesting illustrations with flower analysis of different orchid genera (Fig. 11).

In 1870, the year of his ordination as a priest, he was appointed professor of geology and mineralogy at the recently founded Polytechnical School in Quito, where he found his strong pro-Darwin scientific opinions to conflict with his religious beliefs. After his fellow Jesuits accused him of neglecting his duties as a priest, Wolf left the Jesuit order in 1874 and had to 


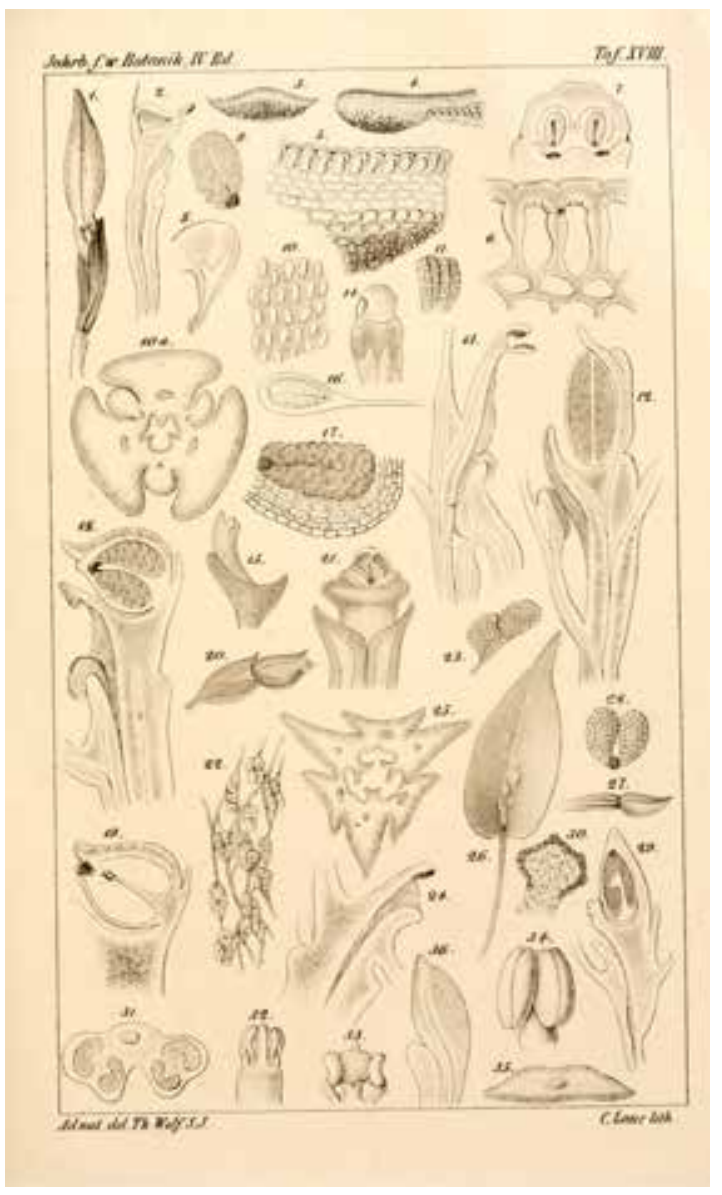

FIGURE 11. Plate XVIII of Wolf's work which includes three tropical American orchids: 1-10a: Trichopilia suavis, 20-25: Coelia macrostachya and 26-28: Pleurothallis tridentata.

take leave from his post at the University. However, his decision to return to secular life might have had other, more mundane reasons: barely a year later, he married a beautiful 13-year-old Ecuadorian girl named Jacinta Pasaguay, with whom he had seven children.

When he lost his government salary, he sought private commissions, surveying private estates and producing a new city plan of Guayaquil. Wolf travelled to the Galápagos archipelago in 1875 and described its flora. Wolf Island, remote from the main island group and with no permanent population, and Wolf volcano (Fig. 12) on the main island of Isabella, were named after him. Unfortunately, only nine specimens remain from his botanical collections as most of his plants were lost in storage in Guayaquil.
At his return from the islands, Wolf was named "Official Geologist of Ecuador" by the President of Ecuador. He went back to Germany in 1891 and published his main work, Geografía y Geología del Ecuador (Wolf 1892), probably the best description of a South American country in the $19^{\text {th }}$ century.

Friedrich Carl Lehmann described two species of Coryanthes in 1891. He wrote: "The first, Coryanthes wolfi (Fig. 13-14), was named by me in honour of Professor Dr. Wolf, formerly of Guayaquil, now of Dresden. Dr. Wolf will shortly favour the world with a reliable map of the physical phenomena of Ecuador. In his house, I had the pleasure of seeing, examining, and sketching the first flowers of this marvelous plant. However, it was known to me many years previously as an Ecuadorean species" (Lehmann 1891: 483).

Rudolf Schlechter, in his Orchideenflora von Ecuador (1921), described a new orchid species as Pleurothallis wolfiana (Fig. 15) and wrote: "I dedicate this species to Mr. Theodor Wolf, the most knowledgeable man about Ecuador's Andean regions" (Schlechter 1921: 65).

Luigi (Luis or Aloysius) de Sodiro (1836-1909; collected 1876-1907)

Luigi Sodiro (Fig. 16) was born in Muzzolon, in the community of Cornedo in the Italian province of Vicenza. Still a young man, he entered the order of the Jesuits and began his career as a professor of Natural Sciences at the College of Ragusa. Sodiro undertook botanical excursions in his native Italy and neighbouring Dalmatia, Austria, and Switzerland. There he gained the knowledge and experience which prepared him for his life-long work (Porter 1909: 47). "It was the Jesuits that sent him to the Republic of Ecuador, and fortune could not have taken him to a better place to find food and incentives for his tireless work" (Briosi 1914: iv).

"With the work of (William) Jameson and his publication of Synopsis Plantarum Equatoriensium in 1865 and with the arrival of (Father) Luigi Sodiro in 1870 with his great and intense collections, it can be said that the second half of the past century constitutes the golden age of Ecuadorian botany" (Acosta-Solís 1968: 36). Luis Sodiro, in his publications, used the Italian form of his name, Luigi, as well as the Spanish and Latin versions: Luis and Aloysius. 


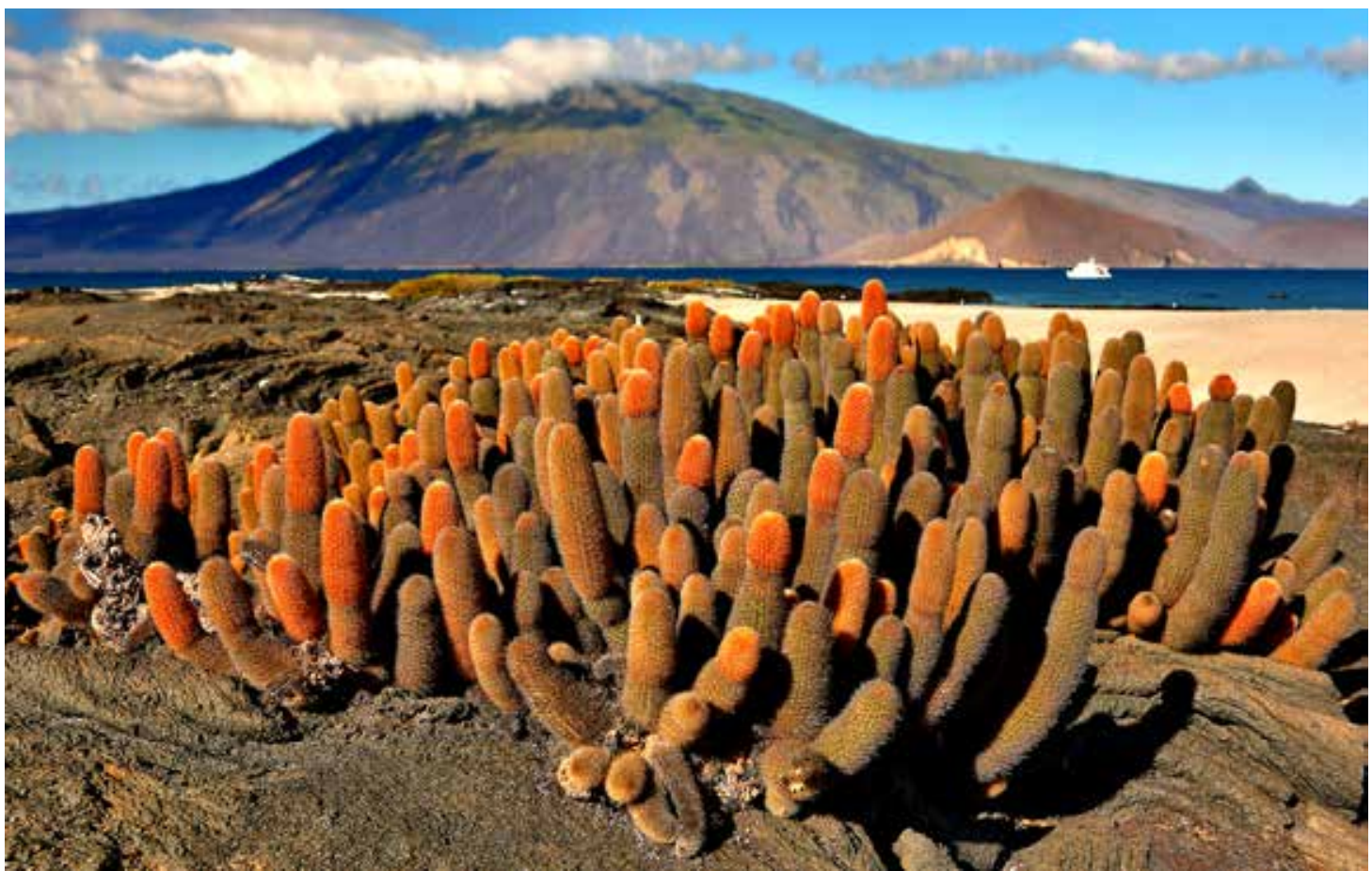

FIGURE 12. Wolf volcano on Isabela island, Galápagos. Photograph by Viri Vondrak.

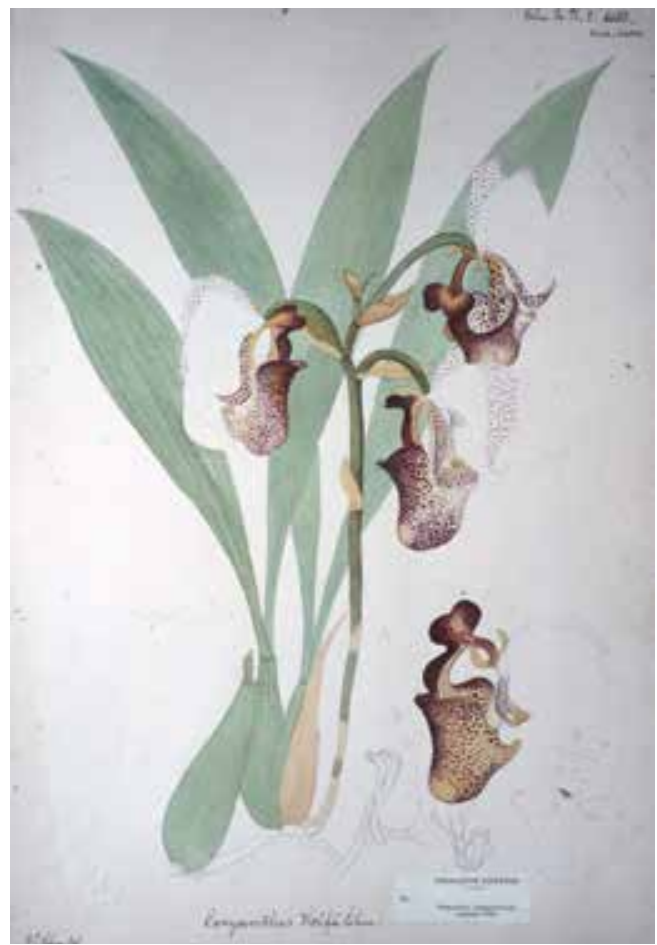

FIGURE 13. Coryanthes wolfii F.Lehm. Sketch by F.C.Lehmann made at Wolf's house. Courtesy of the Kew herbarium.

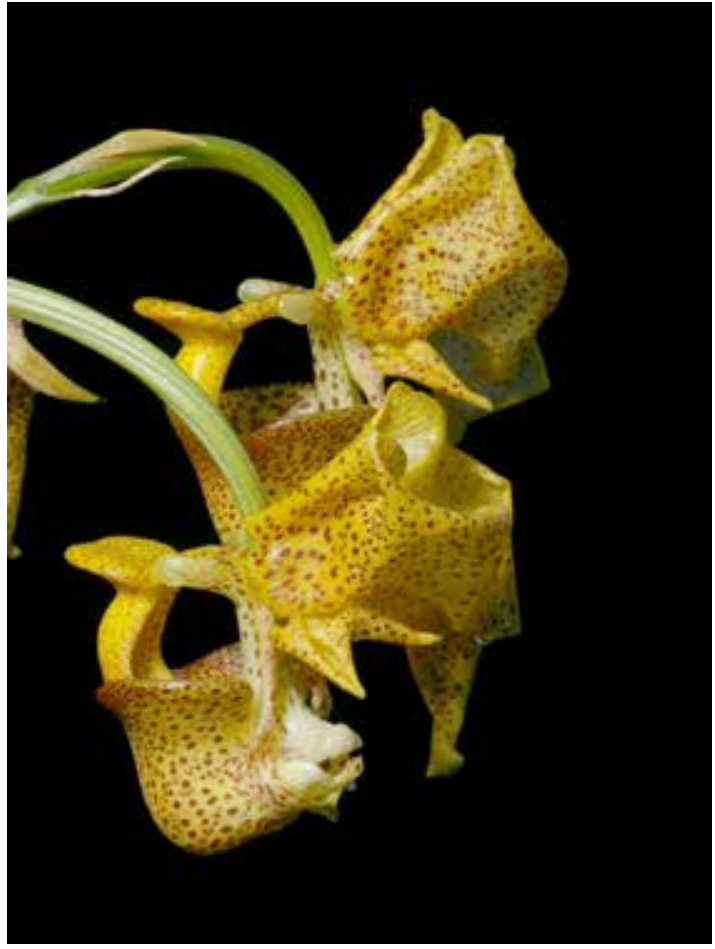

FIGURE 14. Coryanthes wolfii F.Lehm. as C. elegantium Linden \& Rchb.f. Photograph by Günter Gerlach. 


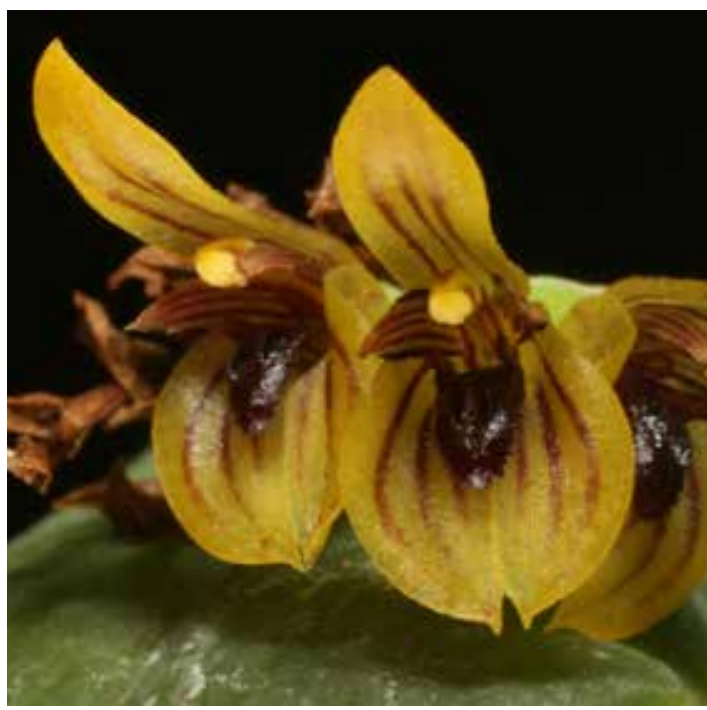

FIgure 15. Pleurothallis wolfiana Schltr. as Acianthera sicaria (Lindl.) Pridgeon \& M.W. Chase. Photograph by Duane McDowell.

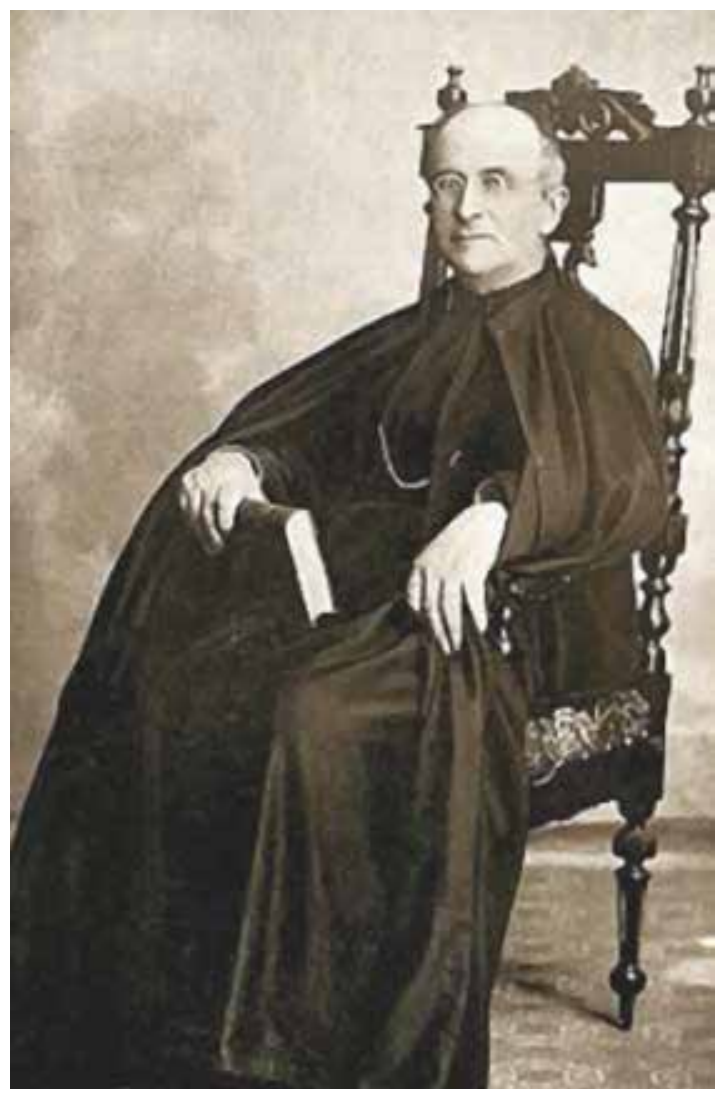

FIGURE 16. Father Luigi Sodiro (1836-1909). Unknown photographer.
Sodiro established himself in Quito (Fig. 17), where he was appointed professor of Botany at the University in 1870; he also founded the University Botanical Garden. Until he died in 1909, he would explore the plant life on the high mountains in the province of Quito, such as the volcanoes Corazón and Pichincha (Baldini \& Guglielmone 2012: 14).

"The rich collections of Sodiro were kept in his herbarium (Fig. 18) at the College of San Gabriel de Quito, and were administered by his successor, Father L. Mille (1873-1954), I have news that a great part of this herbarium was sold to C.M. Hicken, of the Darwinion Institute of the Republic of Argentina. This commercial transaction represented a great loss for the Ecuadorian science" (Acosta-Solís 1968: 37).

A very significant collection of orchids was made by Sodiro and sent for botanical description to Alfred Cogniaux in Belgium. However, the Belgian botanist feared he would not be able to cope with the work, so in 1904 called on Rudolf Schlechter, who determined most of Sodiro's plants and Louis Mille's plants (see later). Schlechter described them partly in his Additamenta ad Orchideologiam ecuadorensem I-III (Schlechter 19141916, 1917-1919) and finally in his Orchideenflora von Ecuador (Schlechter 1921).

Sodiro's specimens were destroyed during the bombing of the Berlin Museum during WWII. Fortunately, many photographs and drawings were prepared before the war and are kept today at the Oakes Ames Orchid Herbarium at Harvard University (Fig. 19).

In addition, Schlechter dedicated 19 species and a new genus (Fig. 20) to Sodiro: 16 with the epithet sodiroi and three others named aloisii. These are listed here under Schlechter's basionym names: Camaridium sodiroi, Dichaea sodiroi (Fig. 21), Diothonea sodiroi, Elleanthus sodiroi (Fig. 22), Epidendrum aloisii, Epidendrum sodiroi, Gomphichis sodiroi, Govenia sodiroi, Habenaria sodiroi, Masdevallia sodiroi (today a synonym of Dracula sodiroi) (Fig. 23), Microstylis sodiroi, Odontoglossum sodiroi, Oncidium aloisii, O. sodiroi, Pelexia sodiroi, Pleurothallis aloisii, P. sodiroi, Stelis sodiroi and Stenorrhynchos sodiroi.

Henrik Franz Alexander von Eggers (1844-1903; collected 1893-1897)

Towards the end of April 2020, don Gonzalo González Cabal (Fig. 24) told a story to a reporter 


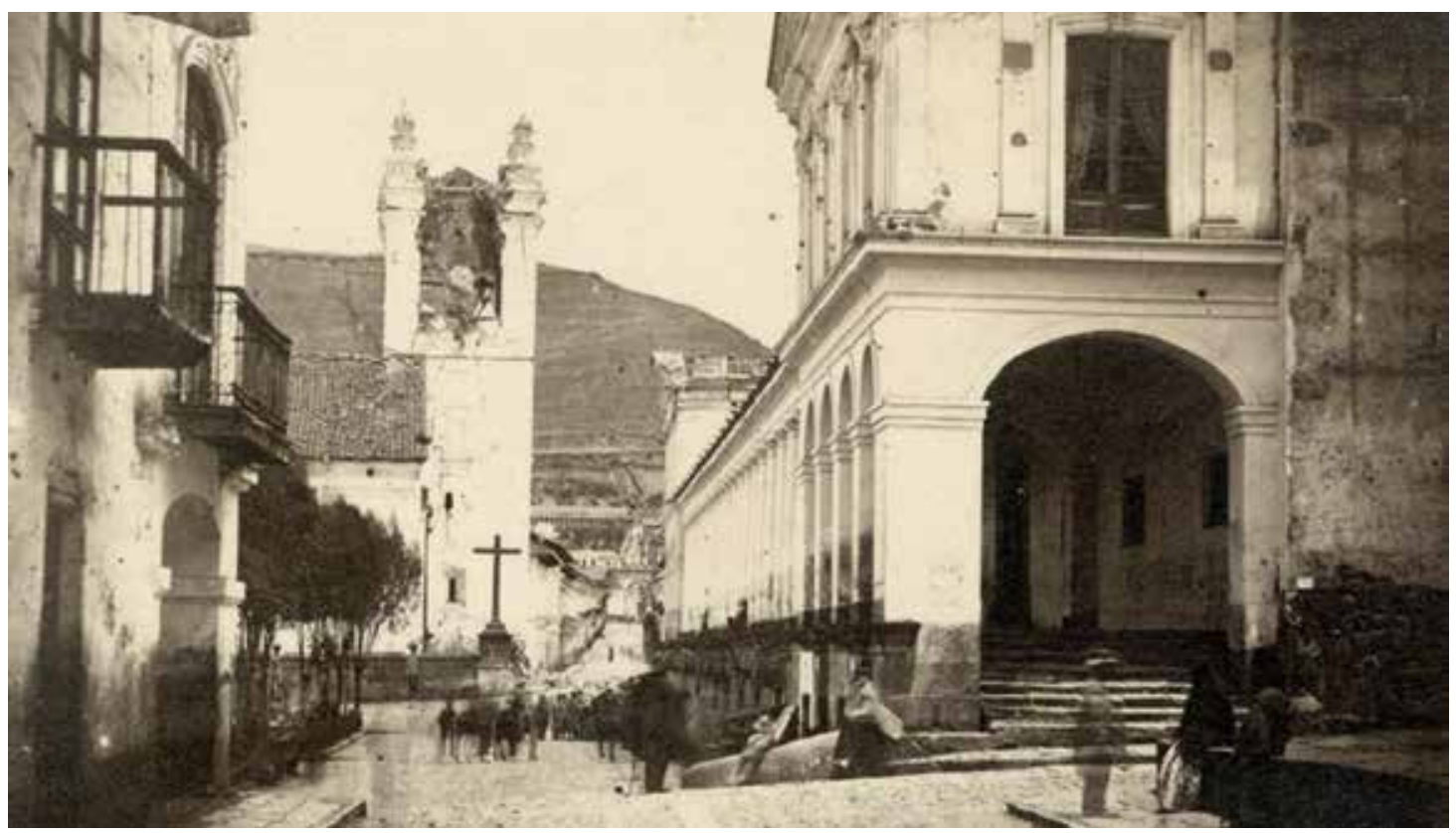

FIGURE 17. Independence Place in Quito, 1870. Unknown photographer.

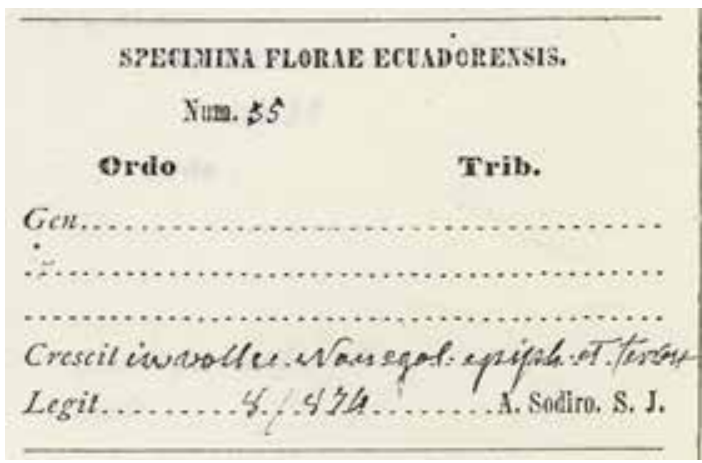

FIGURE 18. Sodiro's herbarium label. Courtesy of Harvard University Herbaria \#00099031

from the journal La Revista, published by the newspaper group El Universo in Guayaquil Ecuador. As he recalled, he was walking one day through a forest in his "hacienda" El Recreo, in the province of Manabí, in Ecuador's coastal region, when he found a beautiful small plant whose flowers shone brightly white. Fascinated, he took a photograph of it and put it on the Facebook page of the hacienda.

A few weeks later, don Gonzalo was contacted by the New York Botanical Garden. He was told that it was the first time that anybody had seen a picture of Steriphoma urbanii (Fig. 25), a plant which was only known from the type specimen collected and described as a new

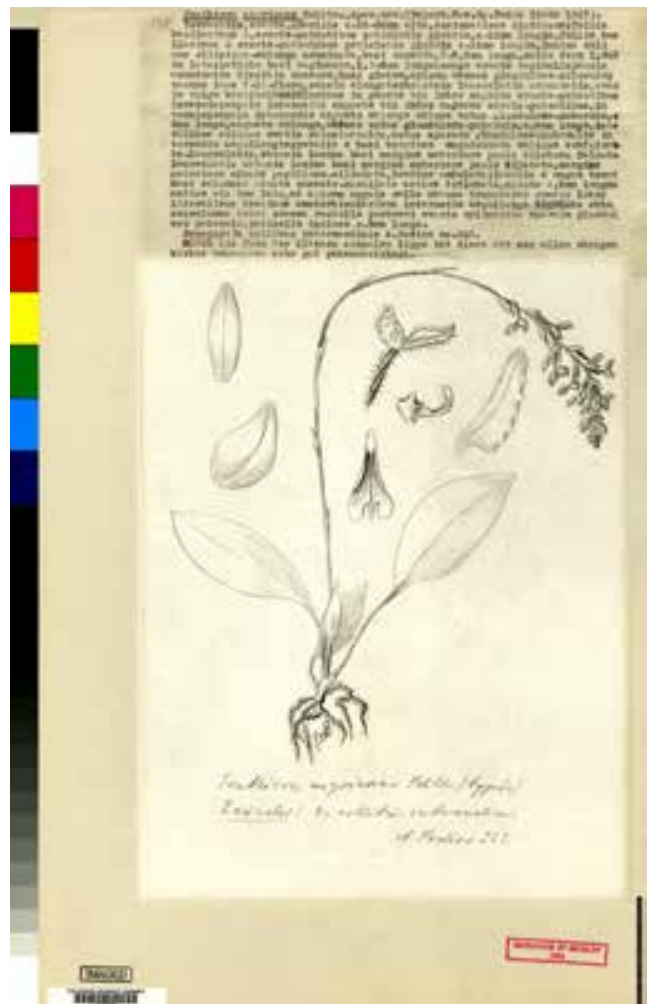

FIGURE 19. Schlechter's description and drawing of type of Ponthieva nigricans Schltr. (collected by Sodiro). Courtesy of Harvard University Herbaria \#00103550. 


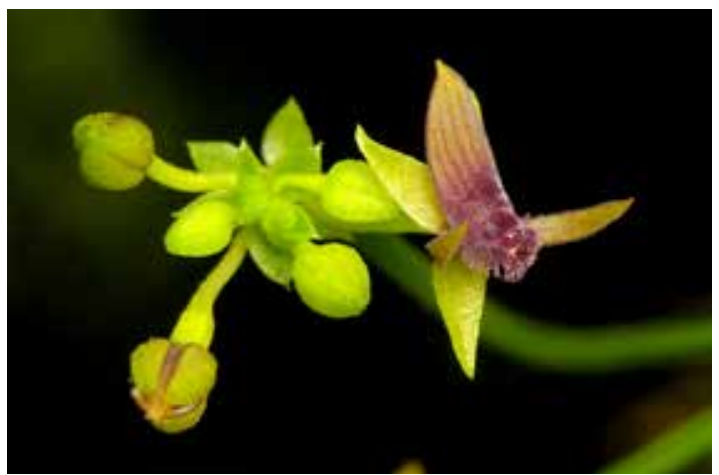

FIgure 20. Sodiroella ecuadorensis Schltr. (= Telipogon selbyanus N.H.Williams \& Dressler. Photograph by Andreas Kay.

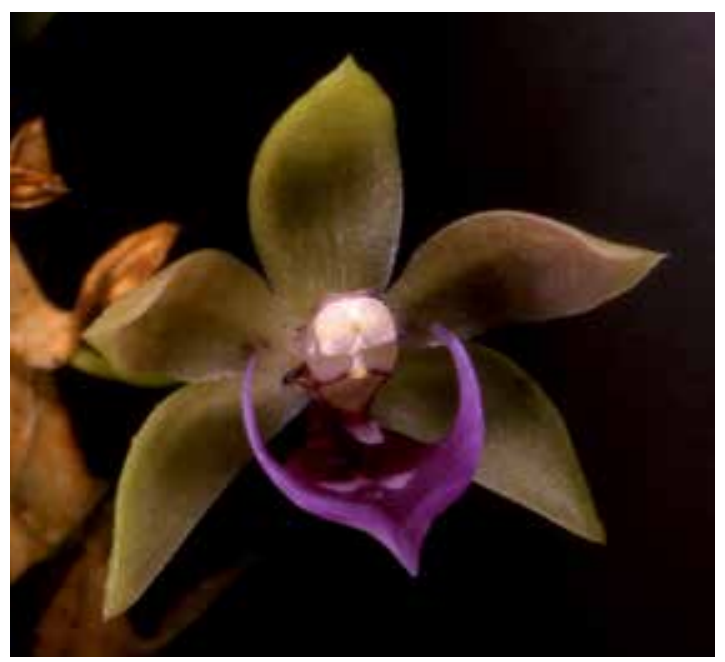

Figure 21. Dichaea sodiroi Schltr. Photograph by Orchi.

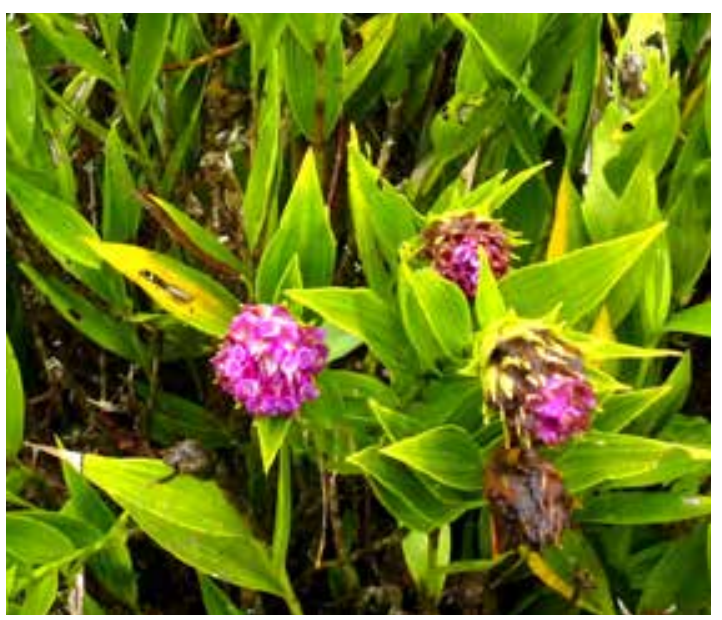

FIGURE 22. Elleanthus sodiroi Schltr. Photograph by Andreas Kay.

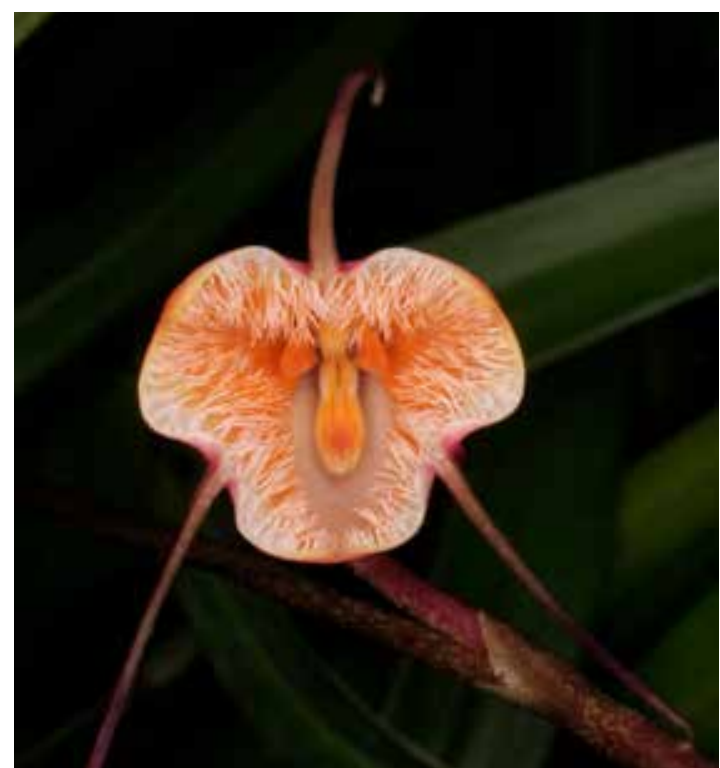

FIgURE 23. Draula sodiroi (Schltr.) Luer. Archives of Rudolf Jenny

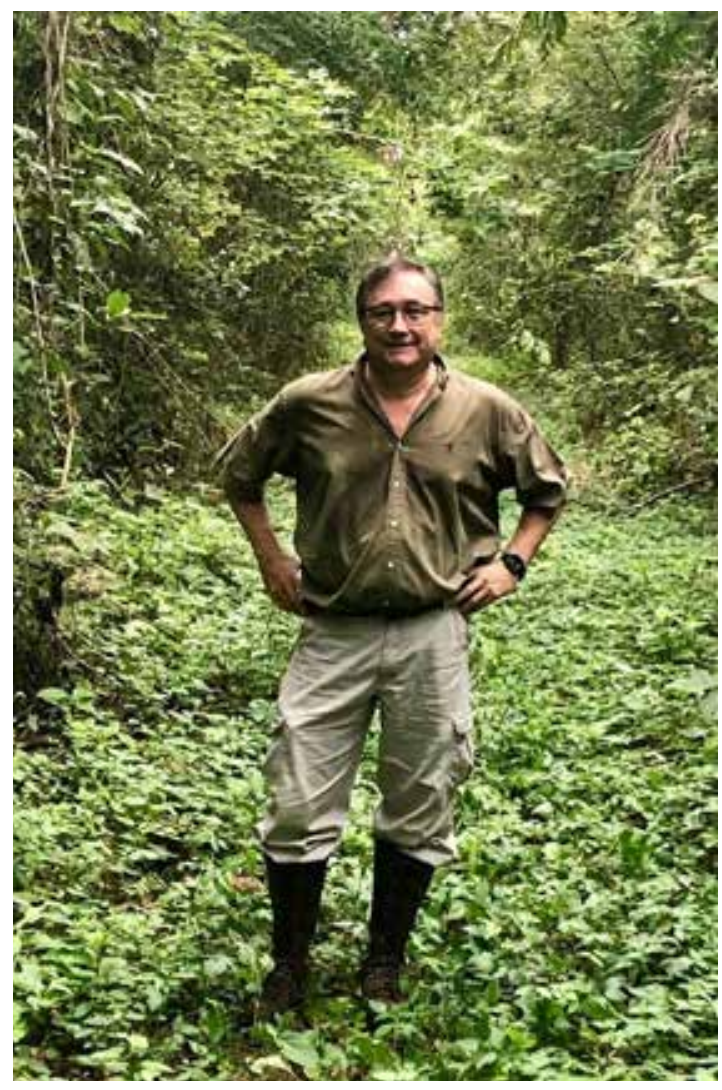

Figure 24. Don Gonzalo González Cabal, photographed in his Hacienda el Recreo.

LANKESTERIANA 21(2). 2021. (C) Universidad de Costa Rica, 2021. 


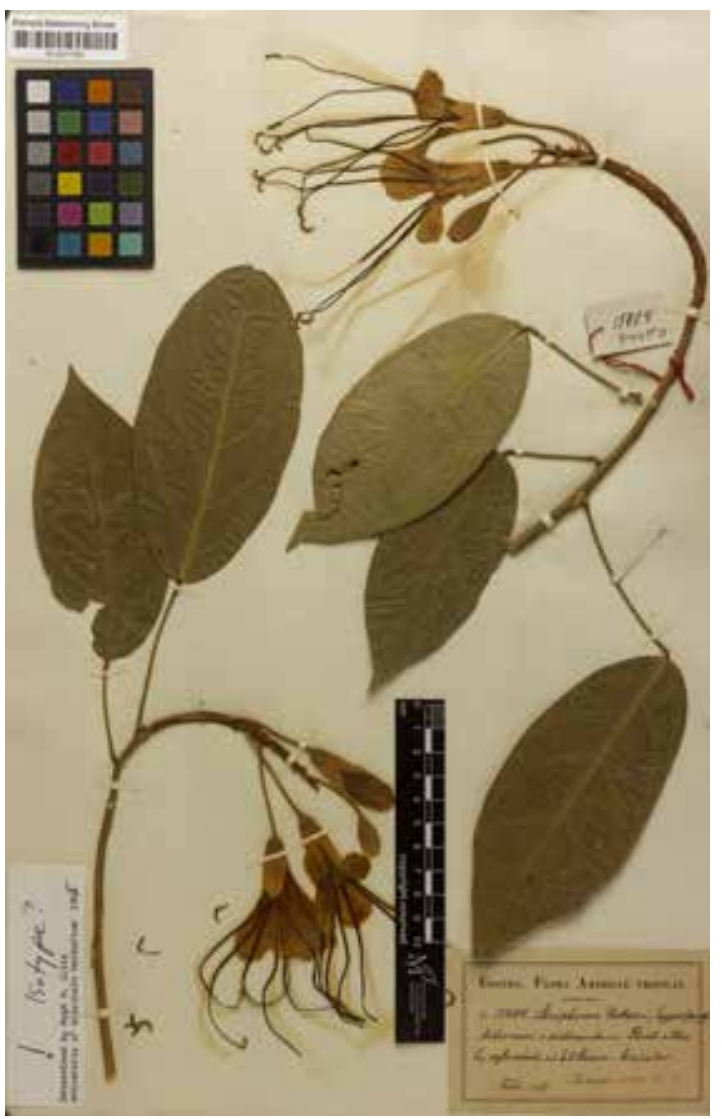

FIGURE 25. Isotype of Sterophoma urbanii Eggers. Courtesy of Munich Botanical Garden.

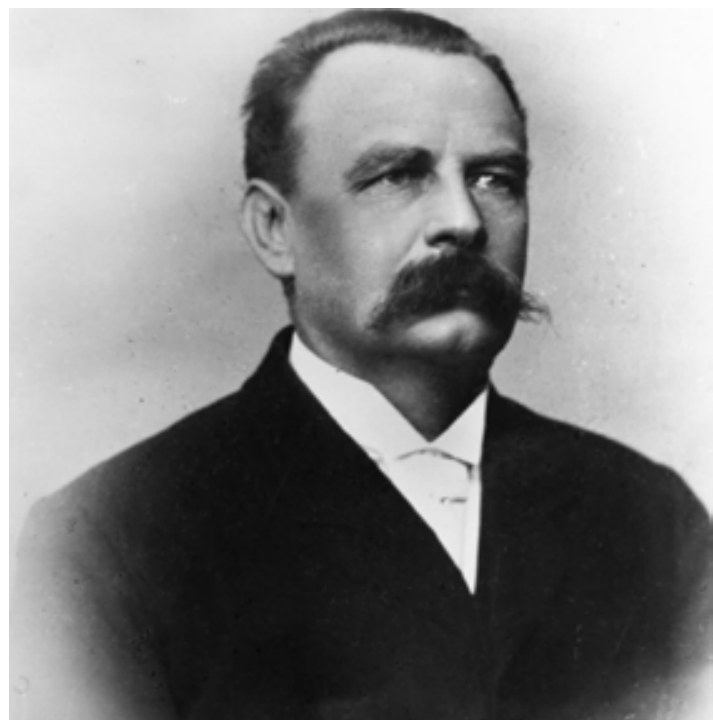

Figure 26. Henrik Franz Alexander von Eggers (18441903). From Virgin Island Daily News, 2 August 2016. species in 1897 by Henrik Alexander, Baron von Eggers (1844-1903) (Fig. 26) and was believed to be extinct. It belongs to the family of the Capparaceae.

Henrik Franz Alexander von Eggers (1844-1903), a Dane born in Schleswig, began an important botanical exploration of the Antillean flora in 1870 on St. Croix, from where he made his first publication in 1876 , under the title of St.Croix's Flora. After moving to St. Thomas, he studied the local vegetation and explored the neighbouring islands of Water, Vieques, and St. Jan, which resulted in his publication in 1879 of The Flora of St. Croix and the Virgin Islands.

In 1893 Henrik Alexander von Eggers travelled to Ecuador and purchased a cocoa plantation named "Hacienda el Recreo" in the coastal province of Manabí, not far from the Bay of Caraquez. He spent the next six years in Ecuador and -aside from his agricultural enterprisespent his time botanizing in the coastal lowlands. A few excursions took him also to Balao, on the slopes of the Sierra de Cuenca, and to Guayaquil.

Among the orchid specimens collected by Eggers in Ecuador, we find Vanilla odorata C.Presl., Dichaea longa Schltr., Cryptarrhena kegelii Rchb.f., Gongora grossa Rchb.f., and many others. In addition, in 1921 Schlechter described three species that were new to science amongst Eggers' Ecuadorian collections: Pogonia lutea, Polystachya ecuadorensis (Fig. 27), and Pleurothallis henrici (Fig. 28).

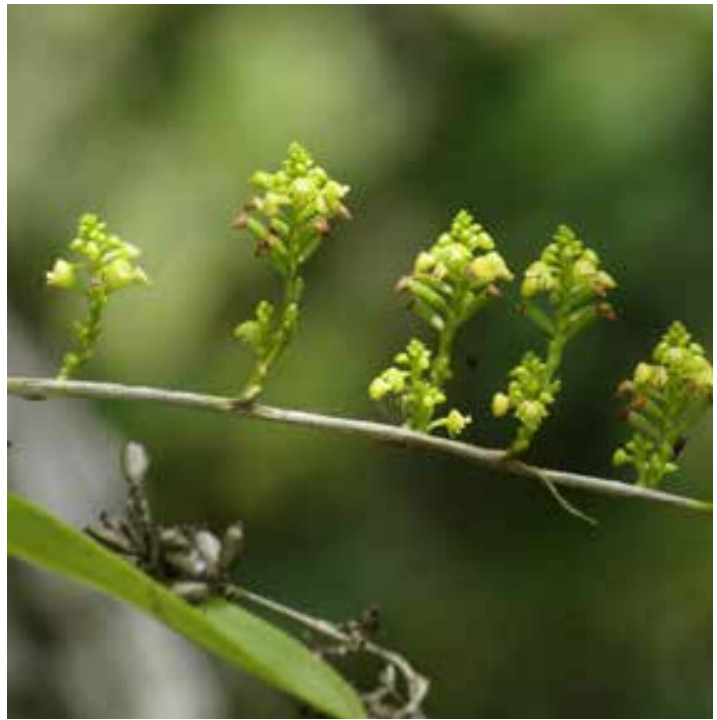

FIgURe 27. Polystachya ecuadorensis Schltr. [=Polystachya foliosa (Hook.) Rchb.f.]. 
The genus Eggersia, of the Nyctaginaceae was named for him by Joseph Dalton Hooker.

Louis (Aloysius) Mille (1873-1954; collected ca. 1894-ca.1940)

"The oldest collections at Herbarium QCA (Quito, Catholic University) are 890 specimens collected by Father Louis Mille, S. J. (1873-1954) (Fig. 29), who in 1894 studied botany under Father Luigi Sodiro, S. J., at the Jesuit college of San Gabriel in Quito" (Jórgensen et al. 1992: 53). The Jesuits established themselves in Ecuador in colonial times, and built a magnificent group of buildings surrounding the Church of the Society of Jesus (Fig. 30). The San Gabriel college is part of this architectural complex.

Louis Mille, a Jesuit of Belgian origin, arrived in Ecuador as a young man -probably around 1882- and soon became one of Luigi Sodiro's favorite students. Ecuador became his second home, and he would live in this country until the end of his days. In 1921 Rudolf Schlechter welcomed Mille onto Ecuador's botanical scene: "Father Louis Mille has continued in recent years with the study of the flora of Ecuador -and thus with the work of Jameson and Sodiro- with great zeal and botanical knowledge" (Schlechter 1921: 12). As the successor of Sodiro, who passed away in 1909, Mille developed his main botanical activity in Ecuador between 1900 and 1940 and published numerous articles and books on this subject, among them one of his main works: 'Nociones de Geografía Botánica aplicadas al Ecuador' (=Notions of geographic botany applied to Ecuador) published in 1922 (Dávalos 1977: 227).

Mille taught Botany at the prestigious Jesuit colleges in Quito and Riobamba, and his main collecting activities took place in the Andean regions surrounding these cities, especially, according to Schlechter, in the provinces Chimborazo and adjacent Tunguragua, on the slopes of the two famous volcanos that give the name to the provinces (Fig. 31). Other localities frequently visited by Mille were the provinces of Pichincha and Riobamba. In 1922, however, due to ill health, he moved to Guayaquil and continued his collections in Guayas and Manabí.

Dozens of new orchid species were described by Schlechter from the Andean collections of Louis Mille. Among them, we find Aa macra, Aa riobambae, Cranichis sororia, Cyclopogon macer, Cryptophoran-

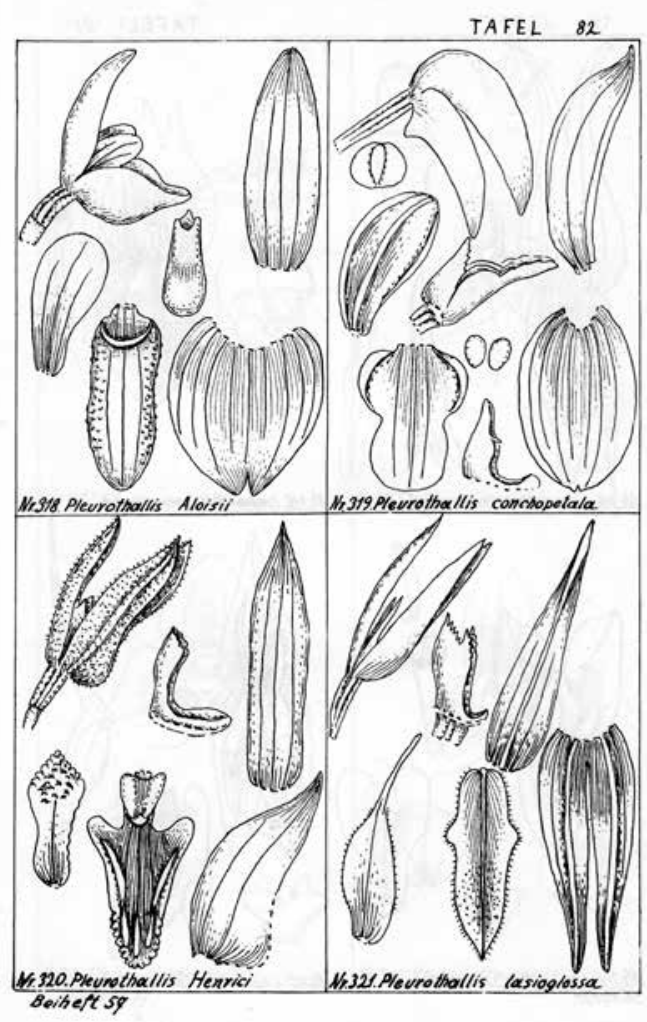

FIgure 28. Pleurothallis henrici Schltr. (lower left corner). Flower analysis by Rudolf Schlechter in Mansfeld, 1929: plate 82

thus beloglottis, Diothonaea viridiflora (Fig. 32), Epidendrum chortophyllum, Epidendrum cuniculatum, Epidendrum fruticetorum, Epidendrum geminatum, Epidendrum mojandae, Epidendrum orthocaule, Epidendrum riobambae, Epidendrum sarcoglottis, Lepanthes pensilis, Pleurothallis lassioglossa, Pleurothallis lloensis, Ponthieva disema, Ponthieva ecuadorensis, Ponthieva orchioides (Fig. 33-34), Stelis altigena, Stelis coturcoensis, and Stelis lloensis (Schlechter 1921).

Many other orchid species were named by Schlechter in honor of the great Belgian botanist. Worthy of mention are Cyclopogon millei, Epidendrum millei, Habenaria millei, Lepanthes millei, Liparis millei, Oncidium millei, Pleurothallis millei, Stelis millei, and Stenorrhynchos millei (Fig. 35) (Schlechter 2015).

It is noteworthy that among the many new orchids described by Schlechter from Mille's collections, we do not find a single one from the Ecuadorian low- 


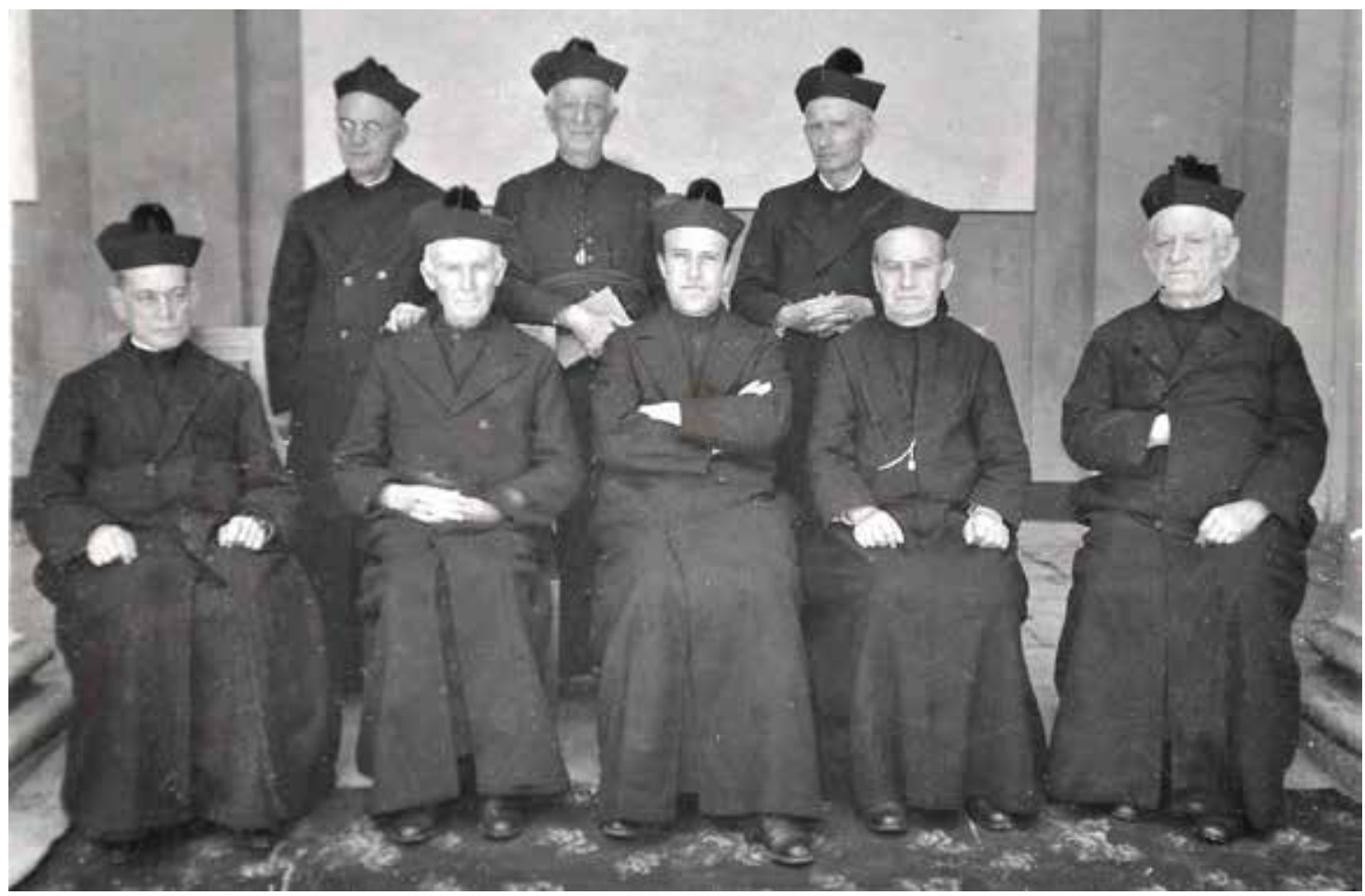

FIGURE 29. Father Louis Mille (1873-1954) (first from left, back row) with members of his congregation, 1940. Archives of Rudolf Jenny.

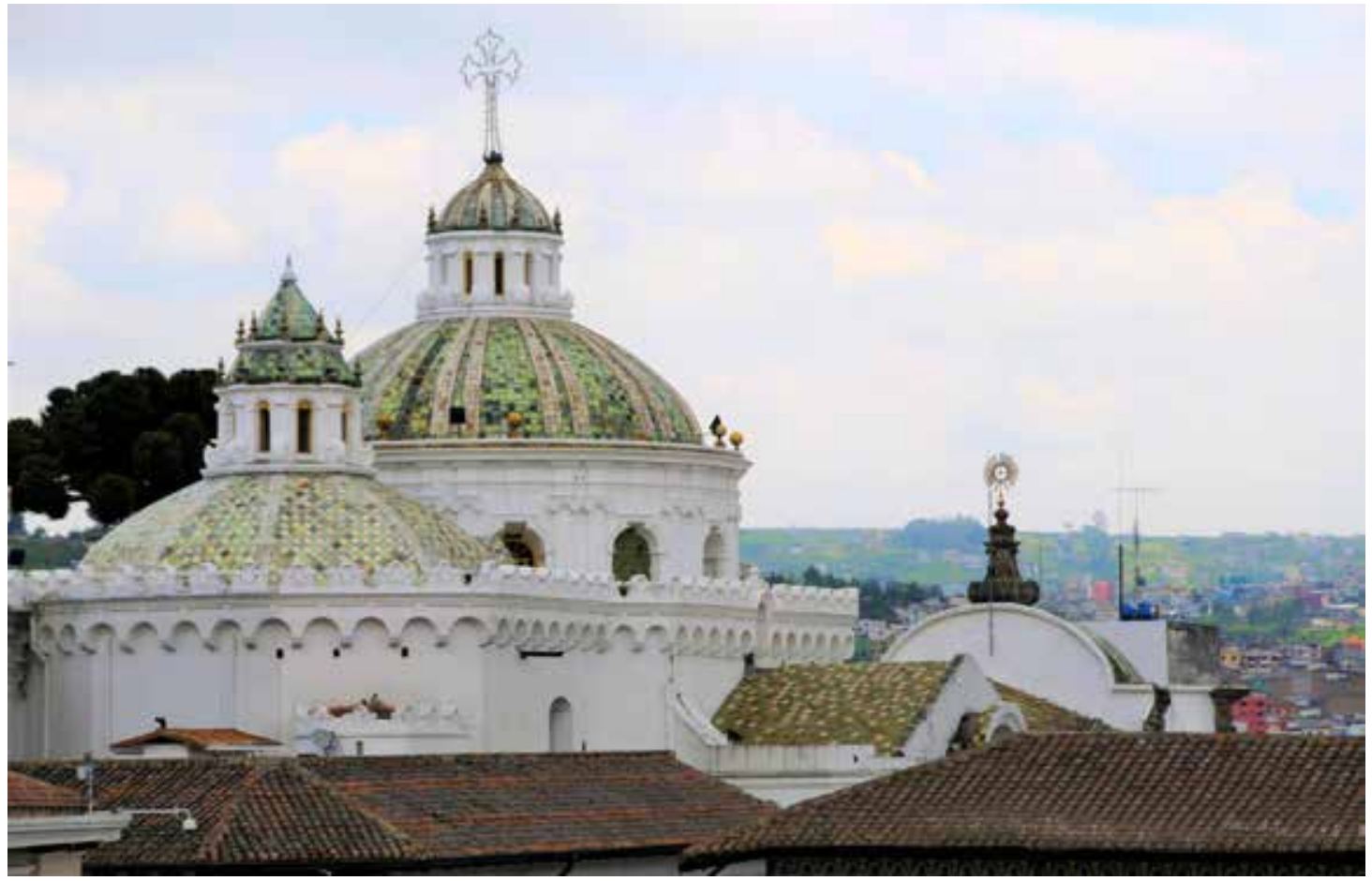

FIGURE 30. Domes of the church of the Jesuit Company in Quito. Photograph by Marcelo Quinteros.

LANKESTERIANA 21(2). 2021. (C) Universidad de Costa Rica, 2021. 


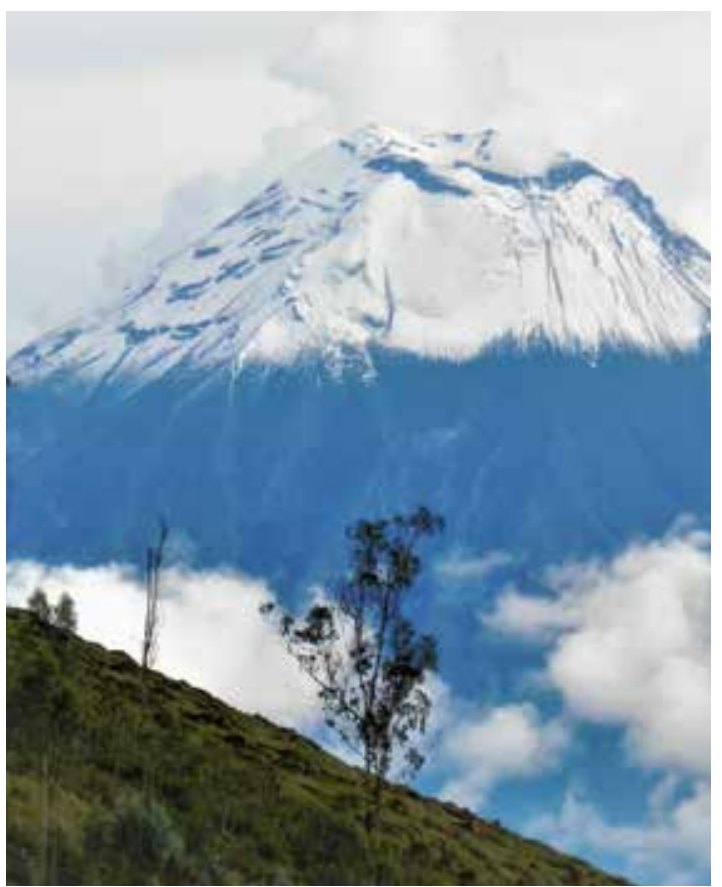

FIGURE 31. Tunguragua vulcano, the 'Black Giant'. Photograph by Andrés Heredia.

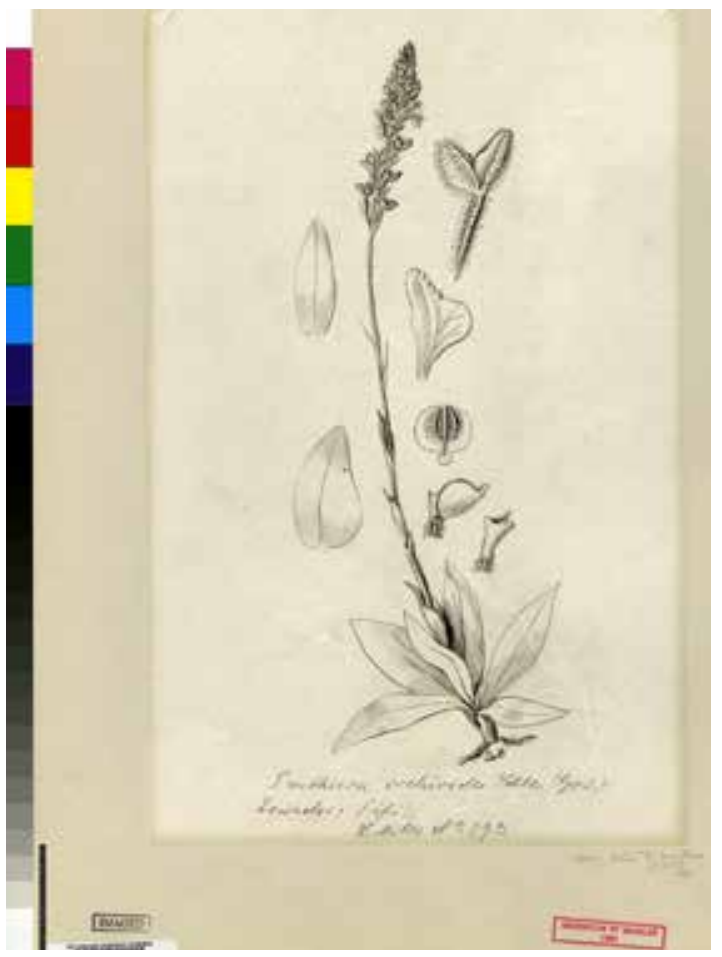

Figure 33. Ponthieva orchioides Schltr. Drawing of type, courtesy of Harvard University Herbaria, \#00103552.

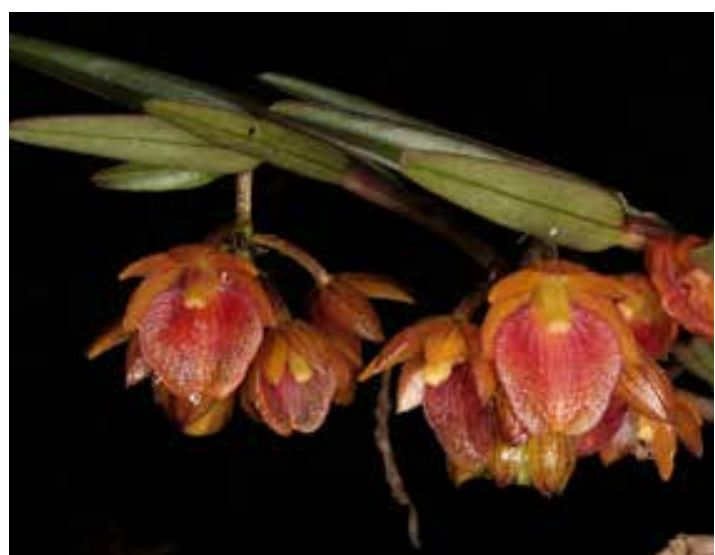

FIGURE 32. Diothonaea viridiflora Schltr. as Epidendrum neoviridiflorum Hágsater. Photograph by Laurens Grobler.

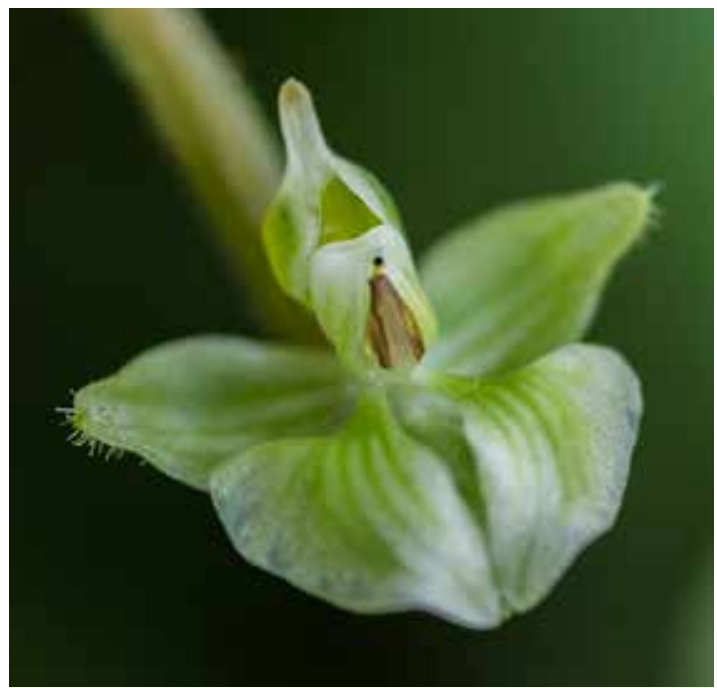

FIgure 34. Ponthieva orchioides Schltr. Photograph by Jim Fowler.

lands, where Mille collected for several years. The reason for this seems clear if we remember that Mille only started collecting along the coast at a time when Schlechter was nearing the end of his life's work.

August RimbaCh (1862-1943; collected 1894-1934)

August Rimbach received his Ph.D. in Natural Sciences in 1897 after studying under Swiss Professor Simon Schwendener at the University of Berlin. In 1890 he was offered the position of Professor of Botany and Zoology at the University of Cuenca, Ecuador, where he spent the following four years. 


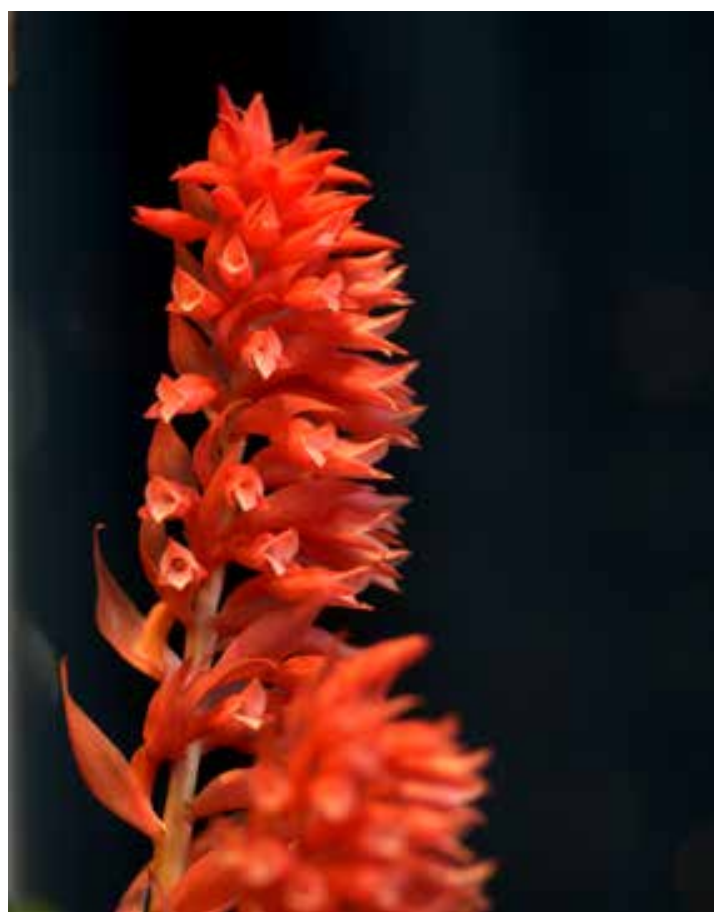

FIGURE 35. Stenorrhynchos millei Schltr. as Stenorrhynchos speciosum (Klotzsch) Rchb.f. Unknown photographer.

In 1894, together with his brother Carl, Rimbach descended the Río Bobonasa to the Río Pastaza of eastern Ecuador. The journey was described in an article published in 1897 by the German Geographic Society under the title Reise im Gebiet des oberen Amazonas (=Journey to the region of the Upper Amazon), together with a detailed map of the complex river systems in eastern Ecuador (Rimbach 1897, plate 23; Renner 1993: 4) (Fig. 36).

Between 1895 and 1900, August Rimbach travelled to Germany and was for a short period at the University of Nebraska in the United States. He then returned to Ecuador, where he settled in Guayaquil until 1908 when he decided to move once more to the city of Riobamba, the capital of the province of Chimborazo, at an altitude of 2750 m. (Fig. 37). In 1910 Rimbach was called to serve as professor of Botany at the Agronomical Institute in Montevideo, Uruguay, with his brother Carl as his assistant. For almost ten years, he would make important studies and wrote a series of articles in which he tried to further Uruguay's agricultural production (Izaguirre 2006: 2). In 1921 the Rimbach brothers were back in Riobamba, where they would live for the rest of their lives (Acosta Solís 1968: 45-46 and Arosemena

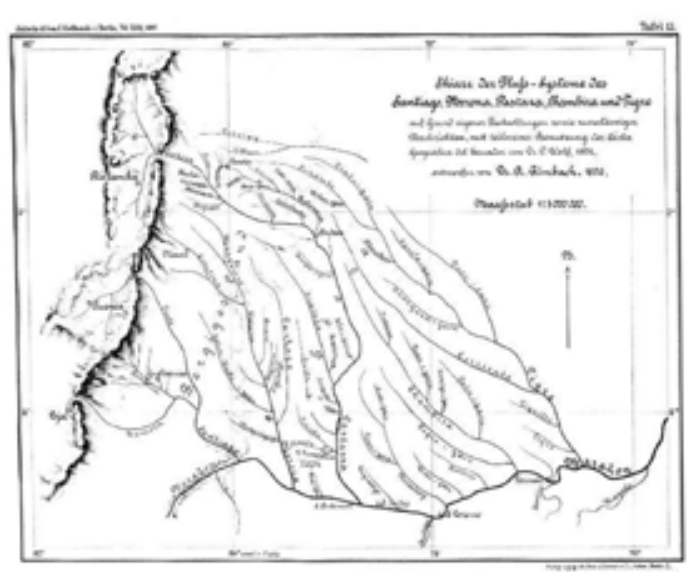

Figure 36. Map drawn by Rimbach of the river systems in Ecuador's Amazonia. In Rimbach, 1897, plate 12.

2017: 13). Rimbach's collections from that area are famous for their quality. His collections were widely distributed; the first set apparently went to Berlin, where it was destroyed during the Second World War; other sets are today in Munich, Stockholm (Fig. 38), Geneva, Jena, Chicago, Cambridge, and Washington (Jørgensen \& León-Yañez 1999: 36).

In his orchid flora of Ecuador, Schlechter described an important number of new orchid species collected by Rimbach, in the vicinity of Guayaquil and in the Andean valleys around Riobamba. Worth mentioning among those collected in the province of Guayas are Bulbophyllum ecuadorense (Fig. 39), Campylocentrum ecuadorense, Campylocentrum rimbachii (Fig. 40), Epidendrum rimbachii (Fig. 41), Maxillaria hedyosma, and Notylia rimbachii. In the province of Chimborazo Rimbach collected Cyclopogon rimbachii.

Peru. The geography of Peru is similar in many ways to that of Ecuador. In the east, we have the lowlands of the Amazon basin, called selva baja, representing over half of the country's territory. The region is one of the immense forests irrigated by one of the world's largest river systems, including the Amazon itself and its tributaries Huallaga (Fig. 42), Marañon, and Ucayali Rivers.

The main city in the region is Iquitos, which grew in the 1880 s from a small village to a large city, following the rubber boom, the plantations of which extended from Brazil to Peru. The rubber boom lasted until 1914 when Iquitos fell back into the misery of a small village on the shores of the Amazon (Fig. 43). 


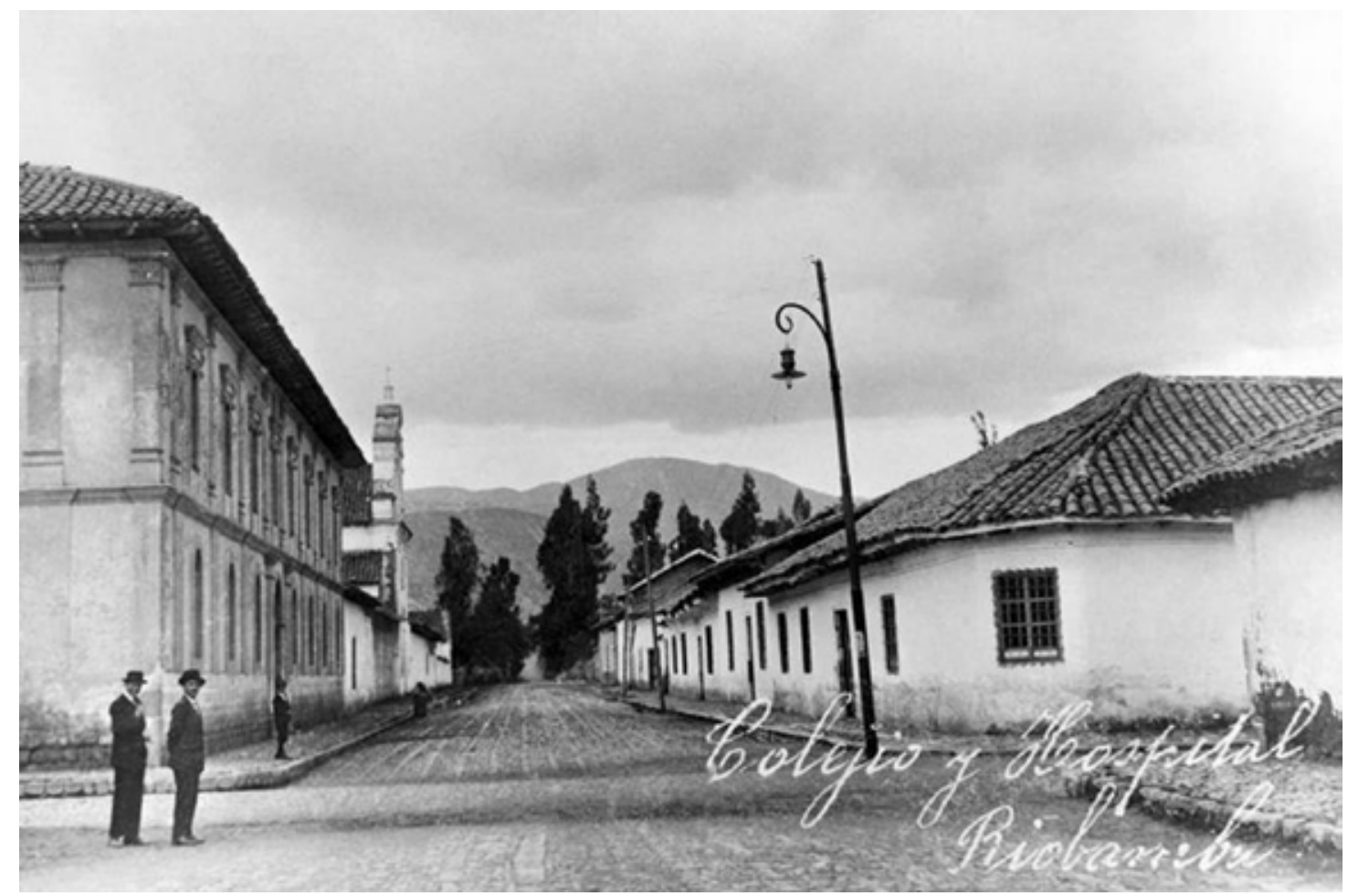

FIGURE 37. Riobamba, ca 1900. Unknown photographer.

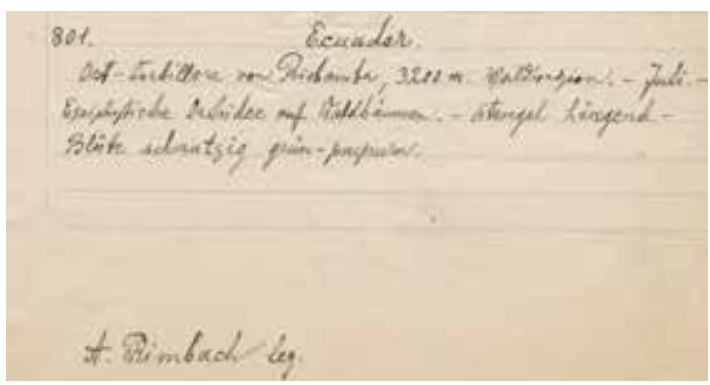

FIGURE 38. Rimbach signature and herbarium label of type specimen of Pleuranthium cardiochilum Garay. Courtesy of Swedish Museum of Natural History Department of Botany, S-R-4946.

With elevations up to $6600 \mathrm{~m}$, the Andes occupy the centre of the country and offer the most extensive variety of climates in Peru. Conditions vary from semiarid in the valleys to moist at higher elevations and towards the western flanks. Two regions show special characteristics. The first is the $4000 \mathrm{~m}$ table land "altiplano", which extends in Peru from Puno on the shores of Lake Titicaca across portions of Bolivia, Chile, and Argentina. (Fig. 44). The other is the mountainous al- pine tundra ecosystems of lower elevation regions of northern Peru (Fig. 45).

The Peruvian coast can be divided into two prominent sub-regions with entirely different climates: the central and southern Pacific coast have a subtropical desert climate, with almost no rainfall or vegetation. On the other hand, the northern coast is a typical tropical savanna, with clearly marked dry and rainy seasons. The vegetation consists of shrubs, equatorial dry forests (Fig. 46), and mangroves. Two main rivers, the Chira and the Tumbes, irrigate this region.

The history of orchidology in Peru begins with the use that noble Incas gave to a plant with which they adorned the heads of young maidens. This they called Viñay Huayna or Wiñay Huayana, which translates into forever young or eternal youth. This plant was nothing other than Epidendrum secundum Jacq. In 1942 a smaller Inca city was discovered near Machu Picchu. The eminent Peruvian archaeologist, Dr. Julio C. Tello, gave it the name of Wiñay Wayna. It is no coincidence that Epidendrum secundum grows profusely in the surroundings of Wiñay Wayna (Ossenbach 2020: 31). 


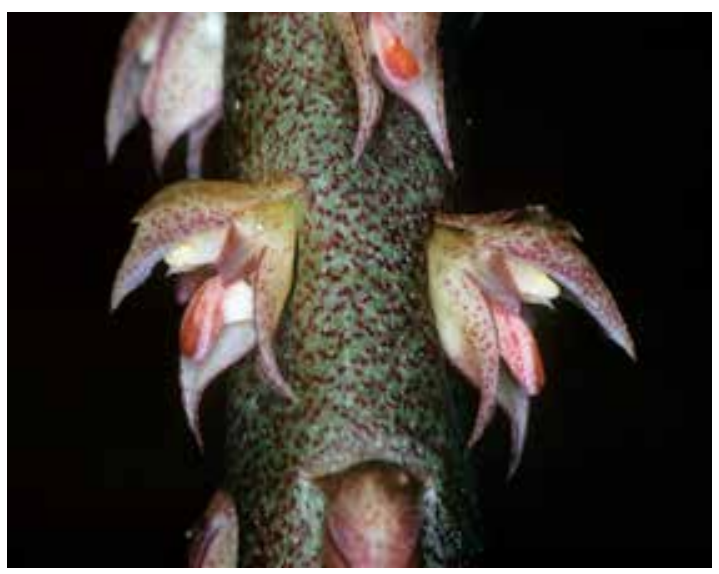

FIGURE 39. Bulbophyllum ecuadorense Schltr. as B. pachyrachis (A.Rich.) Griseb. Unknown photographer

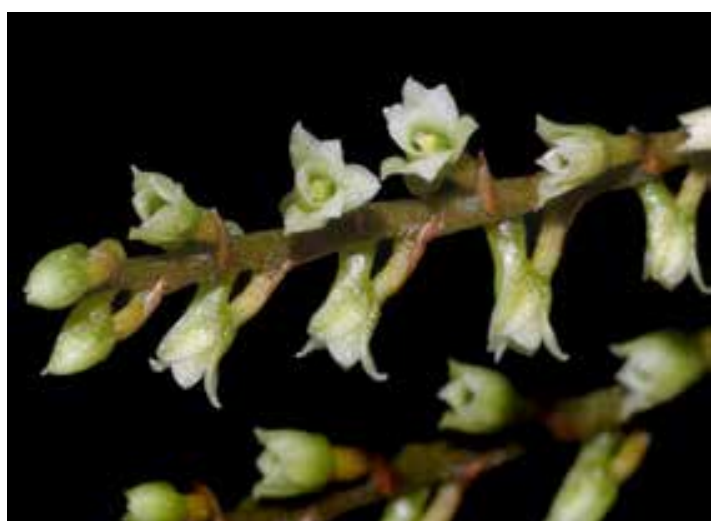

FIgure 40. Campylocentrum rimbachii Schltr. as Campylocentrum pachyrrhizum (Rchb.f.) Rolfe. Photograph by Von Gastam

The first herbarium specimens of Orchidaceae from Peru are at the Natural History Museum in Paris. They were collected by Joseph de Jussieu (1704-1779) during his odyssey in that country between 1735 and 1771 (Ossenbach 2020: 90) (Fig. 47).

The first state-funded Spanish botanical expedition arrived in Peru in 1777 under the direction of Hipólito Ruiz (1653-1816 and José Pavón (1754-1844). They were accompanied by French botanist Joseph Dombey (1742-1794). Their mission was to explore and make botanical collections in Peru and Chile and at a later stage in Guayaquil, on Ecuador's Pacific coast. Thousands of specimens and a significant number of beautiful botanical illustrations were sent to the 'Botanical Office' in Madrid. Pavón sold a majority of the specimens and

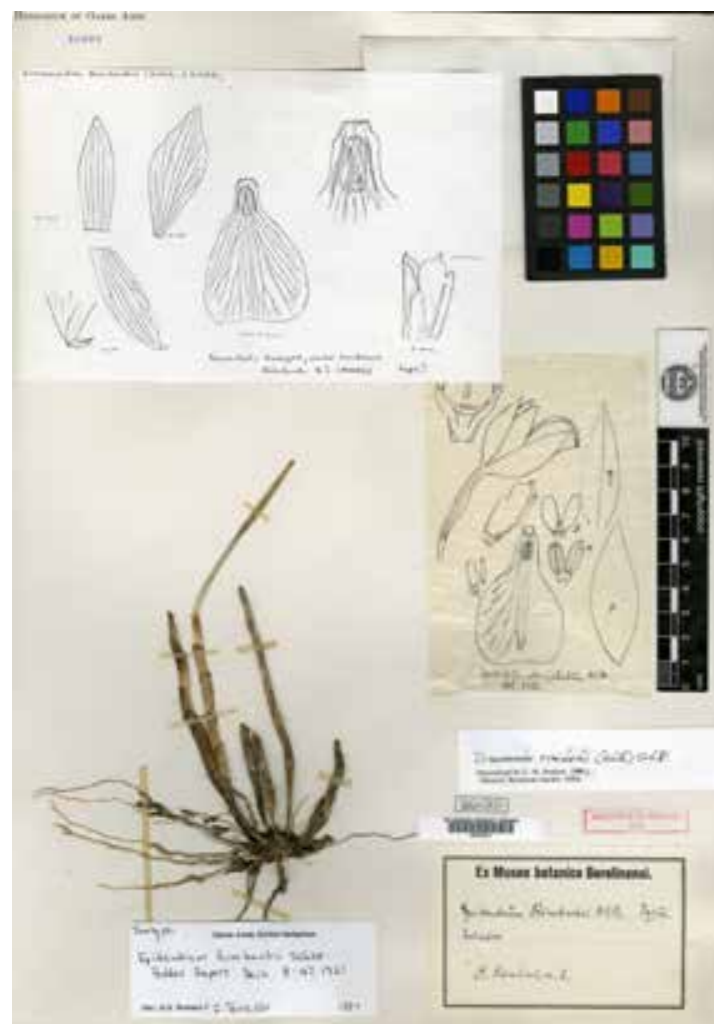

FIgURE 41. Isotype of Epidendrum rimbachii Schltr. Herbarium of Oakes Ames \#40084.

illustrations to European collectors. However, the portion that was retained in Madrid was not described for almost 150 years. Many new orchid genera and species were determined by Ruiz and Pavón, although only a Prodromus and the three first volumes were published of their intended Flora Peruvianae et Chilensis (Fig. 48-49) (Ruiz \& Pavón 1798-1802).

Notwithstanding all the above, the orchid collections of Ruiz, Pavón, and Dombey were outstanding and the botanical material now deposited at the Royal Botanical Garden in Madrid and the Natural History Museum in Paris are of enormous importance.

A singular event was the arrival, in May 1790, of the expedition of Alessandro Malaspina. On the expedition was the Czech botanist Thaddeus Haenke (1761-1817). Haenke spent several months in Peru, with Ruiz and Pavón acquiring many important botanical specimens. Haenke would stay in South America for the rest of his life and never return to Europe again. His botanical collections in Peru and Bolivia, which included many 


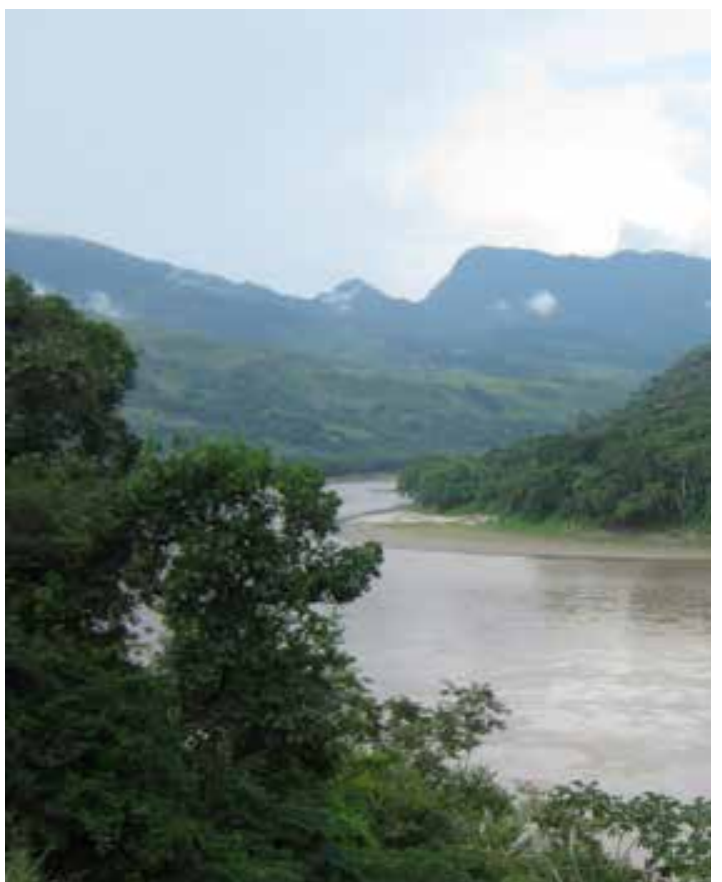

FIGURE 42. Huallaga River. Unknown photographer.

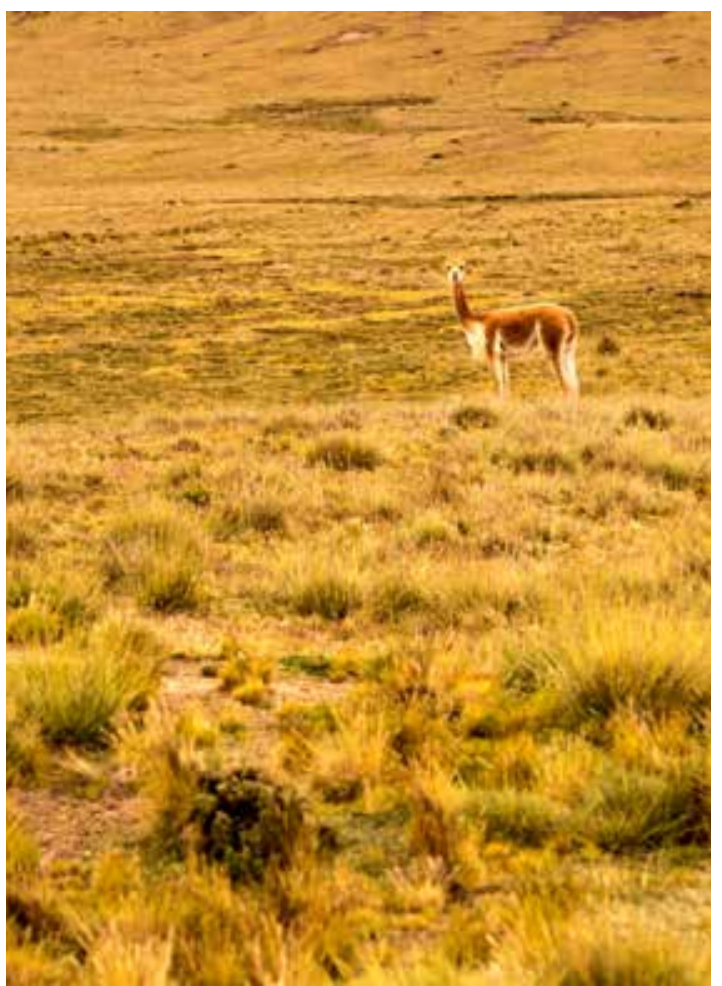

FIGURE 44. The Puna ecoregion. Unknown photographer.

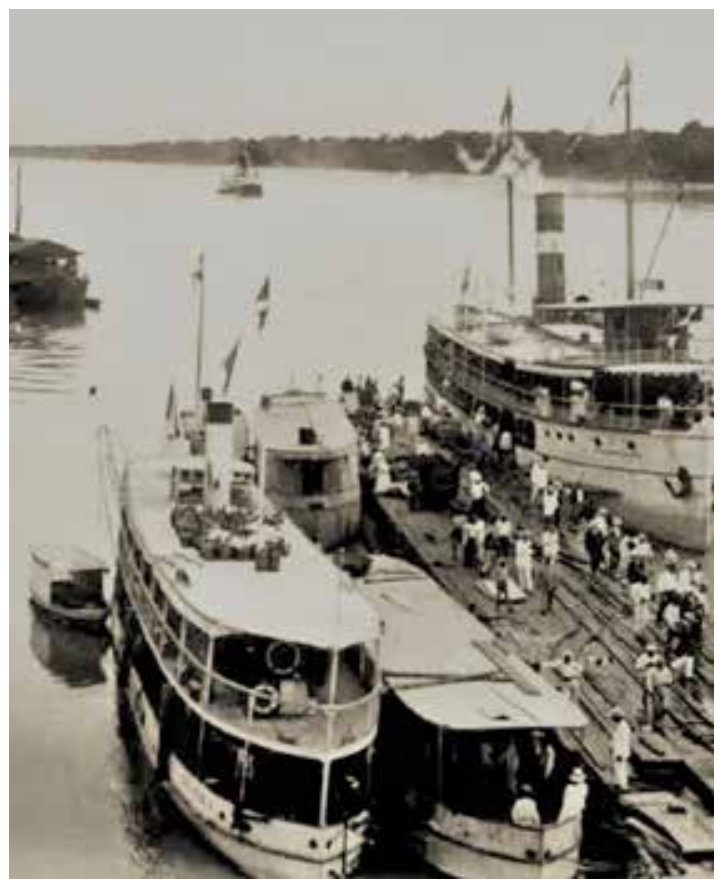

FIgURE 43. Boat landing in Iquitos, ca. 1900. Unknown photographer.

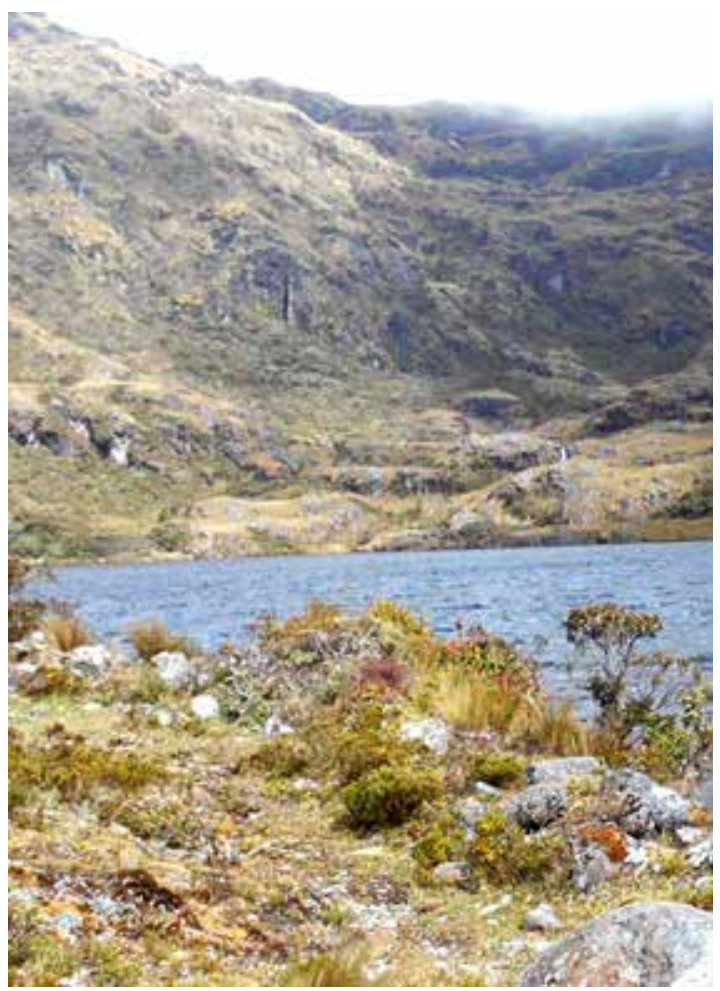

FIgURE 45. The páramo of Piura. Unknown photographer.

LANKESTERIANA 21(2). 2021. (C) Universidad de Costa Rica, 2021. 


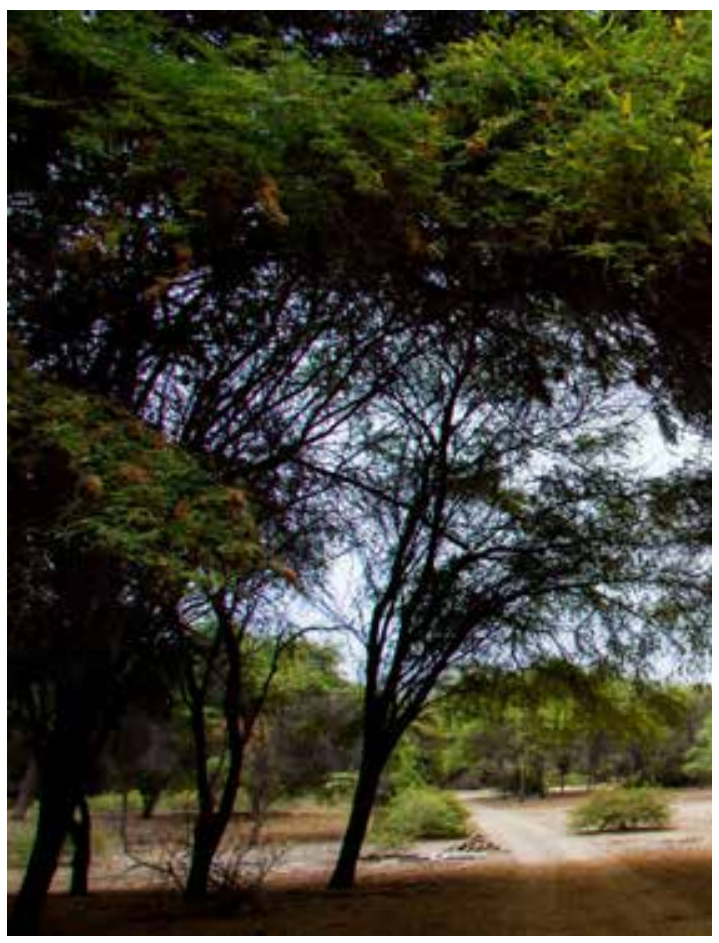

FIGURE 46. Tropical dry forest near Tumbes. Unknown photographer.

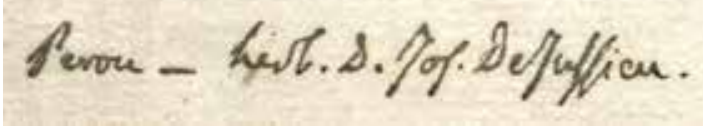

FIGURE 47. Jussieu herbarium label on an undetermined specimen of Epidendrum collected in Peru. Courtesy of MNHN Paris, \#MNHN-P-P00673094.

new orchid species, were later described by his Czech countryman Karel Bořivoj Presl in his work Reliquiae Haenkeanae. We remember Haenke in Epidendrum haenkeanum Presl, Gyrostachys haenkeana Kuntze, and Maxillaria haenkei Correll.

Eduard Friedrich Poeppig (1798-1868) went from Chile to Peru in 1829 and followed in the footsteps of Ruiz and Pavón over months, collecting in Huanuco and Cuchero in the Peruvian Andes before descending the Huallaga River to the Amazonas and then crossing into Brazil. Many new orchid genera and species were described from his herbarium specimens. Poeppig, with the collaboration of Austrian botanist Stephan Endlicher (1804-1849), published the botanical results of his travels

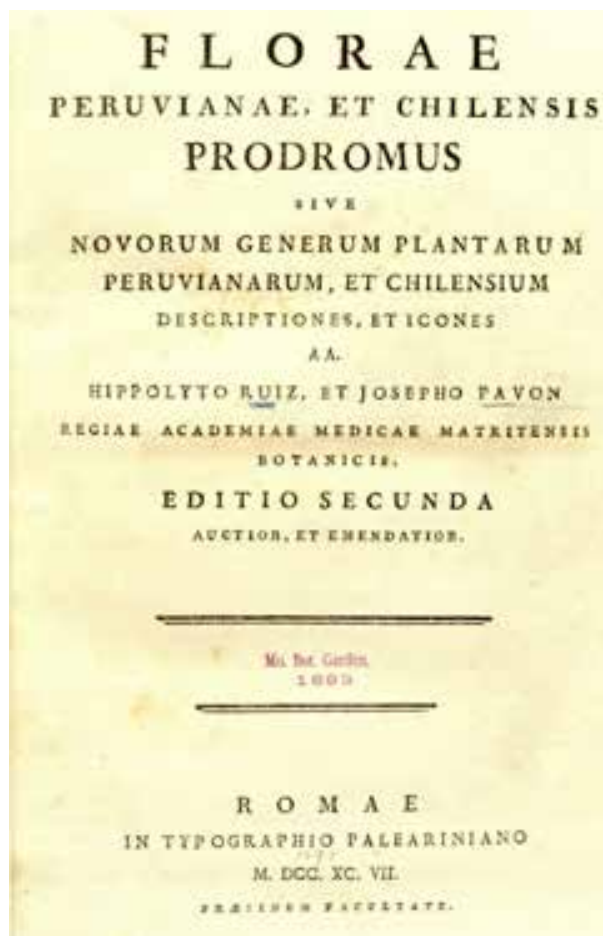

Figure 48. Title page of the Prodomus for the Flora Peruviana et Chilensis (2nd edition, 1797).

between 1835 and 1845 in a large, beautifully illustrated work entitled Nova genera ac species plantarum quas in regno chilensi, peruviano et in terra amazonica (Fig. 50).

The British traveller Andrew Mathews (1801-1841) spent the last ten years of his life in Peru. John Lindley described many new orchids from his botanical collections. Schlechter's only complaint was the fact that Matthews never indicated the precise collecting locations.

Antonio Raimondi (1826-1890) was an Italian-born Peruvian scientist who arrived at the port of Callao in 1850 and remained in the country until his death. According to Schlechter and Weberbauer, Raimondi gathered over 20,000 herbarium specimens, among which Schlechter assumed must have been many orchids. However, Raimondi's collection remained undescribed until long after Schlechter's death. The Field Museum of Natural History in Chicago holds a specimen of a new orchid species described by Raimondi, Chloraea undulata $(=C$. pavonii Lindl.) (Fig. 51-52), also known as 'the orchid of Lima'.

Finally, in 1859 Richard William Pearce (ca. 18351868) was sent by the firm of Veitch \& Sons as a 'collector of plants, seeds, land-shells and other objects of 


\section{IIYPOIITI RUIZ FLORA PERUANA} in QUA

continentur rariorcs $\mathrm{A} \cdot \mathrm{bo}$ res, et Plantac fecundum Liñeanum Syftema determinatae, et deferiptae: obferatis locis natelibus, tempore florgantiac, phori

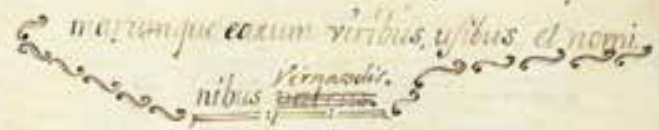
Tons pximexe

thin a $\{778,1779,175=, 1781,1792$ $178 Z_{n}$

Figure 49. Front cover of the manuscript of the first volume of the Flora Peruviana et Chilensis.

Natural History'. He travelled initially to Chile before spending three years in Peru, Bolivia, and Ecuador. From Peru, we know of his collections of Odontoglossum brachypterum Rchb.f., Otoglossum brevifolium (Lindl.) Garay \& Dunst., Odontoglossum multistellare Rchb.f., and Pseudocentrum bursarium Rchb.f. The genus Pearceae of the Geseneriaceae was named in his honour.

\section{WiLLIBaLd LeChLER (1814-1856; collected 1850-1854)}

The son of a clergyman, Willibald Lechler (Fig. 53) was born in the German city of Klosterreichenbach. He studied pharmacy in Reutlingen and practiced his profession in Augsburg, Vevey, Geneva, and Basel. Lechler established himself in Stuttgart where he owned a pharmacy from 1839 to 1849 (Krauss 1858). In 1850 Lechler was called upon to take part in an expedition to Chile with an advisory committee of the Stuttgart Society for Emigration and Colonisation to inspect land for a possible settlement along the River

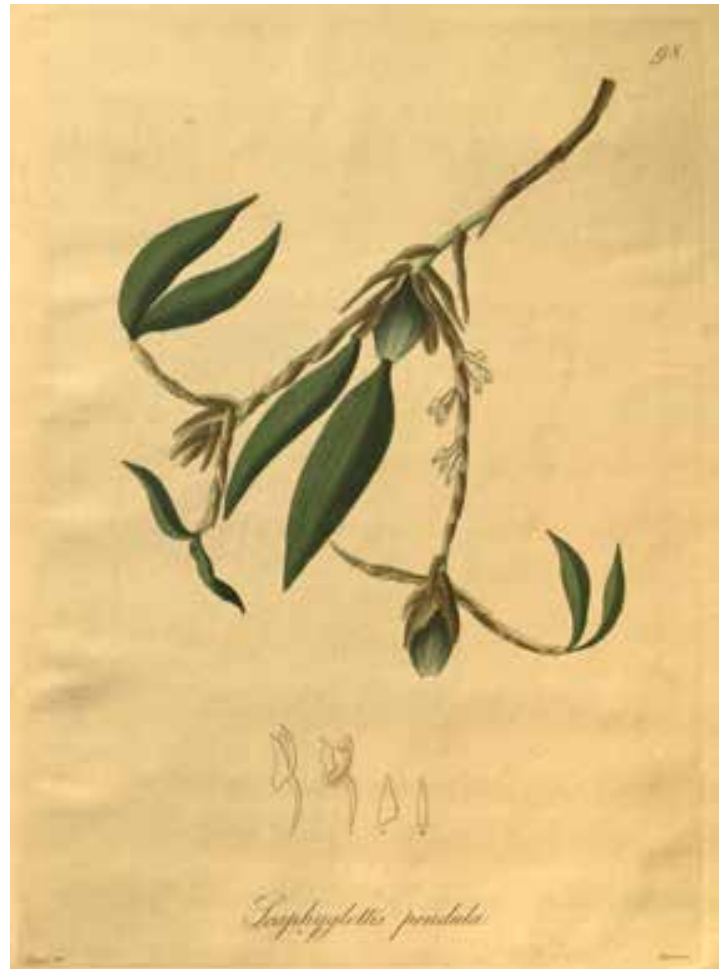

FIgURe 50. Scaphyglottis pendula Poepp. \& Endl. [= Ornithidium pendulum (Poepp. \& Endl.) Cogn.], collected near the village of Cuchero. Plate 98 of Nova Genera ac Species..., volume 1 .

Bueno. When the expedition returned to Germany, Lechler stayed in Chile and settled at Arique. From there, he made exploratory journeys and collected plant specimens for sale in Europe. In 1850 he collected in the Falkland Islands, in Chile from 1850 to 1852 and 1852-1853 along the Straits of Magellan.

In 1854 Lechler went to Peru, where he collected mainly in Puno (Fig. 54). He stayed until 1855 when he returned to Germany. After his first wife died in 1854 in a boat accident on the river Calle-Calle in Chile, Lechler married again and in 1856, returned to South America. After crossing the Isthmus of Panama, he sailed to Guayaquil but died at sea, a victim of yellow fever.

Willibald Lechler's plants from the Falkland Islands, Chile, and Peru were distributed in Europe by Swiss botanist Rudolph Friedrich Hohenacker (1798 -1874). They were advertised as 'W. Lechler plantae insularum Maclovianarum', 'W. Lechler plantae chilenses', and 'W. Lechler plantae peruvianae' (Godley 1970: 69-70). 


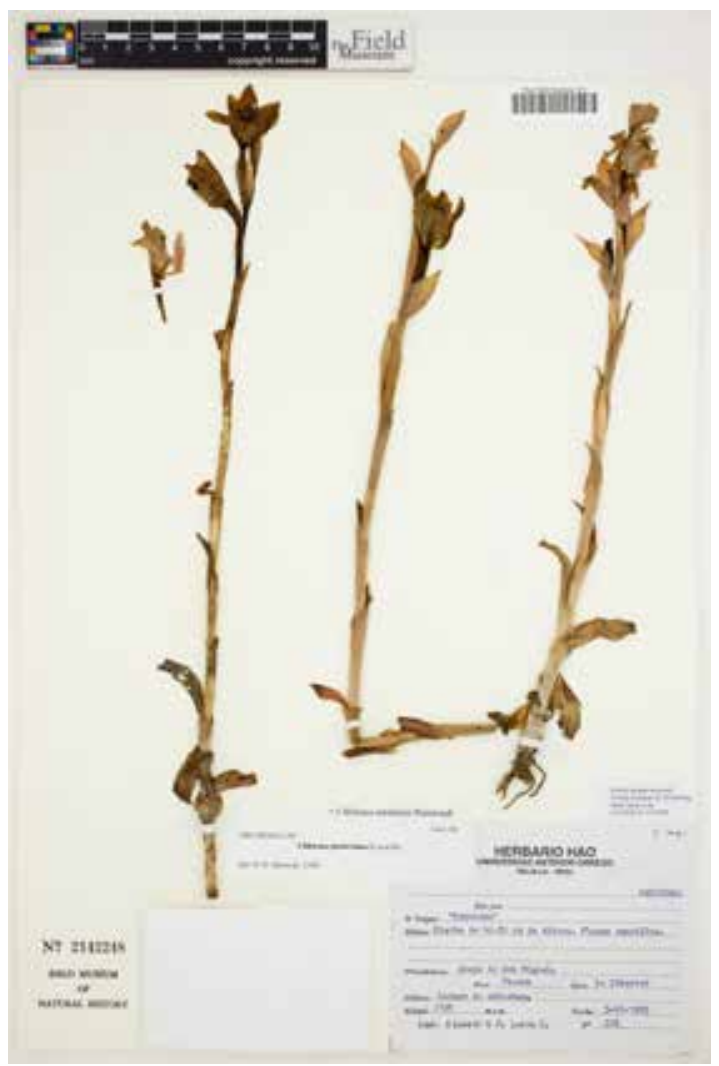

FiguRe 51. Chloraea undulata Raimondi. Courtesy of Field Museum of Natural History \#2142248.

Several new orchid species were found among Lecher's botanical collections. Lindley described Chloraea lechleri (Fig. 55), Reichenbach Epidendrum lechleri, Schlechter Aa lechleri and Brachystele lechleri (Fig. 56), and Ormerod Microchilus lechleri. Schlechter also transferred Reichenbach's Altensteinia inaequalis, whose type specimen had been collected by Lechler (Fig. 57), to $A a$ inaequalis (Rchb.f.) Schltr.

Serafín Filomeno (1846-1922; collected ca. 19001910) (In collaboration with Delsy Trujillo)

"The small collections which I received from Mr. Serafín Filomeno (1846-1922) from the vicinity of Moyobamba have shown that this is the homeland for the beautiful Cattleya O'Brien, and magnificent species of Coryanthes, Stanhopea, Epidendrum, Maxillaria, Odontoglossum, Brassia, and many other types" (Schlechter 1921b: 28).

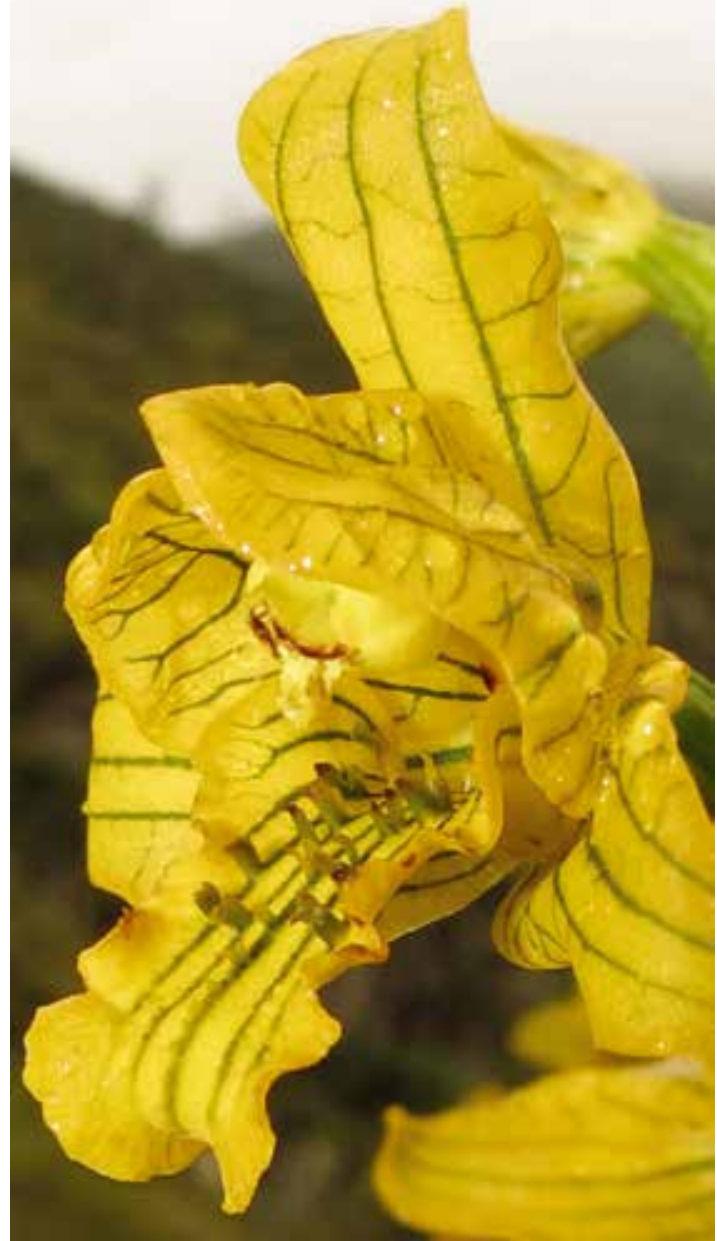

FiguRe 52. Chloraea undulata Raimondi (=Chloraea pavonii Lindl.), 'the orchid of Lima'. Photograph by Delsy Trujillo.

Filomeno was born in San Jerónimo de Ica, in southern Peru, and at the age of 10, moved to Lima, where he completed his primary and secondary studies. In 1876 he received his Ph.D. in Humanities, Philosophy, and History at the University of San Marcos. After that, he decided to dedicate his life to education and was the director of several high schools in El Callao and Lima. In 1889 he was put in charge of the foundation of a new high school in Moyobamba, the "Colegio Secundario San José' (Fig. 58) (Alves Milho 2019).

Moyobamba is located in northern Peru, valley of Alto Mayo, at an elevation of $900 \mathrm{~m}$ on the eastern slopes 


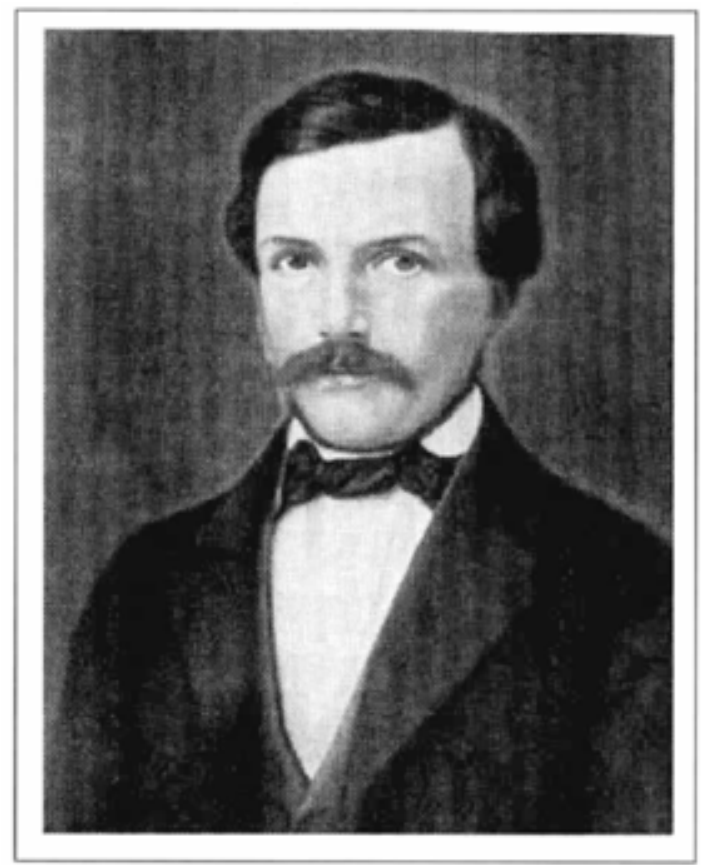

FIGURE 53. Willibald Lechler (1814-1856). Archives of Rudolf Jenny.

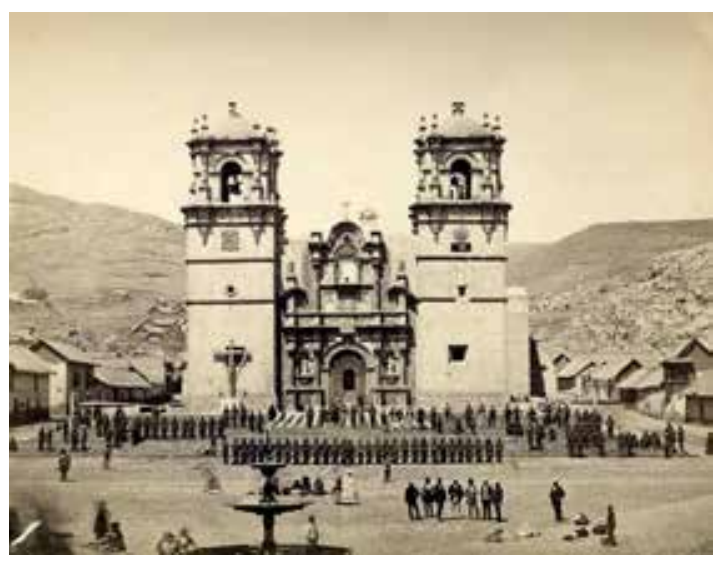

Figure 54. Cathedral of Puno, 1875. Allegedly the oldest photograph of Puno, by Ricardo Villalba.

of the Andes. It was the first city founded by Spaniards in the Peruvian jungle. About 3500 different orchid species grow in the neighbourhood of the city, and for this reason, it is known in Peru as "the city of orchids". Rudolf Schlechter dedicated several new orchid species found amongst Filomeno's collections to this city: Cyclopogon moyobambae (Fig. 59), Schomburgkia moyobambae, and Notylia moyobambae.

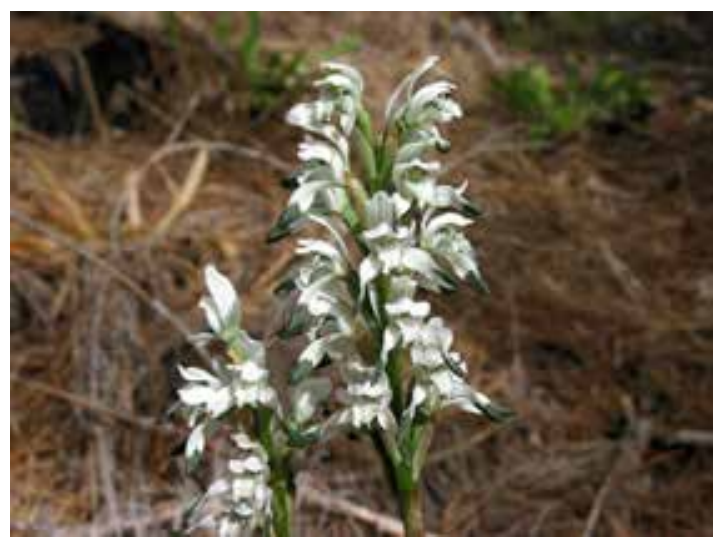

FIgURE 55. Chloraea lechleri Lindl. Archives of Rudolf Jenny.

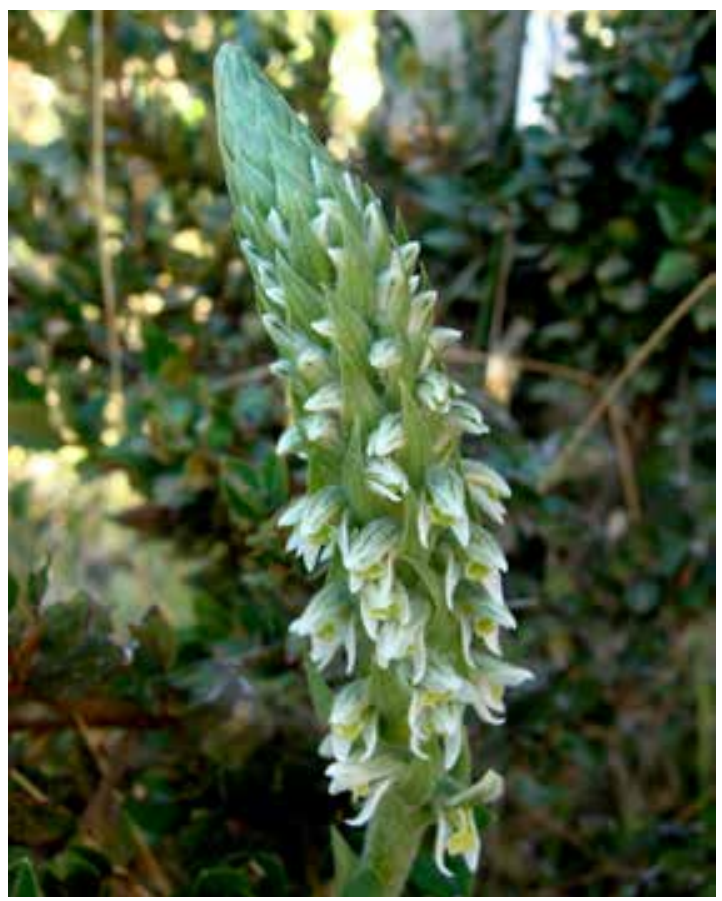

FIGURE 56. Brachystele lechleri Schltr. as Brachystele unilateralis (Poir.) Schltr. Photograph by Patricio Novoa.

Filomeno left Moyomaba in 1909 and moved to Iquitos, the capital of the Department of Loreto, on the banks of the Amazon. There he would live, alternating between work at public schools and a small private school he had founded until he passed away in 1922 (Herrera 1937).

During his time in Iquitos, Serafín Filomeno explored the Department of Loreto and continued sending new orchids to Schlechter, who dedicated several new 


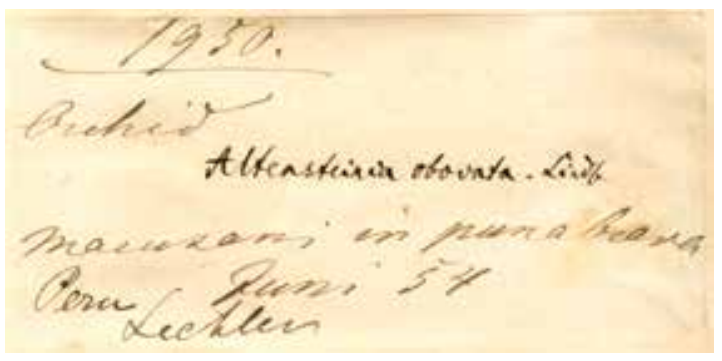

FIGURE 57. Herbarium label of Altensteinia inaequalis Rchb.f. Kew Herbarium \#K000364533.

species to this territory Scaphyglottis loretoenses (Fig. 60), Trigonidium loretoense, and Campylocentrum loretoense. Several new orchid species were dedicated by Schlechter to Filomeno himself, among them Brassia filomenoi, Epidendrum filomenoi (Fig. 61), Xylobium filomenoi (Fig. 62), Lycaste filomenoi (Fig. 63), and Stelis filomenoi. Schlechter mentioned an additional new species as growing in the Department of Loreto: a white and yellow Sobralia filomenoi. However, no species of Sobralia has ever been described under that name.

\section{Eugen Koehler (father) (1866-1945), Anton and Carl Koehler (sons) (-); collected 1906-1919) (In collaboration with Delsy Trujillo)}

Schlechter seldom provided many biographical details about those who contributed to his herbarium. This is -once more- the case with Eugen Koehler, a German seaman born in Munich who arrived in 1894 in Peru, where he dedicated himself to the cultivation of coffee in the valley of Chanchamayo, also called the 'gateway to the Amazon' (Fig. 64)

Koehler's coffee plantation, the 'Hacienda La Merced', and the valley of Chanchamayo as a whole became over the years well known for the incredible richness of their orchid flora. Schlechter would dedicate Pleurothallis chanchamayoensis (Fig. 65) to this region.

Eugen Koehler made a small collection of orchids in 1906, which was described by Rudolf Schlechter in 1912 in his Orchidaceae novae et criticae, Decas $X I X-X X$ (Schlechter 1912). In 1921 Schlechter again published specimens of the Koehlers, now collected jointly by the father and his sons, Anton (Antonio) and Carl (Carlos), in his Die Orchideenfloren der südamerikanischen Kordillerenstaaten, vol IV, dedicated to Peru (Schlechter 1921). Unfortunately, like so many others,

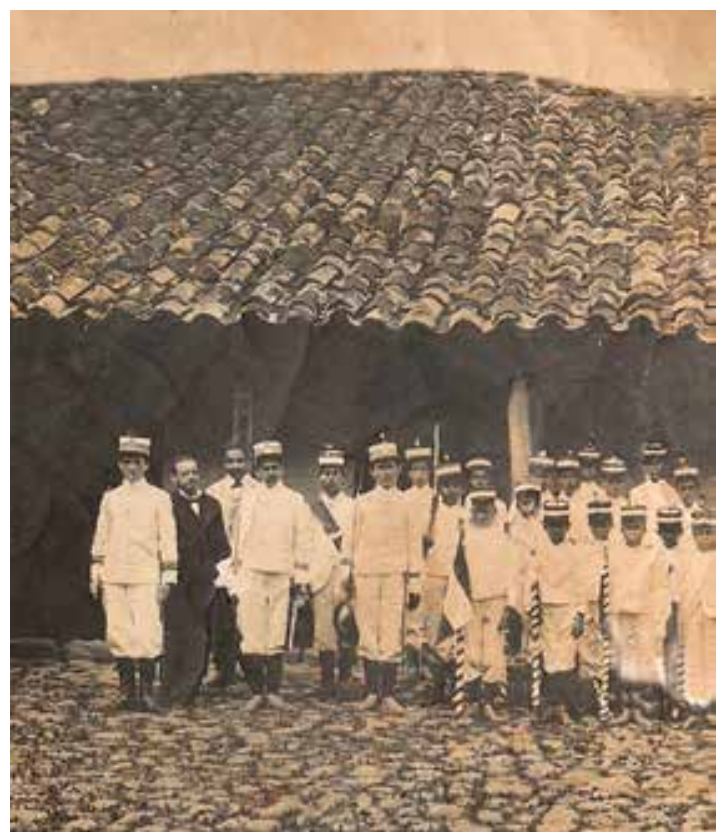

FIGURE 58. Serafín Filomeno (1846-1824) (in dark suit), together with his students at the Colegio de San José in Moyobamba, ca. 1905. Notice the students in gala uniform but barefoot! Unknown photographer.

all these specimens were destroyed during the bombing of Berlin during World War II.

Antonio and Carlos Koehler continued botanizing, and after Schlechter's death, sent a number of orchid specimens in 1930 to the Missouri Botanical Garden in St. Louis, Missouri (Herrera 1937b).

Eugen Koehler collected several new orchid species, among them Cyclopogon densiflorus, Gomphichis plantagineae, Pachyphyllum tenue, Physurus stenocentrum, Pleurothallis divaricans, Ponthieva microglossa (Fig. 66), and Stelis rhomboglossa.

Many others were dedicated to him, among them the new orchid genus Neokoehleria (= Comparettia), with two species: Neokoehleria equitans (type) (Fig. 67) and Neokoehleria peruviana (Fig. 68). Other orchids that carry Koehler's name are Cranichis koehleri (Fig. 69), Gomphichis koehleri, Elleanthus koehleri, Lepanthes koehleri (Fig. 70), Notylia koehleri, and Odontoglossum koehleri and Stelis koehleri (Fig. 71).

Koehler's sons collected the already mentioned Pleurothallis chanchamayoensis and Odontoglossum trilobum. In addition, several other orchid species from amongst their collections were dedicated by Schlechter to 


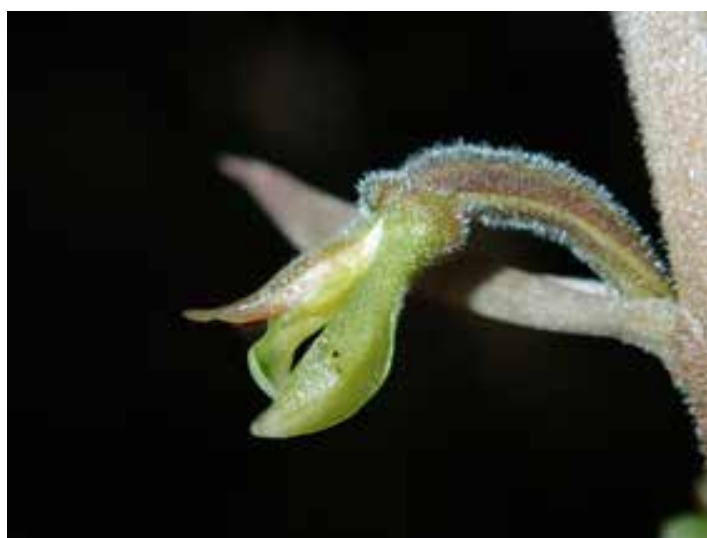

FIgure 59. Cyclopogon moyobambae Schltr. as Cyclopogon inaequilaterus (Poepp. \& Endl.) Schltr. Photograph by Rudy Gelis.

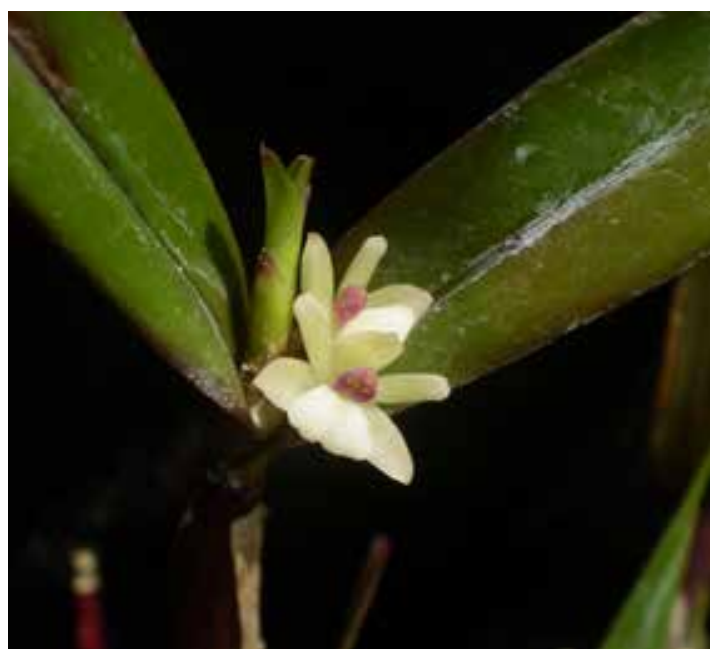

FIGURE 60. Scaphyglottis loretoenses Schltr. as Scaphyglottis graminifolia Lindl. Photograph by Dwittkower.

both brothers: Elleanthus carolii, Scaphyglottis antonii, Maxillaria koehleri, and Brassia koehlerorum (Fig. 72).

August Weberbauer (1871-1948; collected 19081948)

August Weberbauer (Fig. 73) was undoubtedly one of the most prominent members of Schlechter's South American network of orchid collectors. Weberbauer's contributions, especially in the field of systematic botany, became a cornerstone for our present understanding of the orchid flora of the Andes in general and Peru in particular. In the words of Rudolf

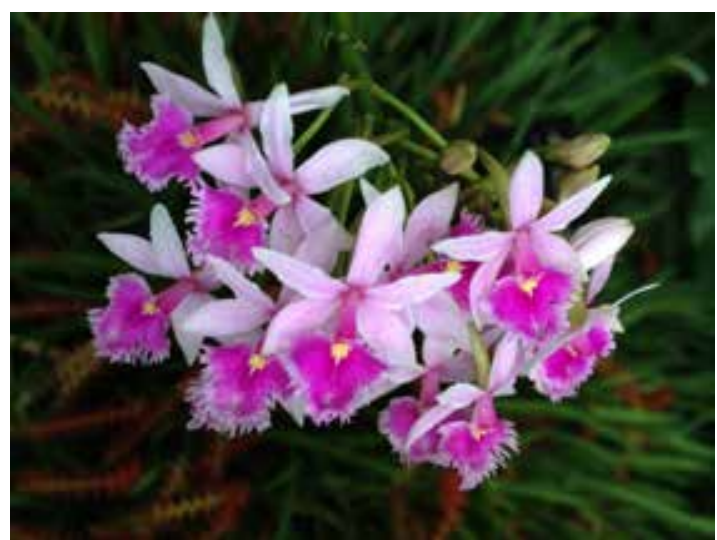

FIgURE 61. Epidendrum filomenoi Schltr. as Epidendrum calanthum Rchb.f. \& Warsz. Phograph by Olbrich Botanical Gardens, Madison, Wisconsin.

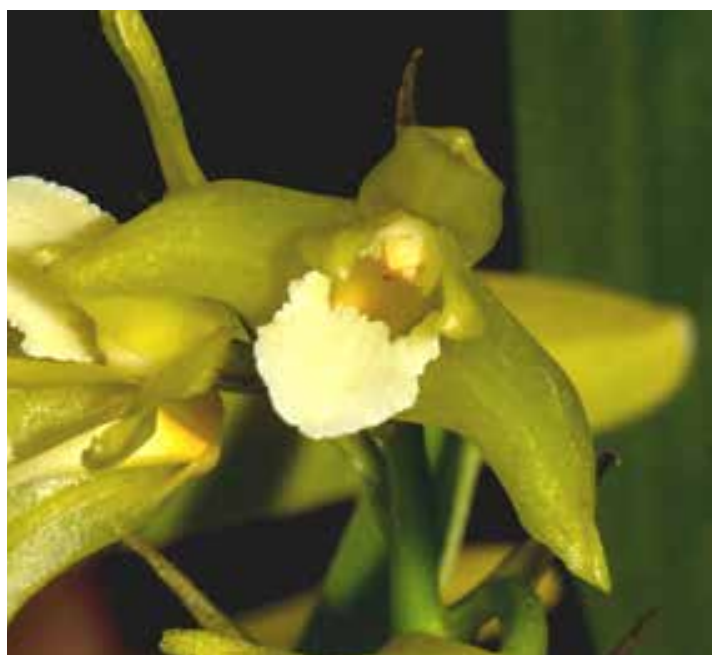

FIGURE 62. Xylobium filomenoi Schltr. as Xylobium foveatum

(Lindl.) G. Nicholson. Photograph by Quito Botanical Garden.

Schlechter, "with the arrival of A. Weberbauer began a new era in the exploration of the flora of Peru" (Schlechter 1921b: 11).

Weberbauer was born in Breslau, the son of mycologist Otto Weberbauer. He studied biology at the Universities of Berlin, Heidelberg, and Breslau. However, it was in his hometown that he received his doctorate in 1898.

August Weberbauer travelled to Peru for the first time in 1901, with the financial support of the Royal Prussian Ministry for Culture and the Prussian Academy of Sciences and the Peruvian government. He travelled around the country until 1905, sending his plant 


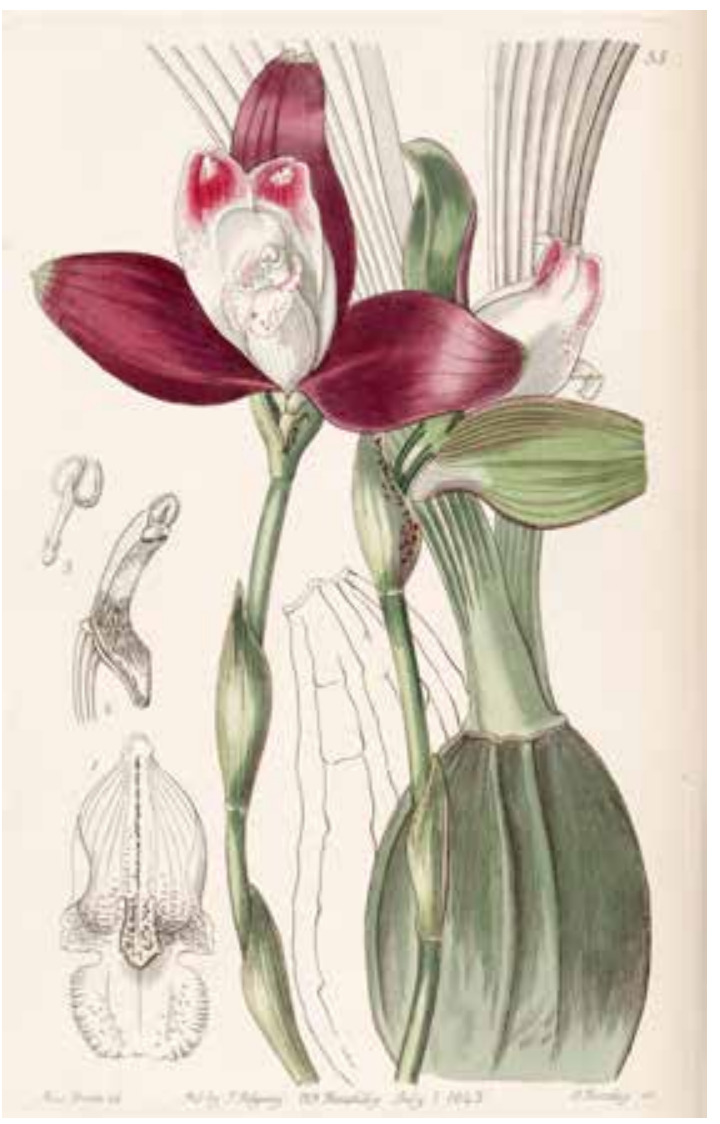

FIGURE 63. Lycaste filomenoi Schltr. as Lycaste macrophylla (Poepp. \& Endl.) Lindl. Edwards's Botanical Register, volume 29 (N.S. 6) plate 35.

collections of over 5200 specimens mostly to the herbarium of the Botanical Garden and Museum of Berlin-Dahlem. The first orchids collected by Weberbauer were described by Friedrich Kränzlin in 1905 under the title Orchidaceae Weberbauerianae in republica Peruviana lectae. Orchidaceae andinae, imprimis peruvianae Weberbauerianae followed in 1906, and a third publication, which included an important number of orchids collected by Weberbauer, Orchidaceae andinae, was published by Kränzlin in 1916.

After a short two-year interlude as director of the Botanical Gardens in Victoria, Cameroon (then a German colony), Weberbauer returned to Peru in 1908 to take charge of the Zoological and Botanical Gardens in Lima. Unable to return to Germany due to the outbreak of World War I, he resigned from the Gardens in 1914 to pursue more intensive research in the Peruvian Andes.

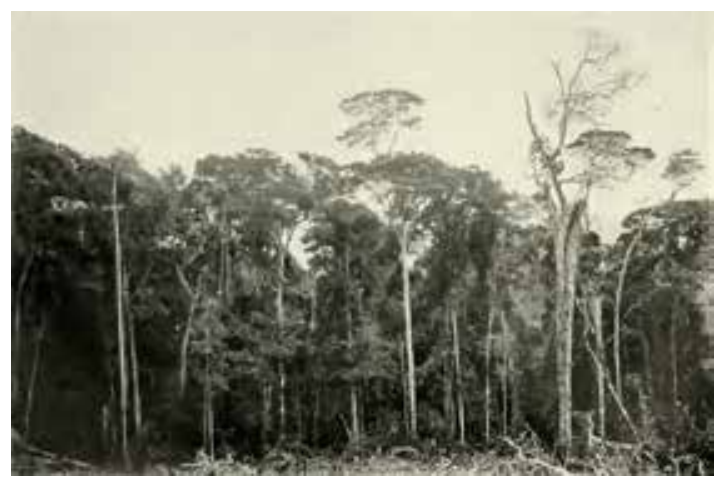

FIgURE 64. Forest above La Merced, Chanchamayo. Photograph by A. Weberbauer (1911), plate XXVII.

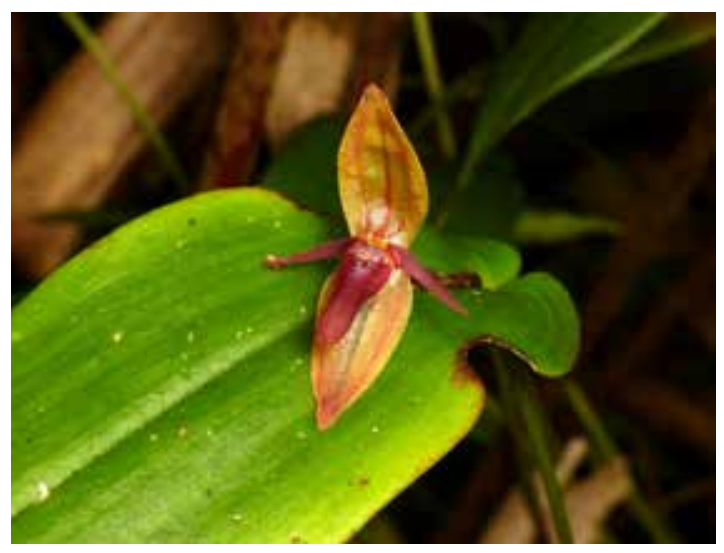

FIgure 65. Pleurothallis chanchamayoensis Schltr. As Pleurothallis bivalvis Lindl. Photograph by Andreas Kay.

During this period, in 1911 he published his most important work, Die Pflanzenwelt der peruanischen Anden (= 'The Vegetation of the Peruvian Andes') (Fig. 74-75).

Between 1917 and 1920, financial difficulties forced him to occasionally work for a mining company in the province of Huaura and occupy teaching posts at the Institute of Lima and the German 'Alexander von Humboldt' high school. However, he had by then already decided to remain in Peru for the remainder of his life. Rudolf Schlechter published his work on the orchid flora of Peru (Schlechter 1921b), based mainly on Weberbauer's collections in the Andes.

In 1922, Weberbauer was appointed to the chair in pharmaceutical botany at the Universidad Mayor de San Marcos, which he held for ten years. During the years 1925 to 1927 and 1929, he travelled across the Andes, studying the flora and collecting plants (Schuhmacher 


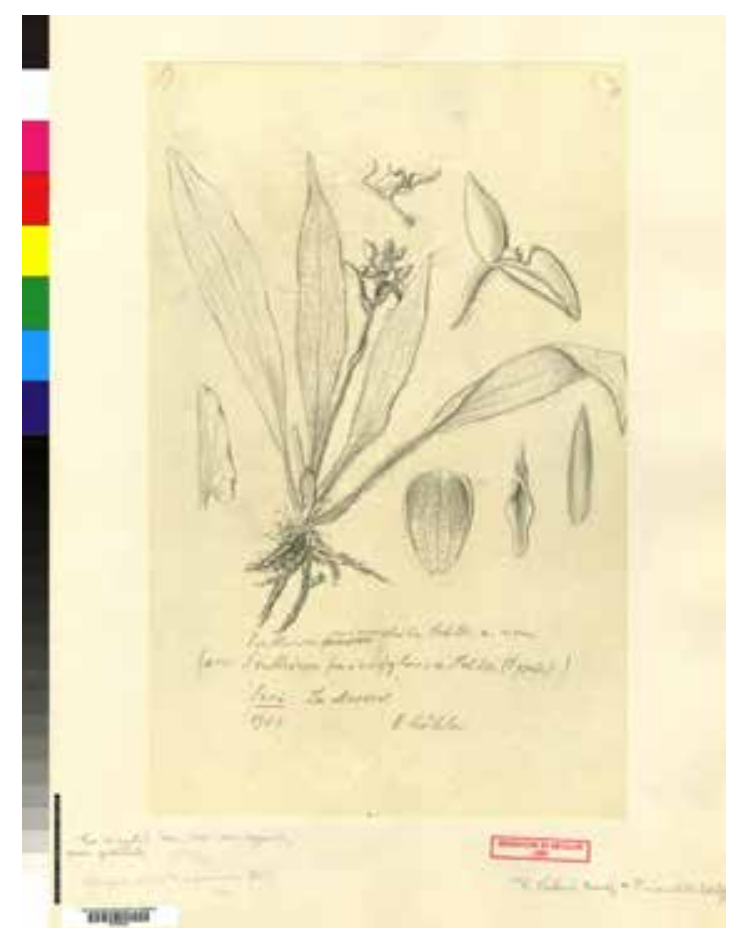

Figure 66. Ponthieva microglossa Schltr. Drawing of type. Courtesy of Harvard University Herbaria \#001093544.

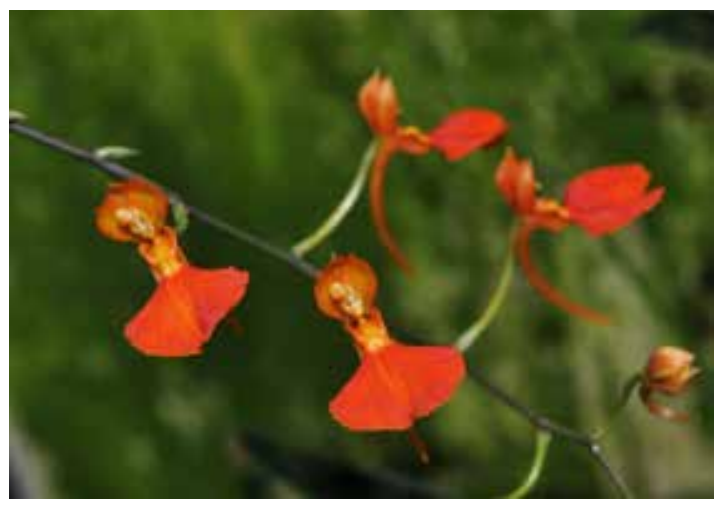

FIGURE 68. Neokoehleria peruviana Schltr. as (= Comparettia peruvioides M.W.Chase \& N.H.Williams). Photograph by Brent Baker.

\& Wolff 2001-2001: 7-9). These excursions were made possible due to his friendship with Francis Macbride, the director of the 'Flora of Peru' program of the Field Museum for Natural History in Chicago (Baca de Garcia 1949). An extensive collection of Weberbauer's specimens, among them many orchids, are, therefore today, part of the Field Museum's herbarium.

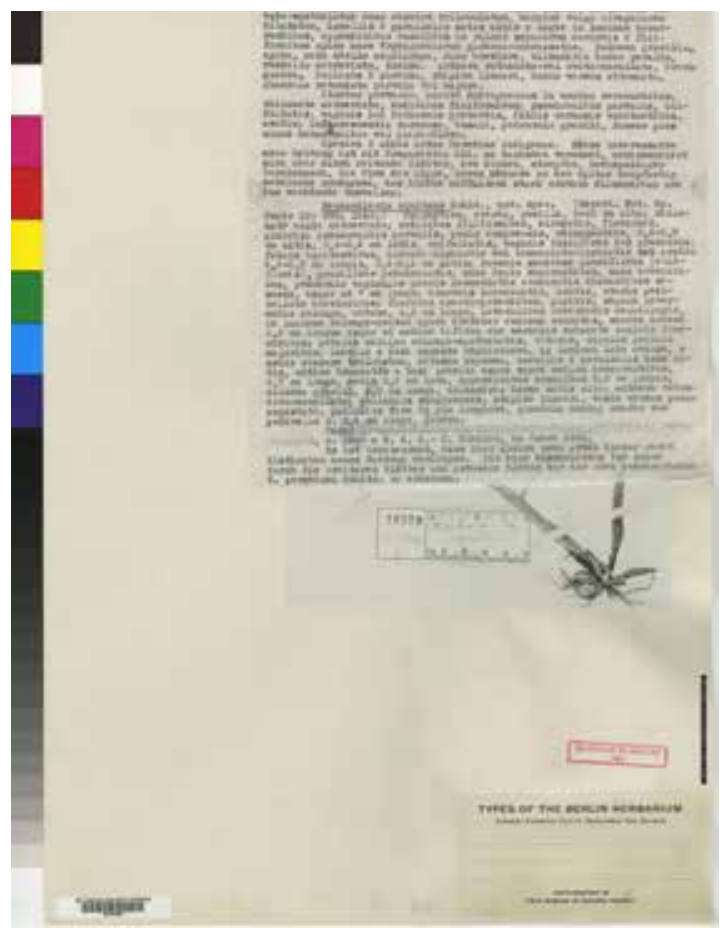

FIgURE 67. Photograph of the type of Neokoehleria equitans Schltr., and original description by Schlechter. Courtesy of Oakes Ames Orchid Herbarium, Harvard University.

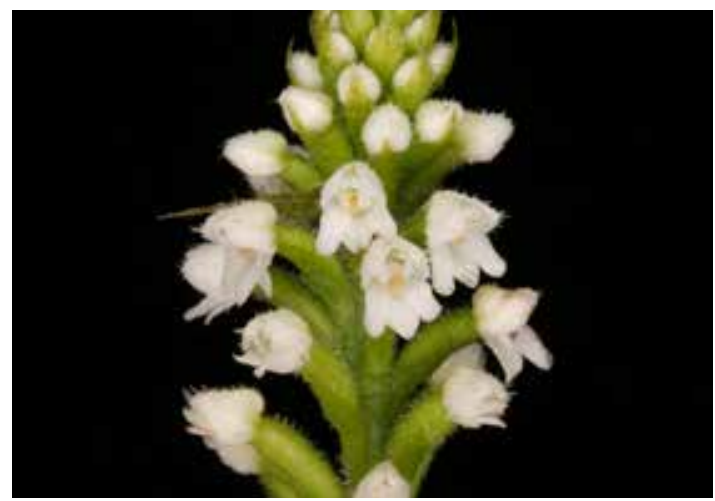

FIgURE 69. Cranichis koehleri Schltr. as Cranichis fertilis (F.Lehm. \& Kränzl.) Schltr. Photograph by Lourens Grobler.

Weberbauer travelled through Bolivia, Argentina, and Chile in 1928 and in 1929 to Germany to study his own specimens at the Berlin herbarium. After returning to Peru in 1930, he became head of the Botany Department of the University of San Marcos and remained in this position until the end of his life. During these years, he published a phytogeographical map of Peru 


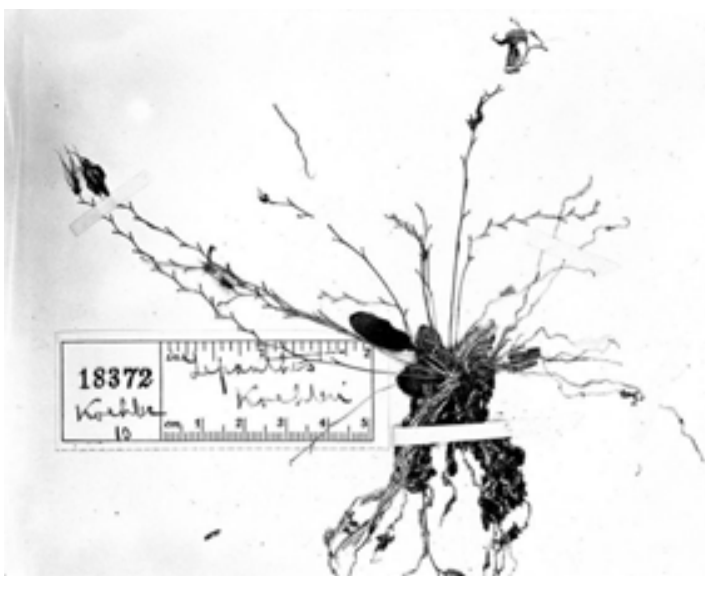

FIgURE 70. Photograph of type of Lepanthes koehleri. Courtesy of Field Museum of Natural History \# F0BN018372.

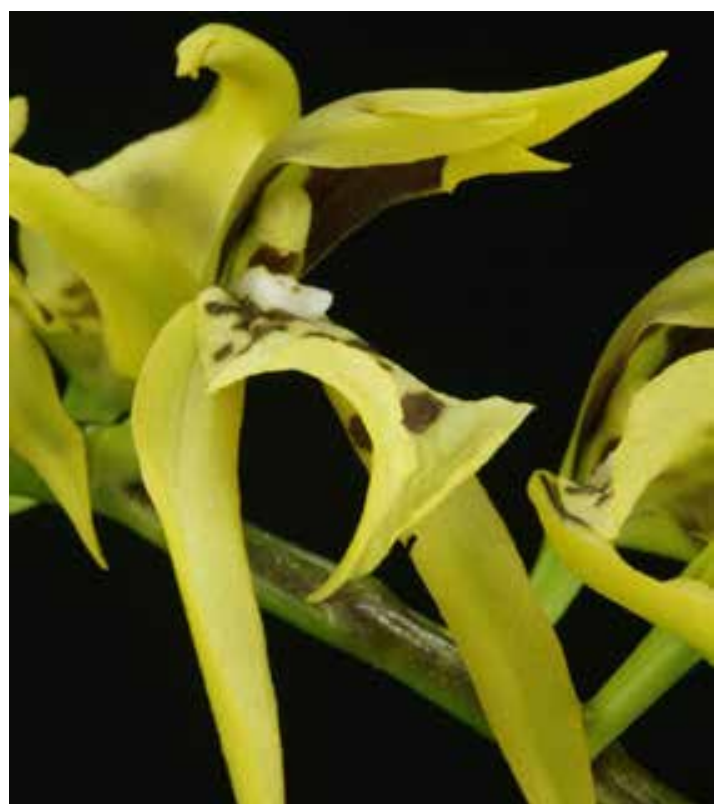

FIGURE 72. Brassia koehlerorum Schltr. Unknown photographer.

and research on various aspects of the Andean vegetation, particularly plant distribution studies, among them his well-known Phytogeography of the Peruvian Andes (Weberbauer 1936).

On January 16, 1948, at his funeral, he received the 'Orden del Sol del Perú' (= 'Order of the Sun of Peru') for his scientific achievements. In addition, the cactus genus Weberbauerocereus was named by Curt Backeberg in his honor.

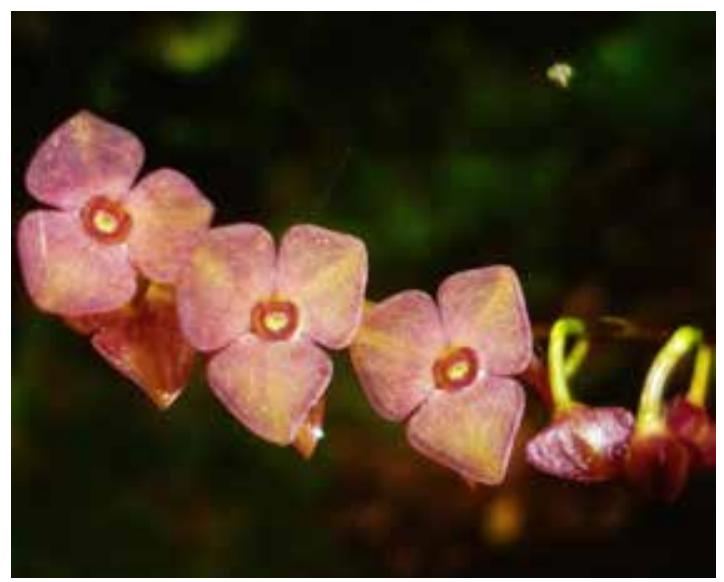

FIGURE 71. Stelis koehleri Schltr. (=Stelis superbiens Lindl.) Photograph by Luis Diego Arias.

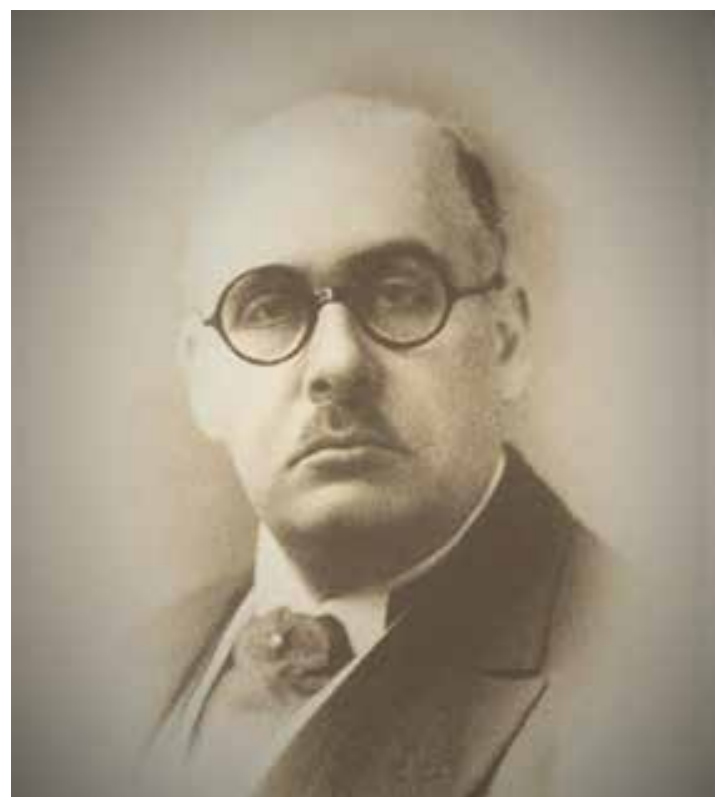

FIgURE 73. August Weberbauer (1871-1948). Photograph by José de la Riva Agüero. Archives of Rudolf Jenny.

Between 1905 and 1916 Fredrich Kränzlin described over 76 new species of orchids collected by Weberbauer. Finally, in 1921, Schlechter described 85 new species collected by Weberbauer (Schlechter 1921b). Of these, we will limit our list to a small selection, naming especially those species named in honor of Weberbauer by Kränzlin and Schlechter. By Kränzlin: Bulbophyllum weberbauerianum, Cochlioda weberbaueriana, Elleanthus weberbauerianus (Fig. 76), Epidendrum weberbauerianum 


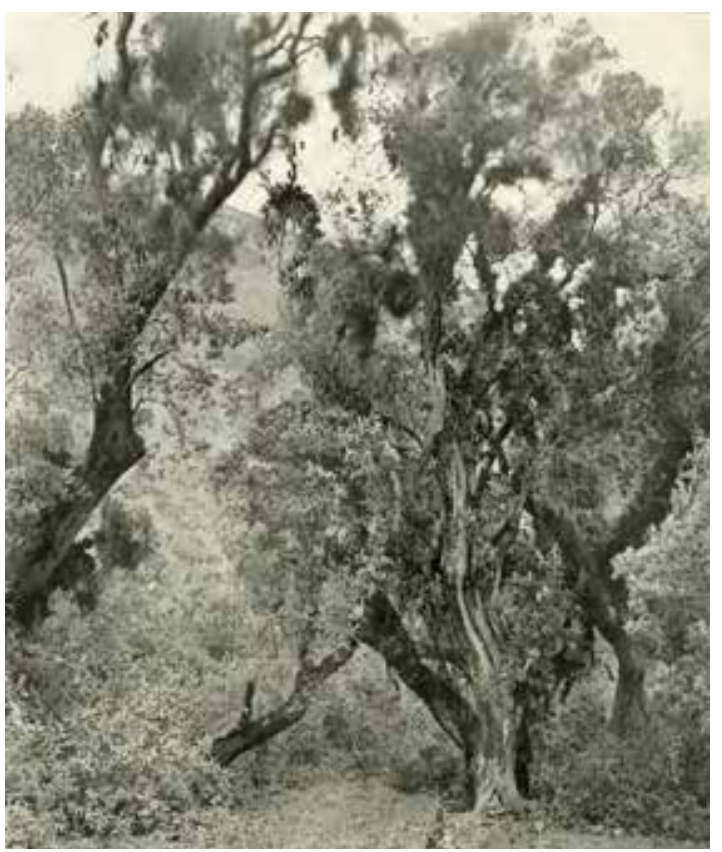

FIGURE 74. Forest of Buddleia incana R. \& P. in Conin, valley of Puccha. Photograph by A. Weberbauer (1911), plate XI.

(Fig. 77), Liparis weberbaueriana, Oncidium weberbauerianum, Ornithidium weberbauerianum, Pterichis weberbaueriana, Schomburgkia weberbaueriana (Fig. 78), Spiranthes weberbaueri, and Vanilla weberbaueriana. By Schlechter: Aa weberbaueri, Masdevallia weberbaueri (Fig. 79), Maxillaria weberbaueri, Pelexia weberbaueri, Ponthieva weberbaueri, and Stelis weberbaueri.

We assume that Weberbauer was acquainted with Koehler from two collections by Weberbauer in his early years in Peru, Lanium peruvianum Schltr. and Trigonidium peruvianum Schltr., both collected in La Merced, while he was likely a guest at the Koehler's 'hacienda'.

Weberbauer's specimens can be found in many of the world's herbaria, such as the Botanical Museum in Breslau, Poland, Geneva, Field Museum of Natural History in Chicago, Harvard, Kew, and Paris.

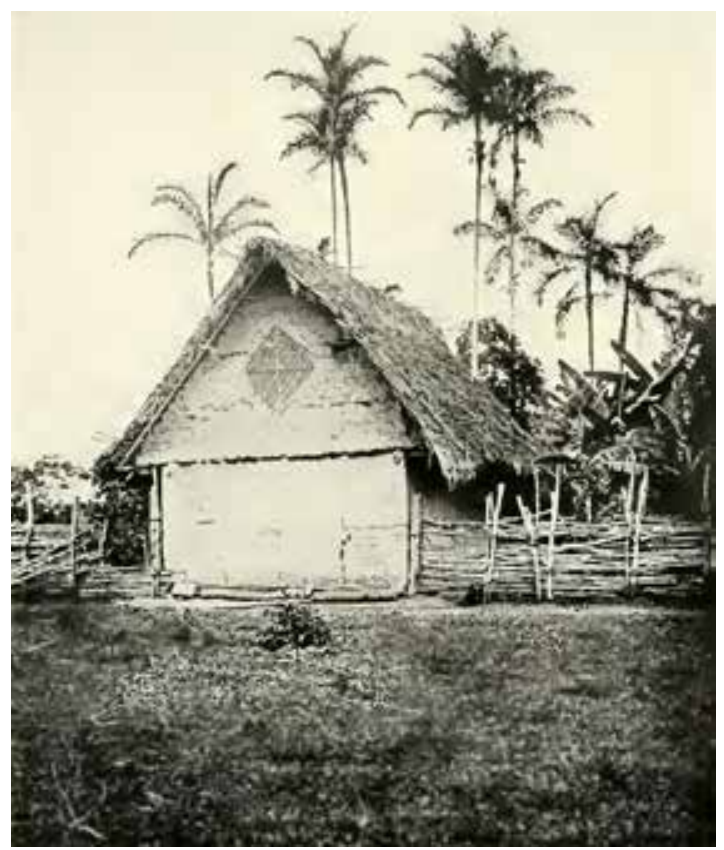

FIgURE 75. Indian dwelling near Moyobamba. Photograph by A. Weberbauer (1911), plate IIa.

The next and last chapter will relate to Schlechter's network in Bolivia and the other, mostly subtropical South American countries: Argentina, Chile, Paraguay , and Uruguay. The pattern will remain the same: brief geographical and historical outlines of the countries and their orchid history, followed by short biographical notes on the most important orchid collectors directly or indirectly related to Schlechter.

Acknowledgements. To Delsy Trujillo for invaluable information about Dr. Serafín Filomeno and Eugen Koehler. To the curators of AMES, F, K, and M herbaria for their kind permission to reproduce the herbarium images. And, as always, many thanks to Mark Budworth, for his philological revision of the text.

\section{LITERATURE CITED}

Acosta-Solís, M. (1968). Naturalistas y Viajeros Científicos que han contribuido al conocimiento Florístico y Fitogeográfico del Ecuador. Instituto Ecuatoriano de Ciencias Naturales, contribución $\mathrm{N}^{\circ}$ 65: 35-36.

Alves Milho, M.R. (2019). Biografía del Dr. Serafín Filomeno Peña. Unpublished manuscript.

Arosemena, A. (2017). El Ecuador y sus orquídeas: Contribución al conocimiento del desarrollo de la orquideología del Ecuador. Ecuador: Guayaquil Vivir S.A.

Baca de García, O. (1949). Obituary - August Weberbauer. Proceedings of the Linnean Society of London, $161^{\text {st }}$ Session (1948-49), 253. 

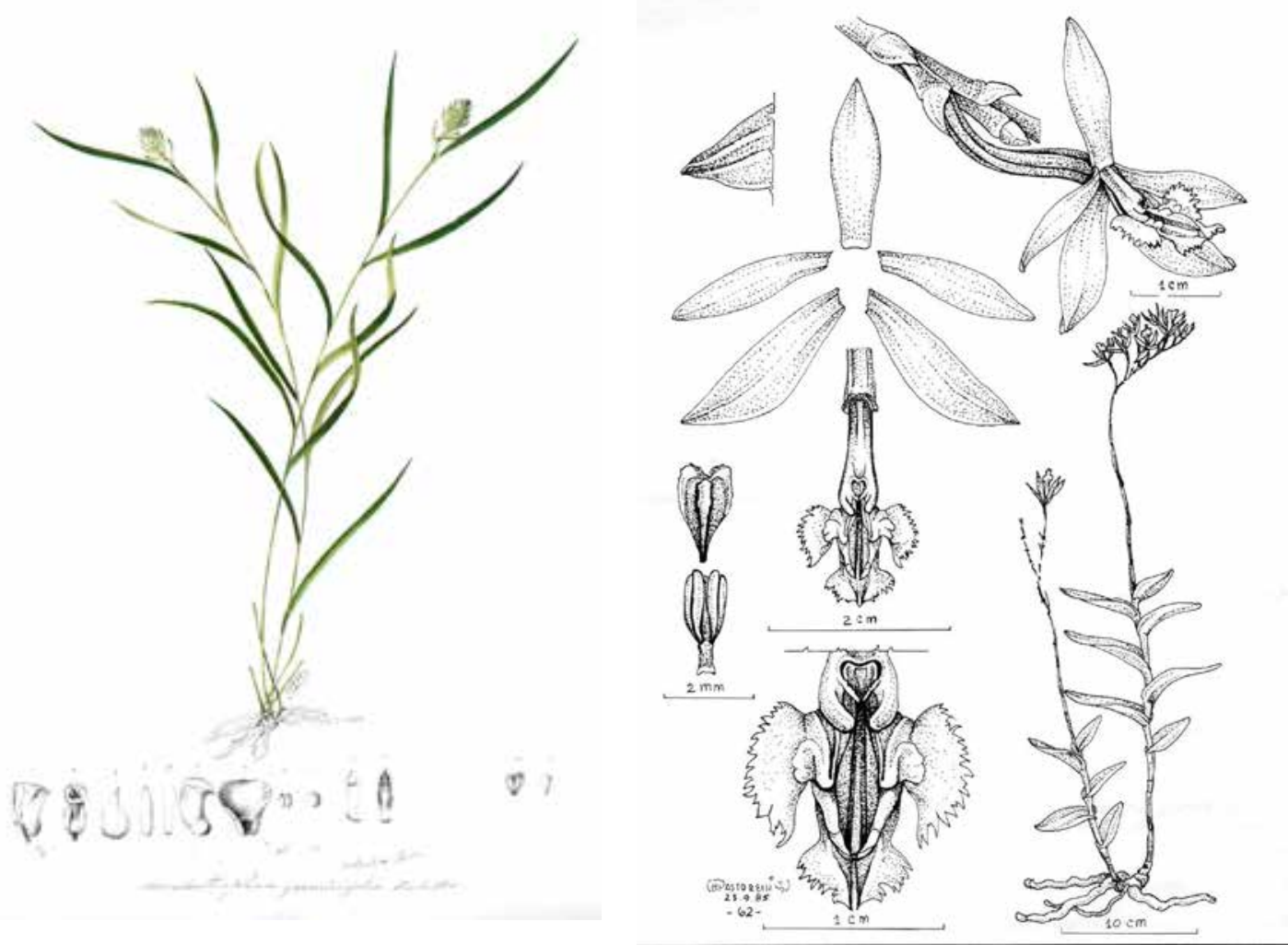

FIgURE 76. Elleanthus weberbauerianus Kränzl. As Elleanthus graminifolius (Barb.Rodr.) Løjtnant. In Iconographie des Orchidees du Brésil.

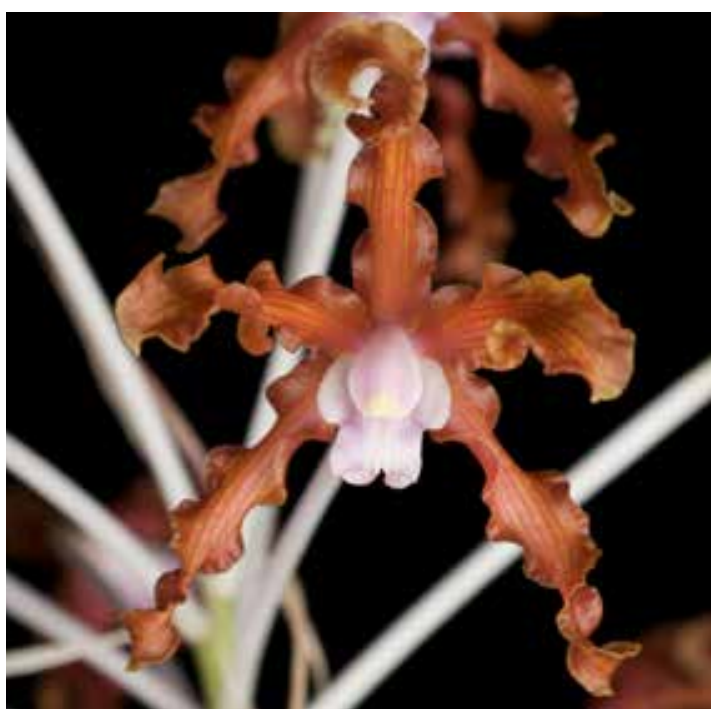

FIgURE 78. Schomburgkia weberbaueriana Kränzl. as Laelia weberbaueriana (Kränzl.) C.Schweinf. Photograph by Eric Hunt.

FigURE 77. Epidendrum weberbauerianum Kränzl. Drawing by Pastorelli in Icones Orchidacearum Peruviarum, Plate 254, 1995.

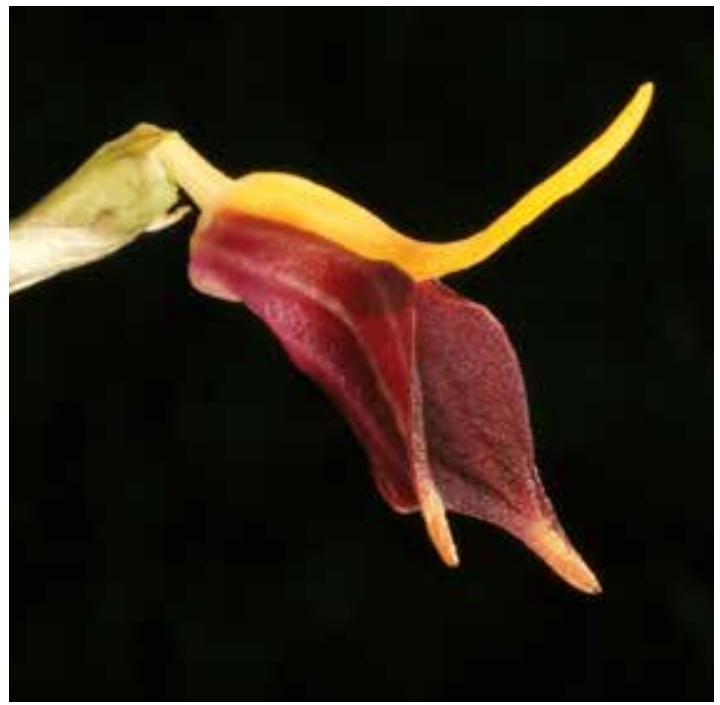

FIGURE 79. Masdevallia weberbaueri Schltr. Unknown photographer. 
Baldini, R. M. \& Guglielmone, L. (2012). Historical botanical collections in Latin America: the Italian contribution in the XIX century. Webbia, 67(1), 3-22.

Bentham, G. (1839). Plantae Hartwegianae: imprimis mexicanas adjectis nonnullis Grahamianis enumerat novasque describit. London: G. Pamplin.

Briosi, G. (1914). Cenno sopra Luigi Sodiro. Atti, Ser. 2, vol. 14. Italy: Universitá de Pavia, Istituto Botánico.

Dávalos, L. (1977). Contribución del Padre Luis Mille S. J. a la Botánica del Ecuador y presentación de su obra inédita. Revista de la Universidad Católica, 5(16). Quito: Pontifica Universidad Católica del Ecuador.

Eggers, Baron H. F. A. (1876). St. Croix’s Flora. Videnskabelige Meddelelser, Kjфbenhavn, 38, 33-158.

Eggers, Baron H. F. A. (1879). The Flora of St. Croix and the Virgin Islands. Washington D.C.: Government Printing Office. Godley, E. J. (1970). Botany of the Southern Zone - Exploration, 1847-1891 [W. Lechler]. Tuatara, 18(2), 69-70.

González, G. (2020). Interview with the journal La Revista, El Universo. Guayaquil, 3 May.

Herrera, F.L. (1937). Las Orquídeas de la Provincia de Moyobamba, colectadas por el Dr. Serafín Filomeno. Boletín de la Sociedad Geográfica de Lima, 55(4), 212-216.

Herrera, F. L. (1937b). Catálogo alfabético de los nombres vulgares y científicos de plantas que existen en el Perú. Revista del Museo Nacional de Lima, 6(02), 296-358.

Hooker, W. (1835). Narrative of a Journey to Payta. Companion to the Botanical Magazine, 1, 65-80.

Humboldt, A. \& Bonpland, A. (1805). Essai sur la géographie des plantes: accompagné d'un tableau physique des régions équinoxiales, fondé sur des mesures exécutées, depuis le dixième degré de latitude boréale jusqu'au dixième degré de latitude australe, pendant les années 1799, 1800, 1801, 1802 et 1803. Paris: Levrault, Schoell et Compagnie, Libraires.

Humboldt, A., Bonpland, A. Kunth, C. S. (1815-1825). Nova genera et species plantarum: quas in peregrinatione ad plagam aequinoctialem orbis novi collegerunt /descripserunt, partim adumbraverunt Amat. Bonpland et Alex. de Humboldt; ex schedis autographis Amati Bonplandi in ordinem digessit Carol. Sigismund Kunth accedunt tabulae aeris incisae, et Alexandri de Humboldt notationes ad geographiam plantarum spectantes. Paris: Greek-Latin-German Library.

Izaguirre, P. (2006). 100 años de historia de la botánica en la Facultad de Agronomía de la Universidad de la República. Conferencia dictada en la Facultad de Agronomía el 13 de noviembre de 2006. Montevideo, Uruguay.

Jameson, S. W. (1865). Synopsis plantarum aequatoriensium: exhibens plantas praecipue in regione temperata et frigida crescentes, secundun systematam naturalem descriptas viribus medicatis et usibus oeconomicis plurimarum adjectis. Quito: Juan Pablo Sanz.

Jørgensen, P. M., Ulloa, C., Pedersen, H. B. \& Luteyn, J. (1992). The Quito herbarium (QCA): 100,000 important collections from Ecuador. Taxon, 41, 52-56.

Jørgensen, P. M. \& León-Yañez, S. (eds.). (1999). Catalogue of the Vascular Plants of Ecuador. St. Louis: Missouri Botanical Garden.

Kraenzlin, F. (1905). Orchidaceae Weberbauarianae in republica Peruviana lectae. Repertorium specierum novarum regni vegetabilis, 12(1), 177-189.

Kraenzlin, F. (1906). Orchidaceae andinae. Botanische Jahrbücher fur Systematik, Pflanzengeschichte und Pflanzengeographie, XXXVII(5), 520-528.

Kraenzlin, F. (1916). Orchidaceae andinae, imprimis peruvianae Weberbauerianae. Botanische Jahrbücher fur Systematik, Pflanzengeschichte und Pflanzengeographie, LIV(1), 16-34.

Krauss, F. (1858). Obituary [Willibald Lechler]. Jahreshefte des Vereins für vaterländische Naturkunde in Württemberg, 14, 31-36.

Lehmann, F. C. (1891). Two new Coryanthes. The Gardeners' Chronicle, ser. 3, 10, 483.

Mansfeld, R. (ed.). (1929). Figuren-Atlas zu den Orchideenfloren der südamerikanischen Kordillerenstaaten. Repertorium specierum novarum regni vegetabilis, Beiheft, 57.

Mille, L. (1922). Nociones de Geografía Botánica aplicadas al Ecuador. Quito: Prensa Católica.

Ossenbach, C. (2020). A History of Orchids in South America. Volume I - Colonial times: from discovery to independence. Obereiffenberg, Germany: Koeltz Scientific Books.

Poeppig, E. F. \& Endlicher, S. L. (1835-1845). Nova genera ac species plantarum, quas in regno Chilensi Peruviano et in terra Amazonica: annis MDCCCXXVII ad MDCCCXXXII. Leipzig: F. Hofmeister.

Porter, P. (1909). Aloys Sodiro (notice biographique). Les Monde des Plantes, 11(61), 47.

Presl, C. B. (1830). Reliquiae Haenkeanae seu Descriptiones et Icones Plantarum quasin America Meridionali et Boreali, in Insulis Phillipinis et Marianis Collegit (Vol. I). Prague: J. G.Calve.

Renner, S. S. (1993). A History of Botanical Exploration in Amazonian Ecuador, 1739-1988. Smit hsonian Contributions 
to Botany, 82,4 .

Rimbach, A. (1897). Reise im Gebiet des oberen Amazonas. Zeitschrift der Gesellschaft für Erdkunde zu Berlin: zugl. Organ d. Deutschen Geographischen Gesellschaft, 360-409.

Ruiz, H. \& Pavón, J. (1798-1802). Flora Peruviana, et Chilensis, sive Descriptiones, et icones plantarum Peruvianarum, et Chilensium. Madrid: Gabriel de Sancha.

Schlechter, R. (1912). Orchidaceae novae et criticae, Decas XIX-XX. Repertorium specierum novarum regni vegetabilis, $10,385-397$.

Schlechter, R. (1914-1916). Orchidaceae novae et criticae, Decas XLII-XLVI. Additamenta ad Orchideologiam ecuadorensem I. Repertorium specierum novarum regni vegetabilis, 14, 114-133.

Schlechter, R. (1914-1916). Orchidaceae novae et criticae, Decas XLVII-XLVIII. Additamenta ad Orchideologiam ecuadorensem II. Repertorium specierum novarum regni vegetabilis, 14, 385-395.

Schlechter, R. (1915). Orchidaceae novae et criticae, Decas XLIII-XLVI [Orchids of Sodiro and Mille]. Repertorium specierum novarum regni vegetabilis, 14, 114-131.

Schlechter, R. (1917-1919). Orchidaceae novae et criticae, Decas XLII-XLVI. Additamenta ad Orchideologiam ecuadorensem III. Repertorium specierum novarum regni vegetabilis, 15, 49-59.

Schlechter, R. (1921). Die Orchideenfloren der südamerikanischen Kordillerenstaaten. III. Ecuador. Repertorium specierum novarum regni vegetabilis, Beihefte, $8,1-172$.

Schlechter, R. (1921b). Die Orchideenfloren der südamerikanischen Kordillerenstaaten. IV. Peru. Repertorium specierum novarum regni vegetabilis, Beihefte, 9, 1-182.

Schuhmacher, G. \& Wolff, G. (2001-2002). Inventar zum Nachlass August Weberbauer. Berlin: Ibero-Amerikanisches Institut.

Spruce, R. (1908). Notes of a Botanist on the amazon and Andes, vol. II. London: MacMillan \& Co.

Tafalla, J. J. (1989-1991). Flora Huayaquilensis sive descriptiones et icones plantarum Huayaquilensium secundum systema Linnaeanum digestae. Madrid: Real Jardín Botánico.

Weberbauer, A. (1911). Die Pflanzenwelt der peruanischen Anden in ihren Grundzügen dargestellt. In A. Engler \& O. Drude (eds), Die Vegetation der Erde, vol. 12. Leipzig: Wilhelm Engelmann.

Weberbauer, A. (1936). Phytogeography of the Peruvian Andes. Field Museum of Natural History. Botanical series, 13, 13-81.

Wolf, F. T. (1866). Beitrage zur Enwicklungsgeschichte der Orchideen-Blüthe. Jahrbücher für Wissensschaftliche Botanik, 4, 261-303.

Wolf, F.T. (1892). Geografía y Geología del Ecuador. Leipzig: F.A. Brockhaus.

\section{OTHER BIBLIOGRAPHICAL REFERENCES}

Adam, T. (ed.) (2005). Germany and the Americas, Culture, Politics and History, vol. 1 - ABC-CLIO. Santa Barbara, California.

Manning, S. (2010). Discovering New World orchids. Private edition. 